\title{
Recent progress and evolution of coolant usages in conventional machining methods: a comprehensive review
}

\author{
Gary Wong Ang Kui ${ }^{1}$ - Sumaiya Islam ${ }^{1} \cdot$ Moola Mohan Reddy ${ }^{1} \cdot$ Neamul Khandoker $^{2} \cdot$ Vincent Lee Chieng Chen $^{1}$
}

Received: 29 May 2021 / Accepted: 6 October 2021 / Published online: 25 October 2021

(c) The Author(s), under exclusive licence to Springer-Verlag London Ltd., part of Springer Nature 2021

\begin{abstract}
This paper reviews recent progress and applications of usage of cutting fluids in conventional machining processes. In addition to reviewing the various conventional and advanced cooling techniques during machining, the paper also discusses the use of minimum quantity lubrication (MQL) in several types on metals such as steel, aluminum, alloy, and titanium alloys. Due to the toxicity of conventional cutting fluid resulting in ecological problems, the demand for environmentally friendly cutting fluid is rising. Therefore, natural vegetable oil is chosen as potential replacement as an environmentally friendly cutting fluid which fulfills the important aspects of biodegradability and sustainability. Application of vegetable oil-based cutting fluids under MQL techniques are also discussed. Moreover, the potential of palm oil as biodegradable and environmentally friendly natural vegetable oil-based metal-working fluids in MQL are reviewed.
\end{abstract}

Keywords: Machining $\cdot$ MQL $\cdot$ Conventional cutting fluid $\cdot$ Vegetable oil

\section{Introduction}

Machining operations play an important role in the manufacturing industries nowadays. Through machining operations, desired dimensions, shapes, and surface finishes can be achieved via removal of workpiece materials in form of metal chips from the direct contact of cutting tools and workpiece. The process of excess material removal is known as plastic deformation of the workpiece surface, where almost $99 \%$ of energy fed to the cutting tool and these energies are converted into heat and frictions. When ferrous metals and other high-strength metals or alloys are machined, the temperature rises with the cutting speed and depth of cut and the tool strength decreases, leading to increase in tool wear and tool failure [1]. Machining at higher speed is more desirable for better product quality; however, higher temperature is produced. Therefore, cutting fluids are used during machining operations not only to cool down the cutting zone, so that the cutting tool and workpiece not only can be

Sumaiya Islam

sumaiya.islam18@gmail.com; sumaiya.islam@curtin.edu.my

1 Faculty of Mechanical Engineering, Curtin University Malaysia, CDT 250, 98009 Miri, Sarawak, Malaysia

2 School of Engineering and Technology, Central Queensland University, Melbourne, Australia kept at a controlled temperature, but also provide significant lubrication between the cutting tool and workpiece to reduce friction which improves overall machining performances in any machining processes [2-4].

To improve machinability of hard-to-machine metals like titanium and alloy metals, cutting fluids are introduced into conventional machining processes [6]. Cutting fluids or metal-working fluids (MWFs) allow removal of excess heat and improve the machinability and cutting tool's effective life through cooling of workpiece interface during machining processes [7-9]. Cutting tool wear can be reduced when overheating is prevented to maintain cutting tool sharpness which results in better surface finish in machining operations $[10,11]$. It also improves chip removal process from the tool-workpiece interface and prohibits built-up edge formation on the surface of the cutting tool. Before the introduction of cutting fluids, dry machining is the most common type of material removal process which allows cost-saving in terms of the eliminations of metal-working fluids. Conventional applications of cutting fluids such as flooded cooling, solid coolants, cryogenic cooling, and high-pressure coolant as shown in Fig. 1 are commonly used as cutting fluid delivery methods where large amounts of coolant are sprayed onto the cutting zone. However, excessive use of cutting fluids leads to several environmental hazards and health and safety issues which also subsequently increase the 
Fig. 1 Different types of cooling techniques [5]

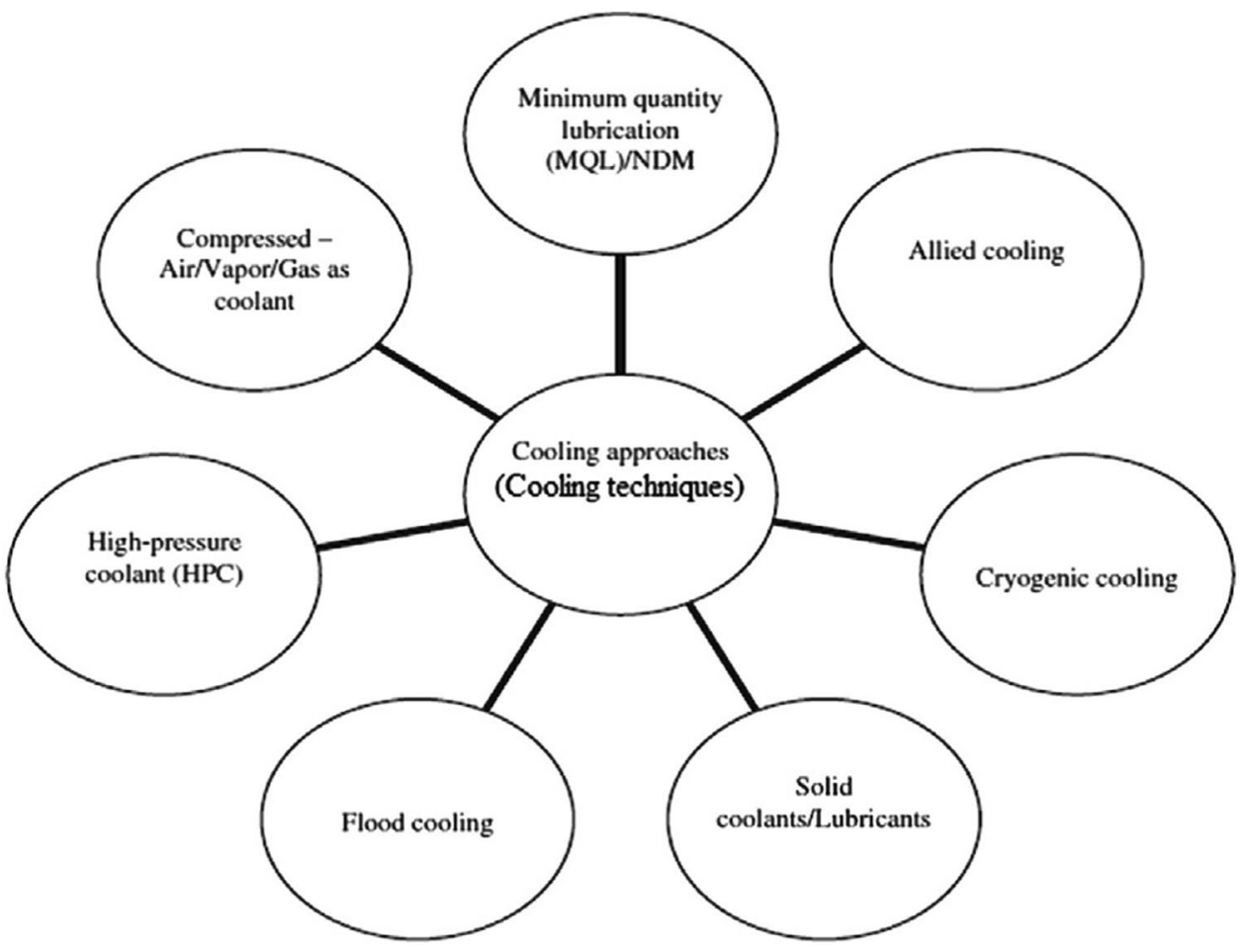

total costs of manufacturing industries [7]. Hence, minimum quantity lubrication (MQL) are introduced as an alternative cutting fluid delivery method during machining processes to minimize the amount of cutting fluid used to achieve "green" machining [12].

In the past several years, an effort has been made to perform more research on to study and improve machining with major focuses on the applications of MQL, and usage of vegetable oil-based cutting fluids in machining of difficultto-machine materials such as titanium alloys. Based on the graphical representation of research published by year as shown in Fig. 2, pioneering period can be seen in the first years between year 1998 and year 2008 where the published papers are very low, followed by a steady increase in published research papers from year 2009 all the way up to year 2020. There is a slight reduction of publication numbers between 2020 and 2021 which might be due to the COVID19 pandemic that limited the experimental research across the world. Based on the geographic distribution of the published research papers, researchers from India respond with the most publications at more than 264 , followed by China at 81, Brazil at 71, and Malaysia at 60 as seen in Fig. 3.
Fig. 2 Numbers of paper publications per year [13]

\section{Documents by year}

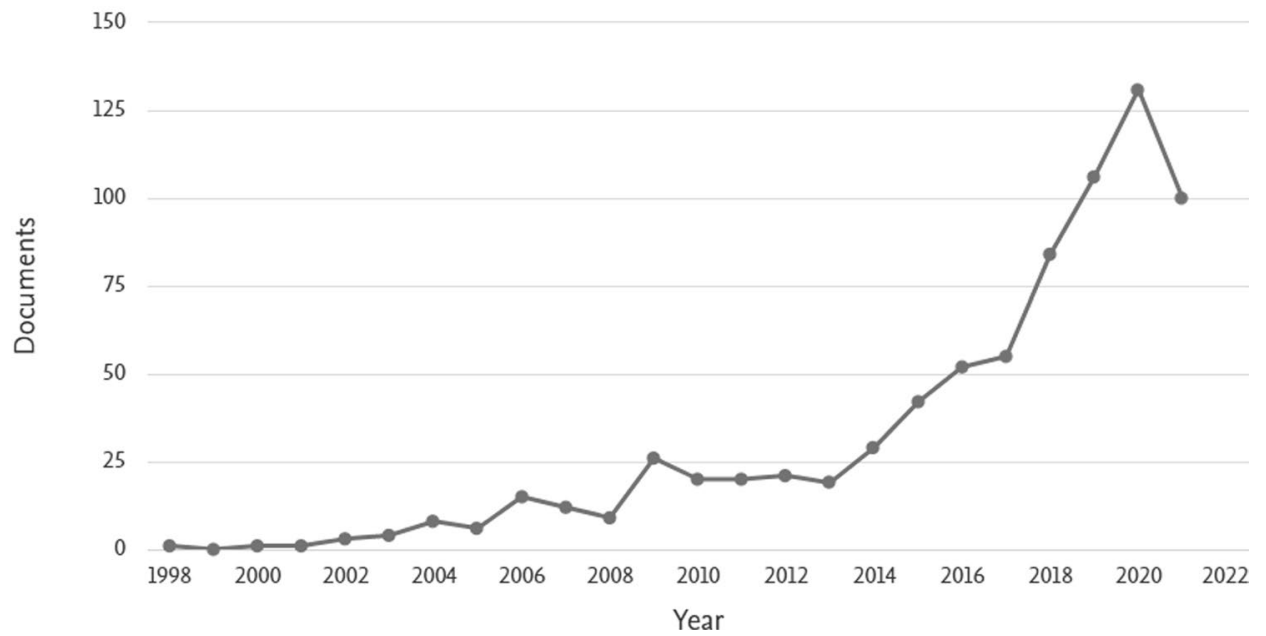


Fig. 3 Numbers of paper publications by country [13]
Documents by country or territory

Compare the document counts for up to 15 countries/territories.

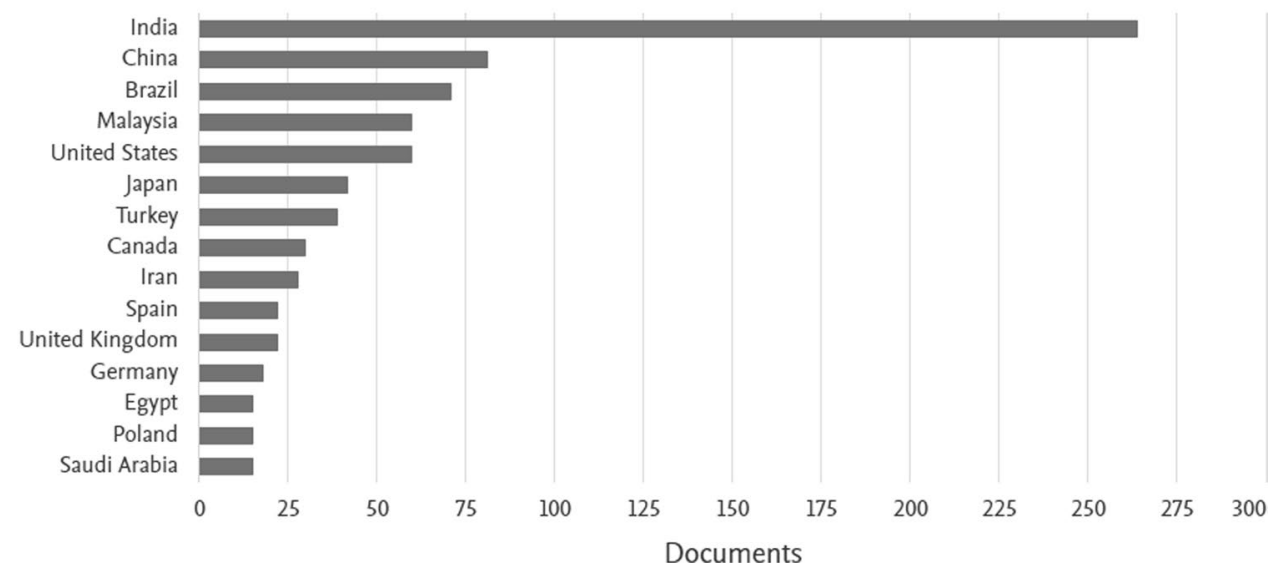

\section{Types of coolant delivery}

\subsection{Machining under dry condition}

Dry machining involves metal removal process with the absence of any metal-working fluids [14-17]. In dry machining, formation of built-up edge occurs when machining is carried out at lower cutting speed, high tool feed rate, and low rake angle. The development of higher cutting temperature at high machining speed often leads to poor surface finish and tool life due to thermal shock. Moreover, high cutting temperature leads to reduce the strength of the workpiece material, causing lower cutting forces at the cutting zone [18-20]. However, in some cases, dry machining is preferred for cost-saving and sustainability of the environment. An experimental setup for dry machining of stainless steel by Galanis et al. [21] is shown in Fig. 4.

In this study, cutting parameters such as cutting speed, feed rate, and depth of cut were varied to investigate the machining performances such as surface roughness and cutting temperature. They found that dry machining performed significantly better in terms of surface finish and tool life in comparison to wet machining. In more recent study, the influence of cutting fluid on tool performance of wet and dry drilling of carbon fiber-reinforced polymer (CFRP) was investigated and they found that dry drilling produced lower thrust force and longer tool life compared to wet cutting conditions as shown in Fig. 5. Dry drilling managed to produce mean circularity of $30 \mu \mathrm{m}$ across the tool life, in contrary of using cutting fluids produced the least effective circularity of $42 \mu \mathrm{m}$.

Moreover, another study was performed by Songmene et al. [23] on the effect of lubrication and machining condition on tool wear and tool life to find the machinability of tool steels. It is found that dry milling of the alloy improved

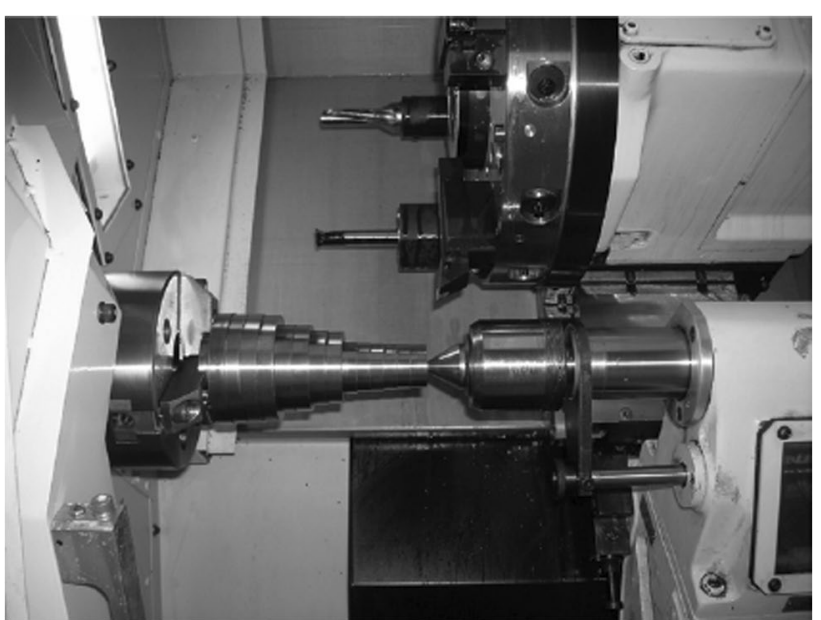

Fig. 4 View of dry machining for stainless steel turning [21]

tool wear and tool life over wet machining as shown in Fig. 6. They also concluded that dry milling of low hardness material can produce better tool life compared to harder materials, showing the sensitivity of dry machining conditions on material compositions over wet machining.

Revuru et al. [24] performed comparative studies on the performance of dry, flooded, and MQL machining with soybean vegetable oil-based cutting fluid using TiC/TiCN/TiNcoated carbide inserts in turning of 4140 steel. The authors found that feed rate is the most significant cutting parameters to influence the surface roughness while the cutting speed did not have any significant impact on the tool wear. Dry machining is involved to produce the best results in comparison to flooded or MQL machining which implement that the removal of cutting fluids can be achieved by selecting the suitable machining parameters and cutting tool materials. 


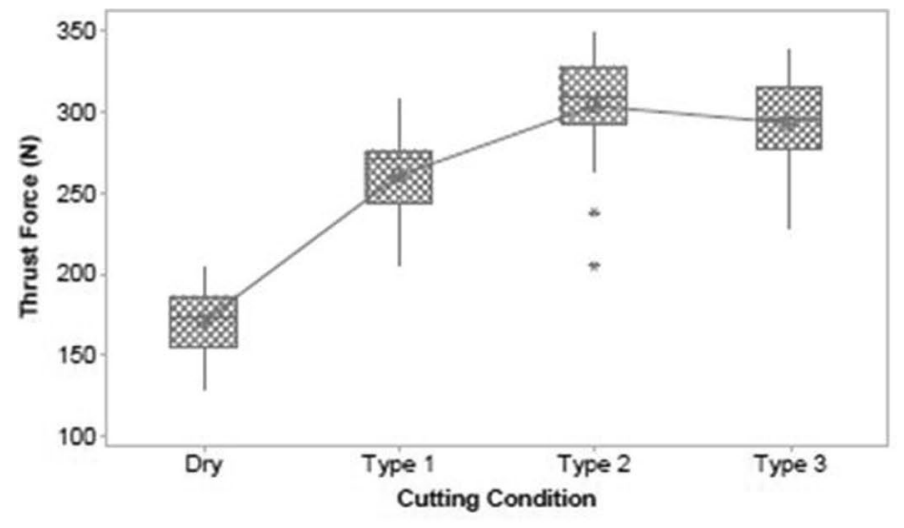

a)

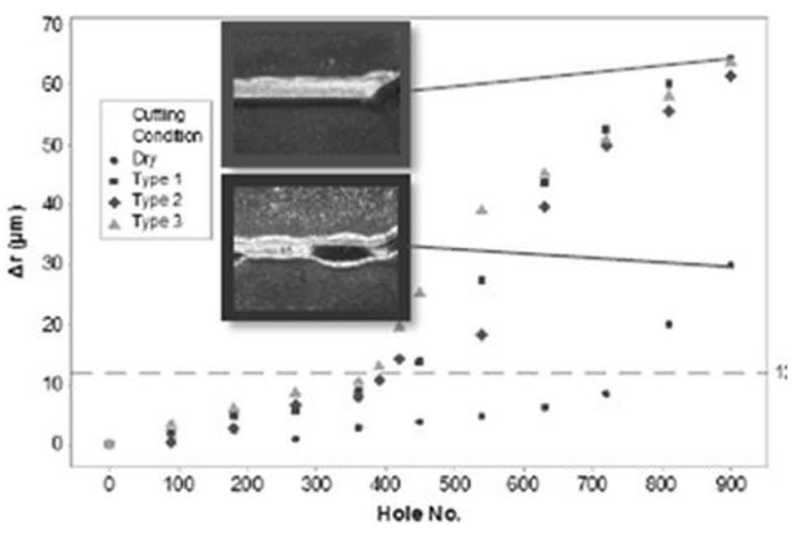

b)

Fig. 5 Machining performance comparison of $\mathbf{a}$ thrust force and $\mathbf{b}$ tool life between dry and wet machining of CFRP [22]

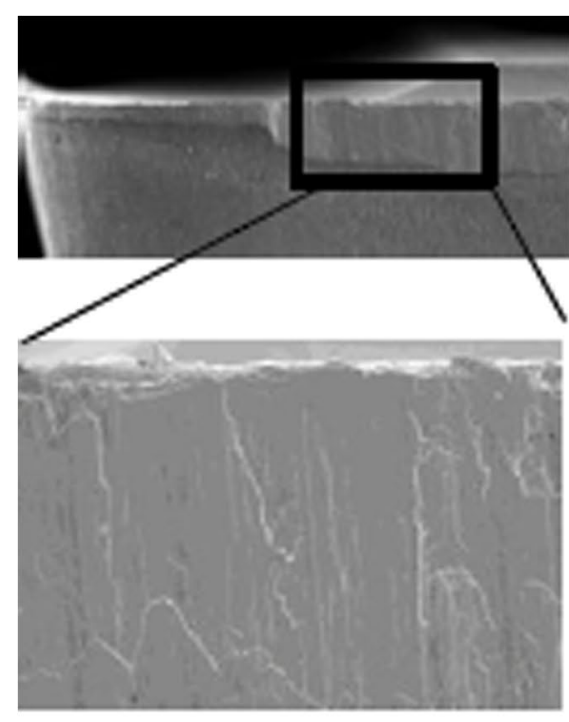

$\mathbf{a}$

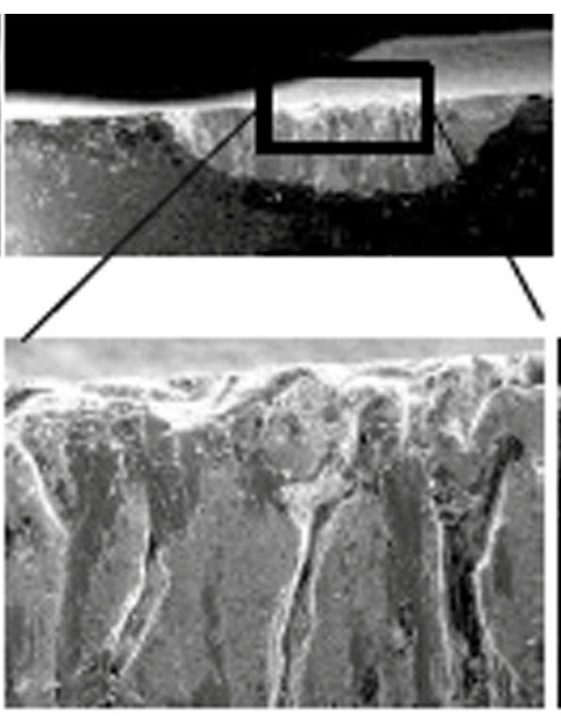

b

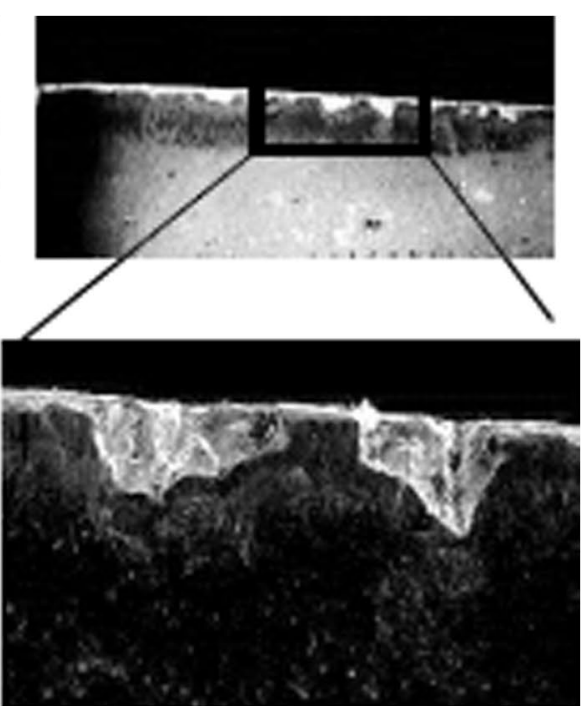

c

Fig. 6 Tool wear analysis on flank face of cutting inserts under a dry milling compared to wet milling in $\mathbf{b}$ and $\mathbf{c}$ [23]

\subsection{Machining under flooded cooling}

Flood cooling and MQL are two prominent fluid delivery techniques that can be applied to most machining processes. In flood cooling delivery, metal-working fluids are delivered out of a nozzle in the form of liquid jet to immerse the entire cutting zone which can be seen in Fig. 7.

Large volume of cutting fluids is dispersed at high flow rate at the cutting zone which completely covers the tool-workpiece interface [26-28]. Generally, in flooded cooling, the flow rates range from 10 to $225 \mathrm{~L} / \mathrm{min}$ based on the type of machining operations[29]. The large quantity of cutting fluids applied to the machining zone are able to remove the excess heat and provide lubrication. Flooded cooling machining has the advantage over dry machining of producing better surface finish and maintain better tool life [25]. Though there are some advantages of using flooded coolant, it has also various disadvantages. One of the disadvantages is to find sustainable ways of disposing contaminated cutting fluids with metal chips. The overall cost for this and its exposure to the machine operators need to be addressed to improve the sustainability of flood cooling methods in machining.

An experimental study and modeling is carried out by Sankar and Choudhury [30] on machining of microalloyed steel under dry, flooded, and MQL cutting fluid delivery methods. The authors found that the machining performance of flooded cooling in terms of surface roughness, tool wear, 


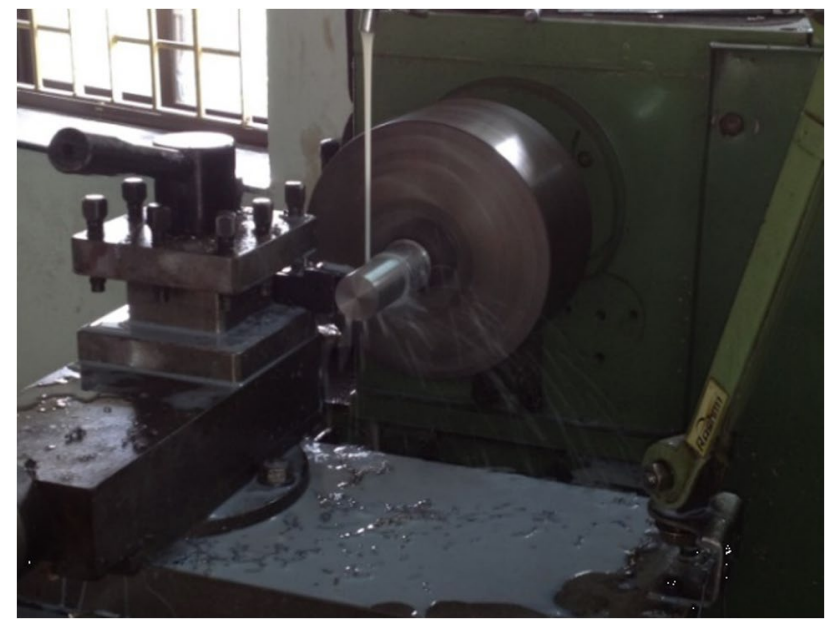

Fig. 7 View of wet machining [25]

and chip thickness were improved over dry machining. Senevirathne and Punchihewa [31] performed a comparison between the effect of dry cutting, flooded cooling, and MQL on tool life and surface roughness during the machining of P20 and D2 steel using coated carbide tools with emulsion cutting oil as cutting fluid. In their study, they concluded that MQL does not necessary always produce the best machining performance as shown in Fig. 8. The flooded cooling method improved the surface roughness and tool wear significantly in comparison to dry cutting and MQL.

Peng et al. [32] performed a study on the design and performance of internal cooling turning tool with microchannel structures on the machining of Inconel 718. They found that flood cooling was able to improve drilling force, cutting temperature, and surface roughness compared to dry drilling. Chen et al. [33] investigated the effect of cooling methods such as dry, flooded, MQL, cryogenic, and cryogenic MQL methods on the machining performances of betatype titanium-zirconium-niobium alloy (Ti-Zr-Nb alloy). Their research showed that flooded cooling had significant improvement in terms of drilling force, surface roughness, microhardness, and tool flank wear in comparison to dry drilling process as shown in Fig. 9.

\subsection{Machining under high-pressure coolant}

High-pressure coolant delivery (HPC) system pumps coolant at high pressure ranging from 300 to 1000 PSI which allows improvements in penetration of cutting fluids at the tool-workpiece interface and provide better cooling and lubrication effects [34]. A photographic view of high-pressure coolant delivery system is shown in Fig. 10.

HPC can provide an alternative cooling during machining, especially during the process of turning operation where coolants are delivered through specialized cutting tool insert with built in nozzles as shown in Fig. 11. During the machining process, a layer of steam forms on the surface of the cutting tool and workpiece known as "vapor barrier" which acts as a heat insulator to provide cooling on the tool-workpiece interface [37]. High-pressure coolant supply also tends to lift the chips from the workpiece quickly. Therefore, it reduces contact length and area between the tool and metal chips resulting into improved tool life.

Moreover, HPC can penetrate the vapor barrier, causing the formation of a "hydraulic wedge" which results in cooling and quenching of the metal chips. Plastic deformation would occur, forcing the metal chips to slide over the tool rake face and removed from the workpiece as visualized in Fig. 12.

Yusuf Kaynak et al. [35] performed a study on comparison of flood cooling, MQL, and high-pressure coolant on the machining and surface integrity of titanium alloy. They found that high-pressure coolant was able to provide significant improvement on machining performance such as surface roughness of titanium alloy compared to flooded cooling and MQL. Tamil Alagan et al. [37] investigated the effects of high-pressure cooling in flank and rake faces of WC tools in turning of 718 alloy and showed that at higher pressure coolant delivery improved the tool life and overall machining performances. The study of influence of cutting fluid flow under high-pressure coolant turning using internally cooled cutting insert was performed by Fang and Obikawa [39]. They concluded that the increase of coolant pressure enhanced the resistance against flank wear of the cutting inserts as shown in Fig. 13. Similar results are also
Fig. 8 Mean tool wear and surface roughness with dry, flooded, and MQL methods [31]
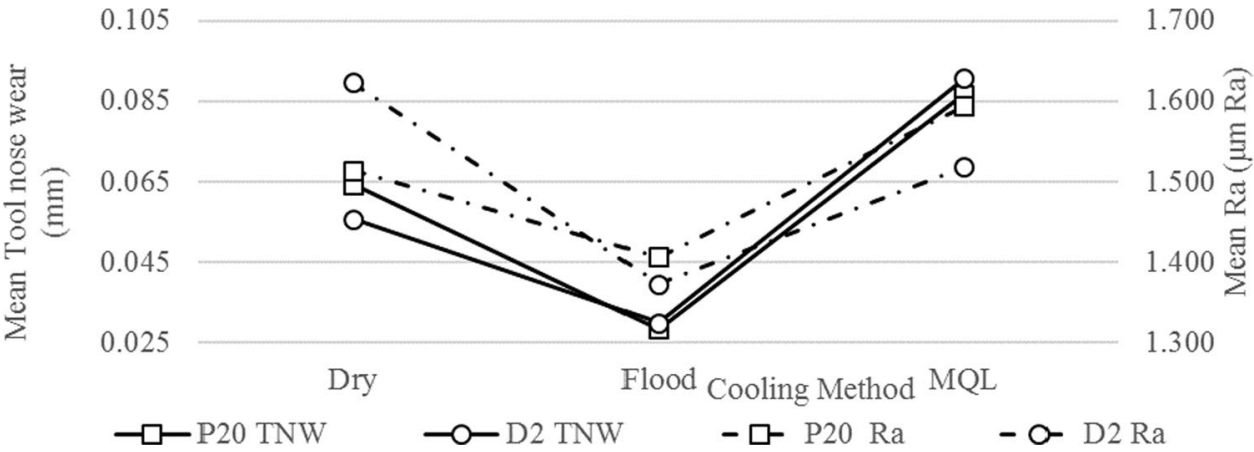

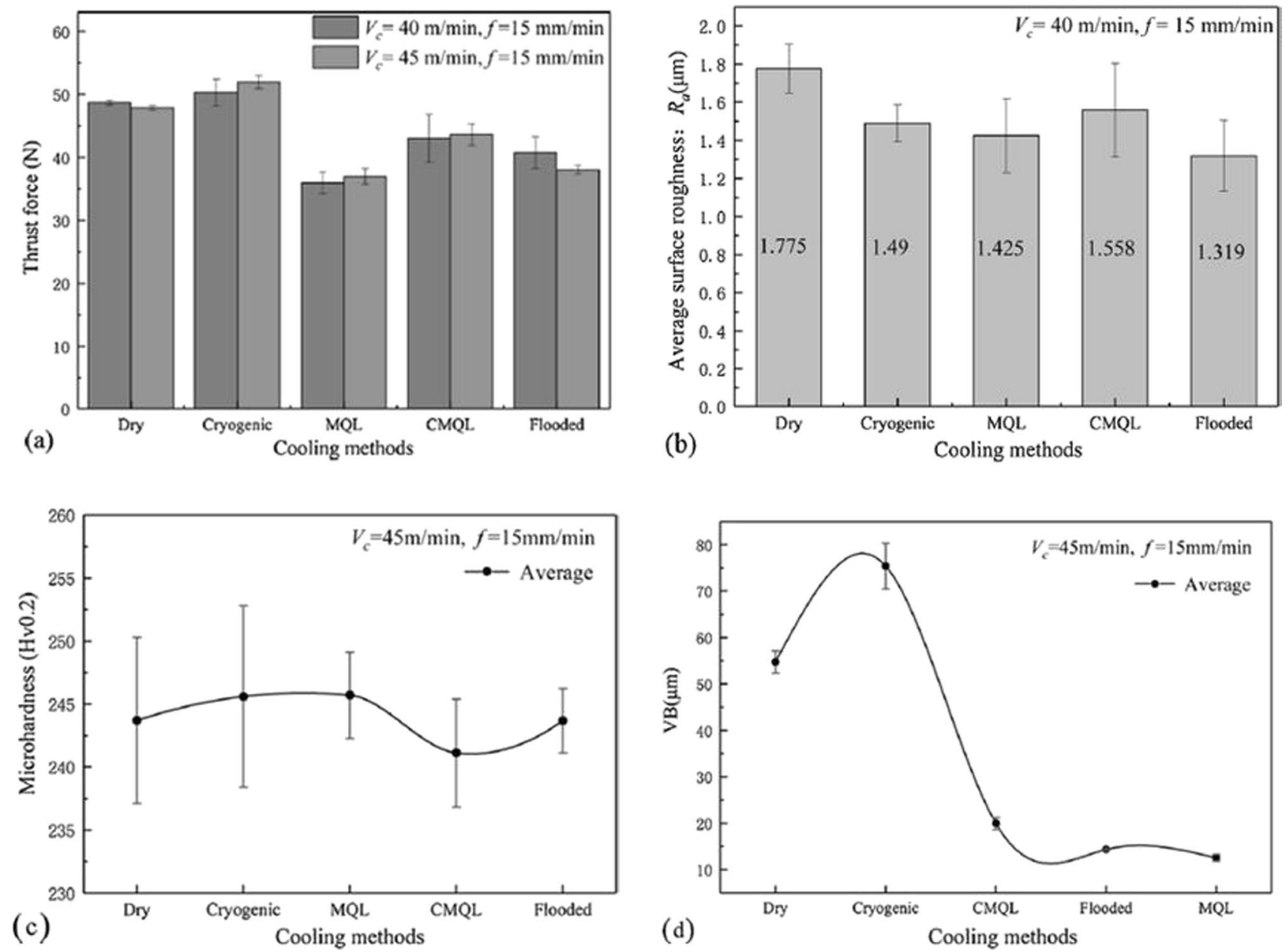

Fig. 9 Machining performance comparison between dry, cryogenic, cryogenic MQL, flooded, and MQL methods for $\boldsymbol{a}$ thrust force, $\boldsymbol{b}$ surface roughness, $\boldsymbol{c}$ microhardness, and $\boldsymbol{d}$ tool flank wear [33]

observed in terms of surface roughness and tool life even at critical pressure as shown in Fig. 14.

Nasr et al. [40] used high-pressure jet cooling in nickelbased superalloy turning at different level of cutting speeds and feed rates and found that 70 bar of coolant delivery pressure was the optimum pressure to produce best tool life, tool wear, and material removal rates along with selected cutting parameters.

\subsection{Machining under solid coolant/lubricant}

Solid lubricant is an attempt of lubrication and cooling using solid materials in machining which consisted of organic and inorganic compounds or metal flakes. There are variety of materials with the inherent lubricating capability which can be used as solid lubricant such as molybdenum disulfide $\left(\mathrm{MoS}_{2}\right)$, graphite, and polytetrafluoroethylene [41]. Solid lubricant is usually delivered in dry powder form which contains lubricant additives due to the nature of their crystal lattice structures arranged in layers for improvement in terms of friction and minimizing tool wear under extreme machining operations [42-44]. Solid lubricants were able to withstand extreme temperature due to their high chemical inertness and low volatility. Moreover, as shown in Fig. 15, solid lubricant consisting of dry powder contains lamellar structures which are parallel to the direction of the motion causing the lamella layers to shear resulting in lower friction [45].

In related study, machining performance of molybdenum disulfide $\left(\mathrm{MoS}_{2}\right)$ nanolubricant during CNC milling operation of aerospace grade aluminum was investigated by Rahmati et al. [46]. They found that using $1 \mathrm{wt} \%$ of $\mathrm{MoS}_{2}$ nanolubricant at a pressure of 4 bar and $30^{\circ}$ nozzle orientation resulted in the best machining force, while at $0.5 \mathrm{wt} \%$ of $\mathrm{MoS}_{2}$ nanolubricant at 4 bar of pressure and $60^{\circ}$ nozzle orientation yields best surface quality. Zalaznik et al. [47] performed an investigation on the effect of type, size, and concentration of solid lubricants using $\mathrm{MoS}_{2}$ and tungsten 
Fig. 10 View of minimum quantity lubrication (MQL) and high-pressure coolant (HPC) coolant supply [35]

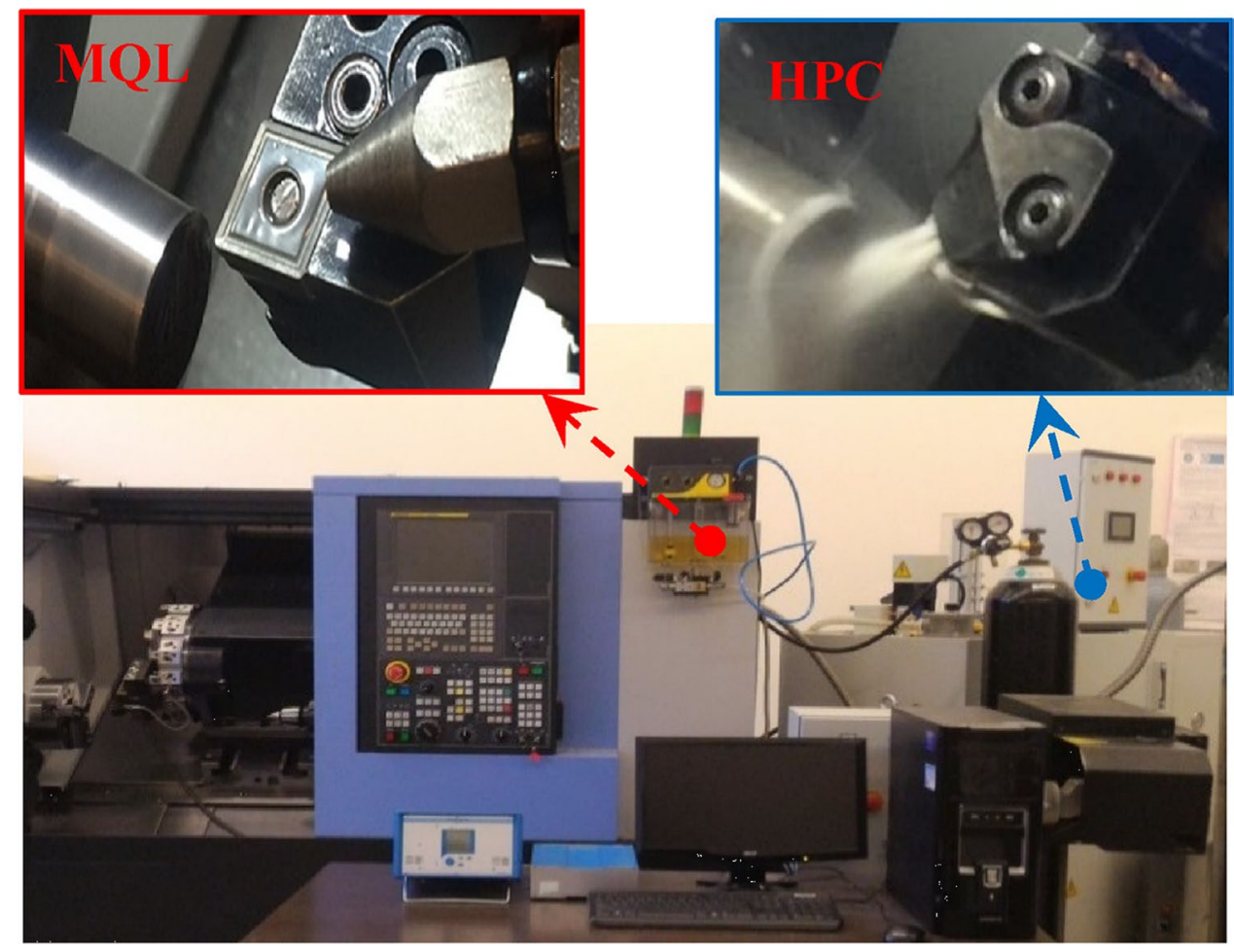

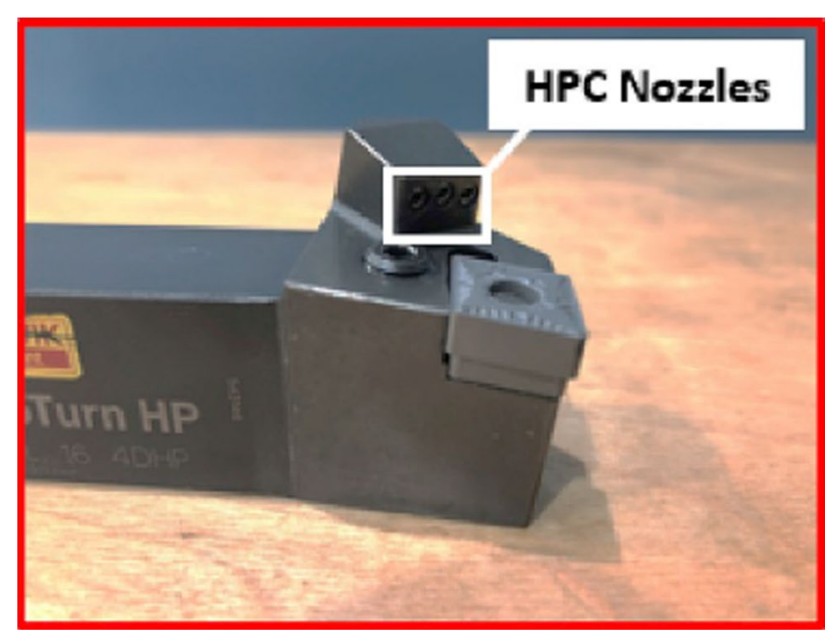

Fig. 11 View of coolant-through cutting tool holder [36]

disulfide $\left(\mathrm{WS}_{2}\right)$ on the tribological properties of polymer polyether ether ketone (PEEK). They showed that solid lubricant's microsize was able to reduce the generated friction by up to $30 \%$. However, they also mentioned that higher concentration of nanoscale particles is required to form a low friction tribo-film effectively to reduce the wear of the composites. A comparative performance study of different lubricants conducted by Sterle et al. [48] concluded that $\mathrm{MoS}_{2}$ outperformed other conventional lubricants. Sartori et al. [49] investigated solid lubricant-assisted MQL and minimum quantity cooling (MQC) strategies to improve the machinability of titanium alloy in turning operation as shown in Fig. 16. They concluded that solid lubricantassisted MQC was able to provide optimum lubrication and cooling capacities that resulted into reduction in tool wear in terms of flank and crater wears. Moreover, it reduced the overall surface roughness in comparison to dry and flooded machining.

\subsection{Machining under cryogenic cooling}

Cryogenic coolants as cutting fluids are also gaining interest from machining industries and researchers alike due to ecofriendliness while being recyclable and with no side effects on the machining operators. In cryogenic machining, liquid nitrogen $\left(\mathrm{LN}_{2}\right)$, carbon dioxide $\left(\mathrm{CO}_{2}\right)$, and compressed air were used for the delivery of the coolants onto tool-chip interface at low temperature of $-196{ }^{\circ} \mathrm{C}$ [50]. An example of cryogenic cooling delivery setup is shown in Fig. 17. The utilizations of liquid nitrogen effectively decreased the heat generation between the tool-workpiece interface rapidly while also providing lubrications at the cutting zone [51]. During the cryogenic cooling process, nitrogen evaporates at a rapid rate, therefore leaving no residue of cutting fluids to be disposed. Metal chips produced from the machining process under cryogenic cooling do not contain contaminations of metal-working fluids which allow easy recycling of the scrap metals [5]. Cryogenic cooling improved machinability by reduction of diffusion related tool wear mechanism at low operating temperature. Therefore, proper deployment 
Fig. 12 Visual representation of HPC cooling condition [38]

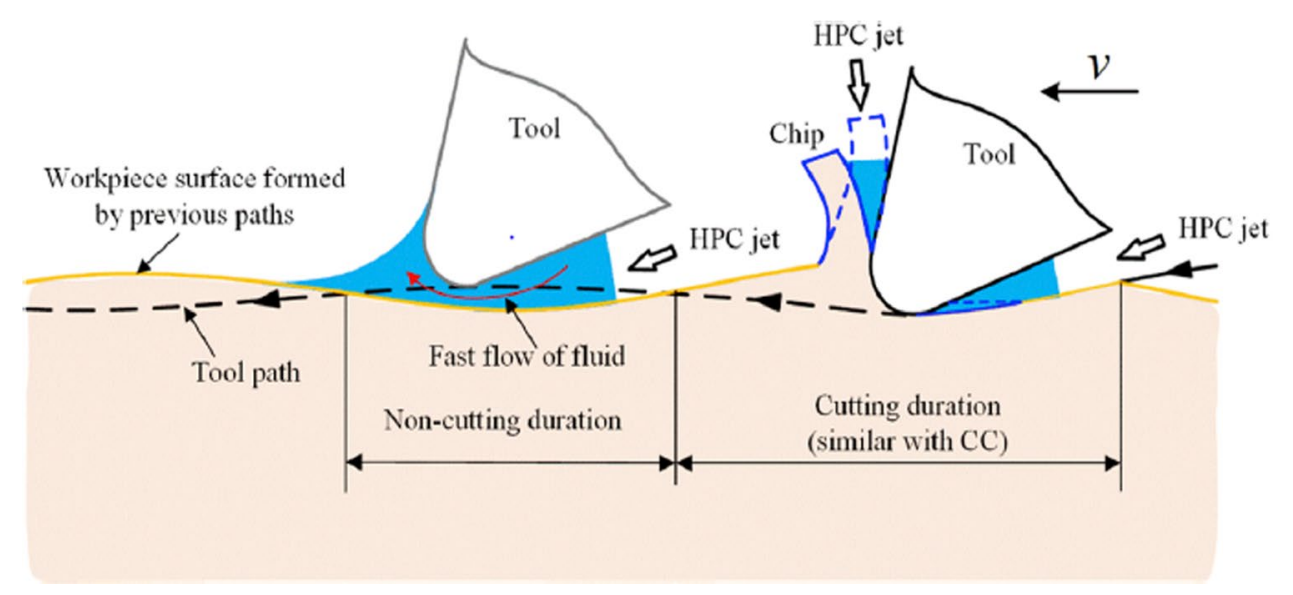

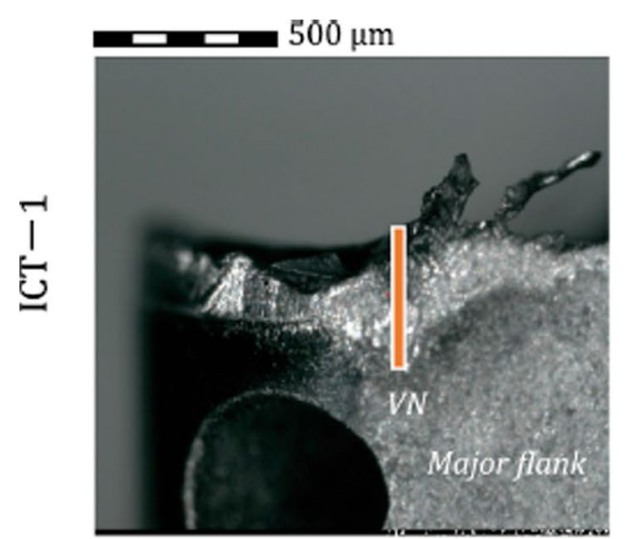
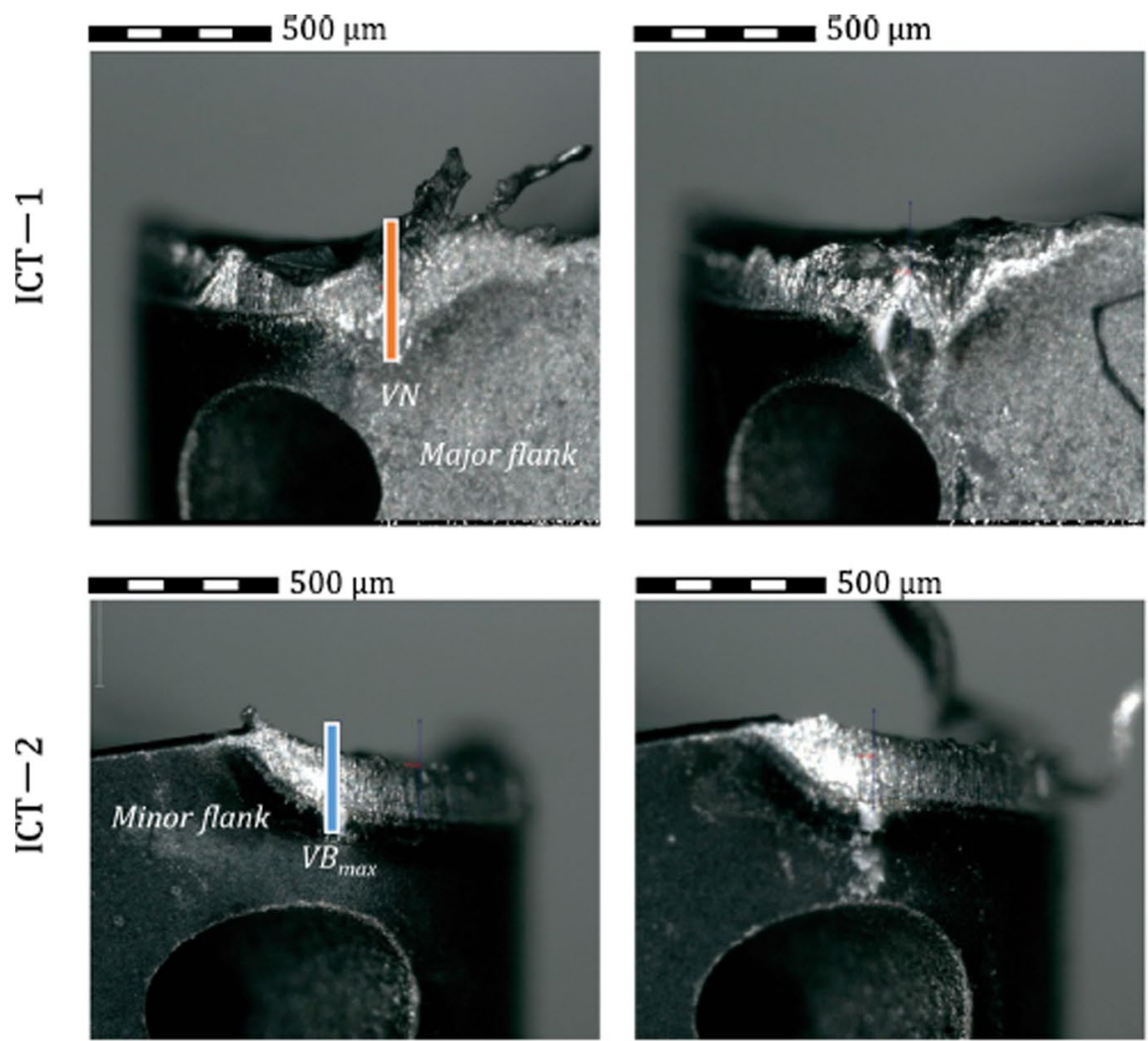

$P c=5 \mathrm{MPa}$

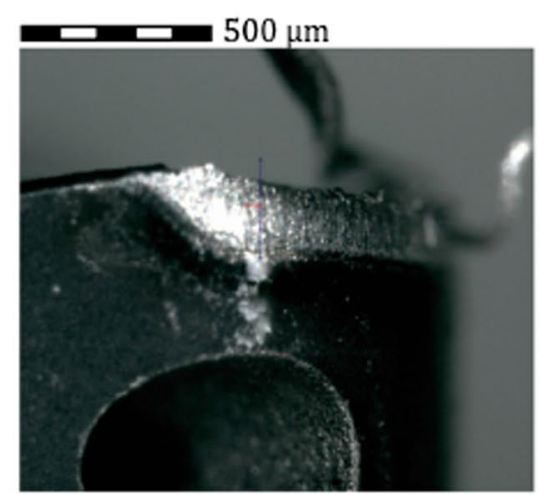

$P c=10 \mathrm{MPa}$
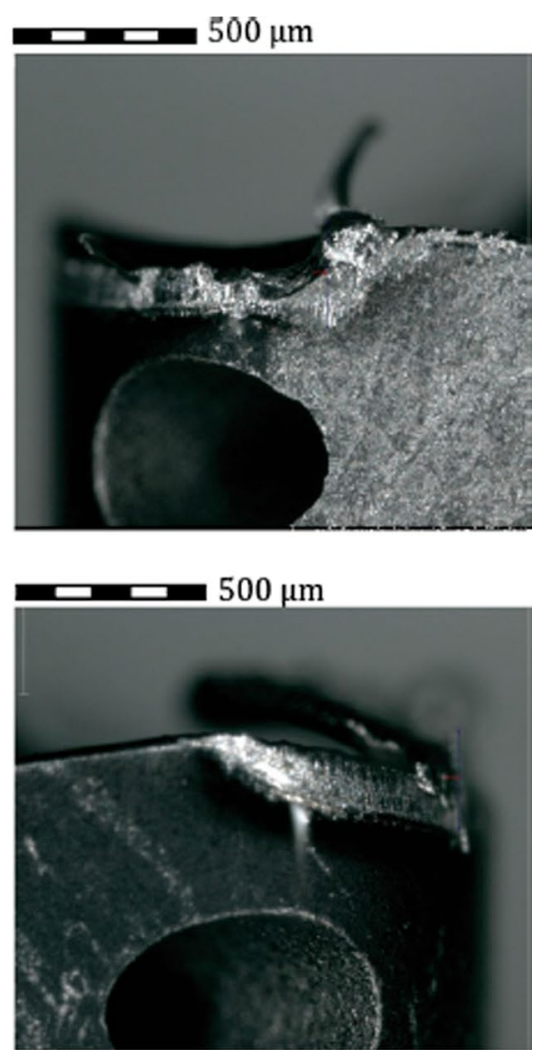

$P_{C}=15 \mathrm{MPa}$

Fig. 13 Tool wear performance of internal cooled tools at various coolant pressure [39]

of cryogenic cooling during any machining process is able to significantly improve machining quality and reduces manufacturing costs.

Many researchers investigated the effectiveness of cryogenic cooling in machining [53-59]. Sivaiah and Chakradhar [60] investigated the effect of cryogenic coolant on turning of 17-4 PH stainless steel and compared the performance of cryogenic coolant to that of MQL, flooded, and dry machining. They found that under cryogenic coolant-assisted machining, the overall machining performance was significantly improved in terms of surface roughness, tool wear, and chip thickness with better health and environmental benefits as shown in Fig. 18.

The characterization of machinability and environmental impact of cryogenic turning of titanium alloy conducted by Damir et al. [61] found that cryogenic coolant performed better than flooded coolant by decreasing $15 \%$ cutting forces, and better surface finish and tool life were also obtained. 
Fig. 14 a, b Surface roughness and tool life graph of high-pressure coolant-assisted machining [39]

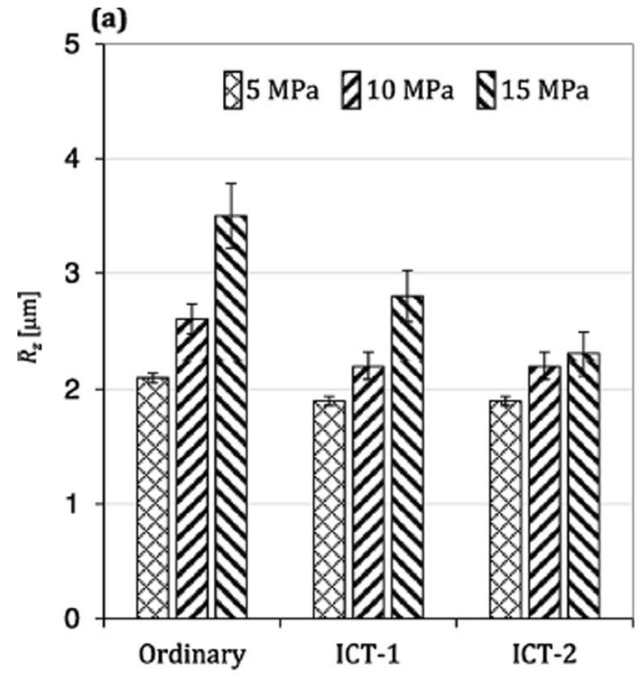

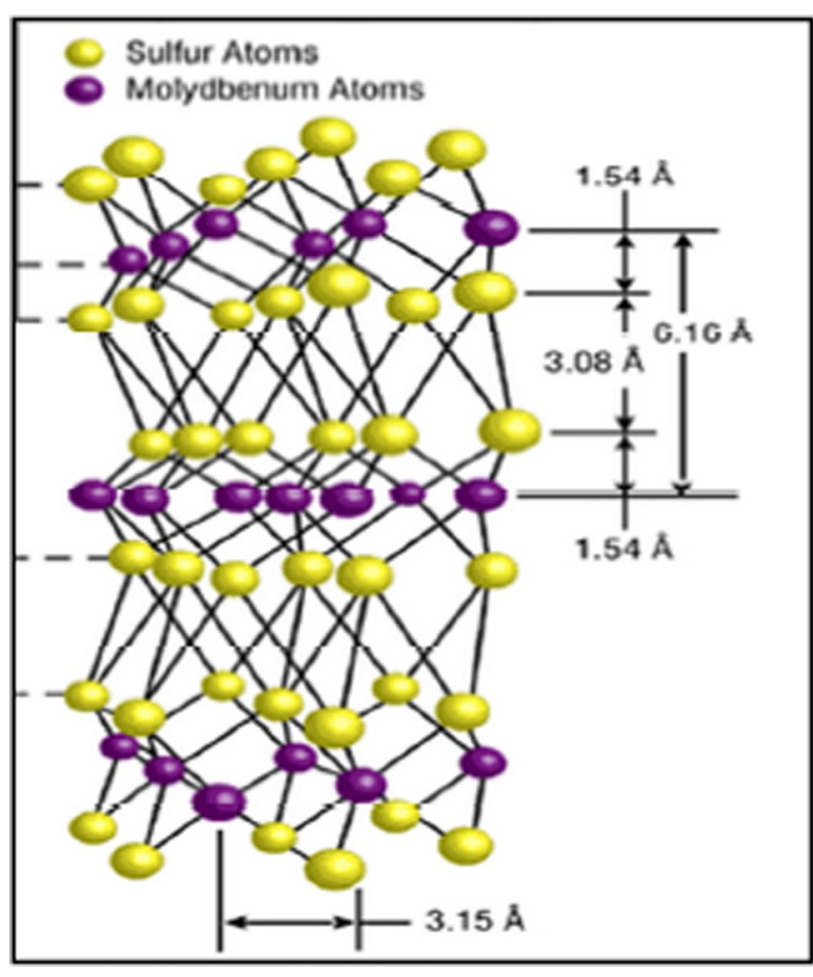

Fig. 15 Structure of molybdenum disulfide $\left(\mathrm{MoS}_{2}\right)[41]$

In recent study, Danish et al. [62] investigated the effect of cryogenic and dry machining on the surface integrity of AZ31C magnesium alloy. The authors concluded that cryogenic-assisted machining was able to produce improved surface finish in comparison to dry machining by margin close to 50\% as shown in Fig. 19. Moreover, microhardness of the magnesium alloy was increased drastically to 98.61 $\mathrm{HV}$ for cryogenic machining as compared to $76.10 \mathrm{HV}$ produced from dry machining observed in Fig. 20.

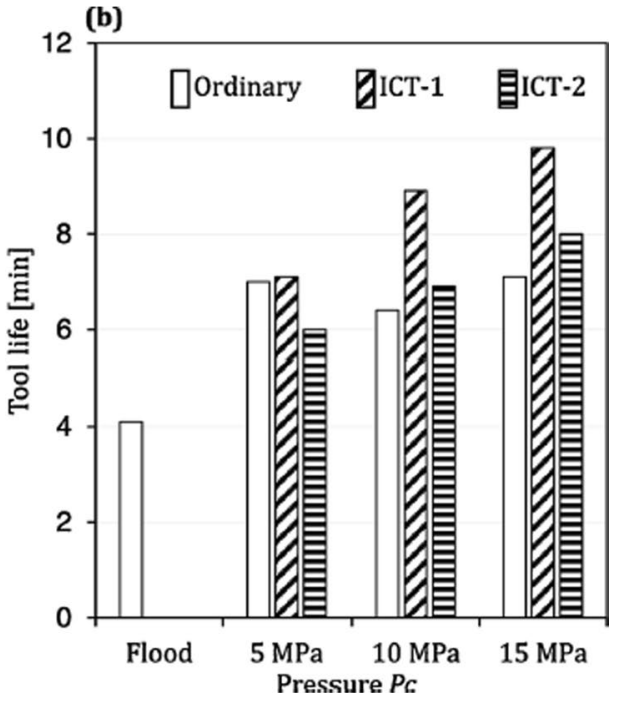

Kumar et al. [63] investigated the machinability and surface integrity of Ti/CFRP/Ti hybrid composite laminates under dry and cryogenic conditions. They found from the study that cryogenic condition not only reduced drilling torque by $7-25 \%$ but also surface integrity of drilled hole was improved from reduced built-up edge formations. Fernandes et al. [64] investigated the economics of turning operations on AISI D6 steel under dry, wet, and cryogenic conditions using $\mathrm{LN}_{2}$ at three different flow rates. They found that cryogenic turning of steel effectively enhanced tool life compared to dry and flooded machining under high liquid nitrogen flow rates. However, the machining costs were found to increase as the flow rate increased. Moreover, Stampfer et al. [65] concluded that machining forces and cutting tool temperatures were reduced by using high-pressure cryogenic coolant (nitrogen) supply on orthogonal turning of titanium alloy. Also, the tool wears on internal rake face of the cutting tool were reduced under cryogenic cooling compared to dry cutting. Wang et al. (2020) [66] performed research on hole milling on aramid fiber-reinforced composite (AFRP) under liquid nitrogen-based cryogenic cooling technique. They found that under cryogenic cooling, the cutting force and machining defects during the cutting process on AFRP were significantly improved in comparison to dry milling. Cutting temperature were significantly reduced under cryogenic cooling due to instantaneous heat removal at the cutting zone. The efficiency of chip removal under cryogenic cooling were also enhanced due to high outlet pressure, effectively suppressing erosion milling hole defect.

\section{Machining under the MQL technique}

Due to high volume of heat and stresses generated during machining process at tool-workpiece interface, cutting fluids are essential not only to remove heat but also to 
Fig. 16 Solid lubricant delivery setup in a MQL + PTFE and b MQC + graphite for titanium alloy machining [49]

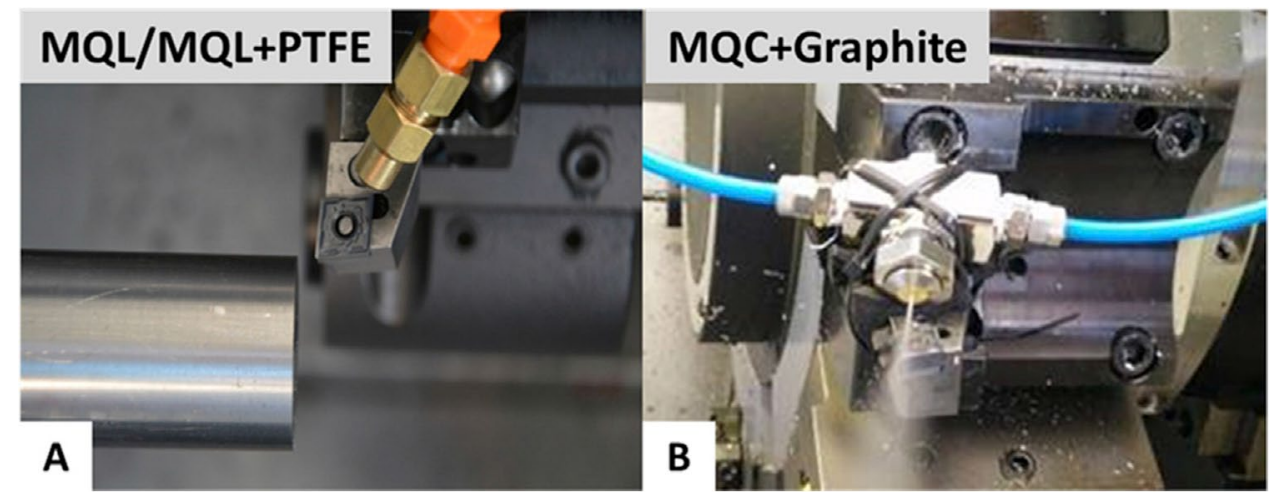

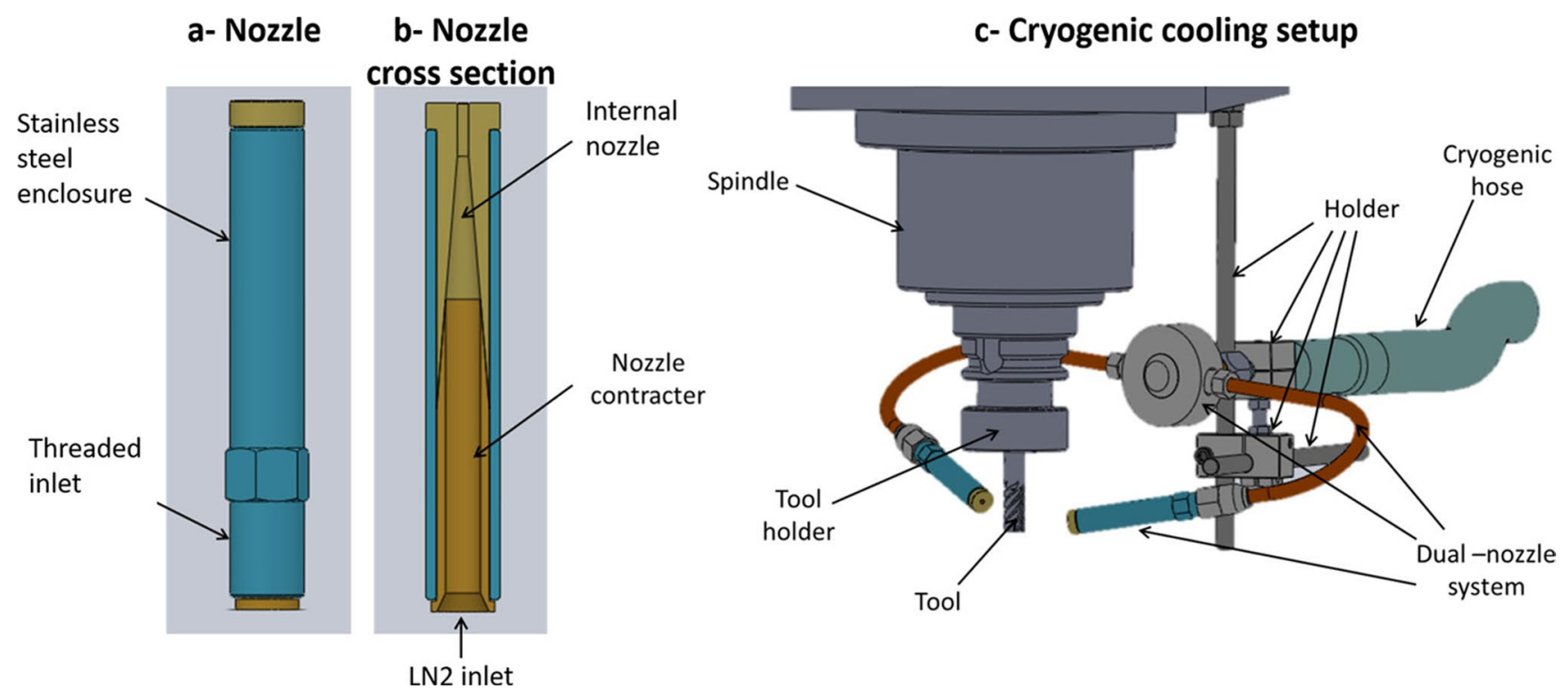

Fig. 17 Cryogenic nozzle layout and cryogenic machining cooling setup [52]

Fig. 18 Performance comparison of $\boldsymbol{a}$ tool rake wear and $\boldsymbol{b}$ surface roughness under dry, wet, MQL, and cryogenic machining [60]

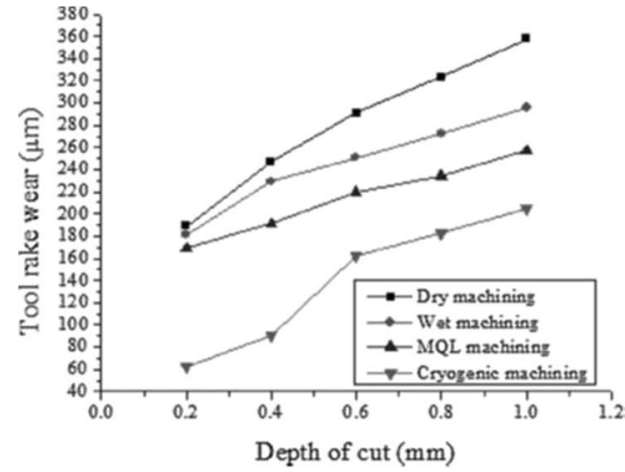

a)

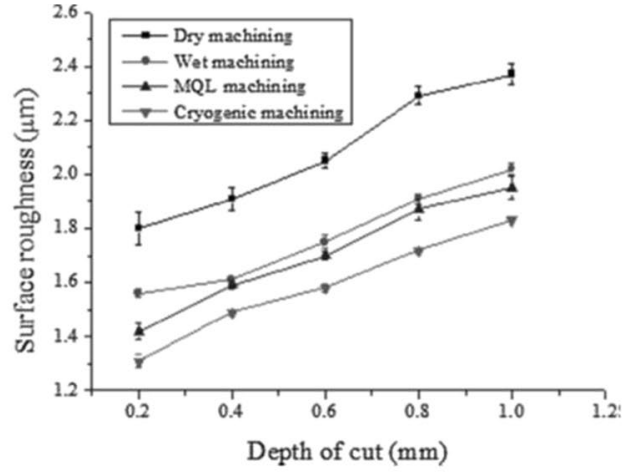

b) allow the surface to be lubricated, reducing temperature at tool surface, thus improving tool life and surface finish of the final product [67-73]. Dry machining was the first alternative method in manufacturing which eliminates cutting fluids during machining process. However, due to the lack of coolant or lubrication on the surface of machining tool and workpiece, more friction, heat, and adhesion were generated which results in high level of abrasion, diffusion, and lower surface finish and tool life [74, 75]. Thus, many researchers have been conducting studies on using 

performance on surface roughness [62]
Fig. 19 Cryogenic cooling

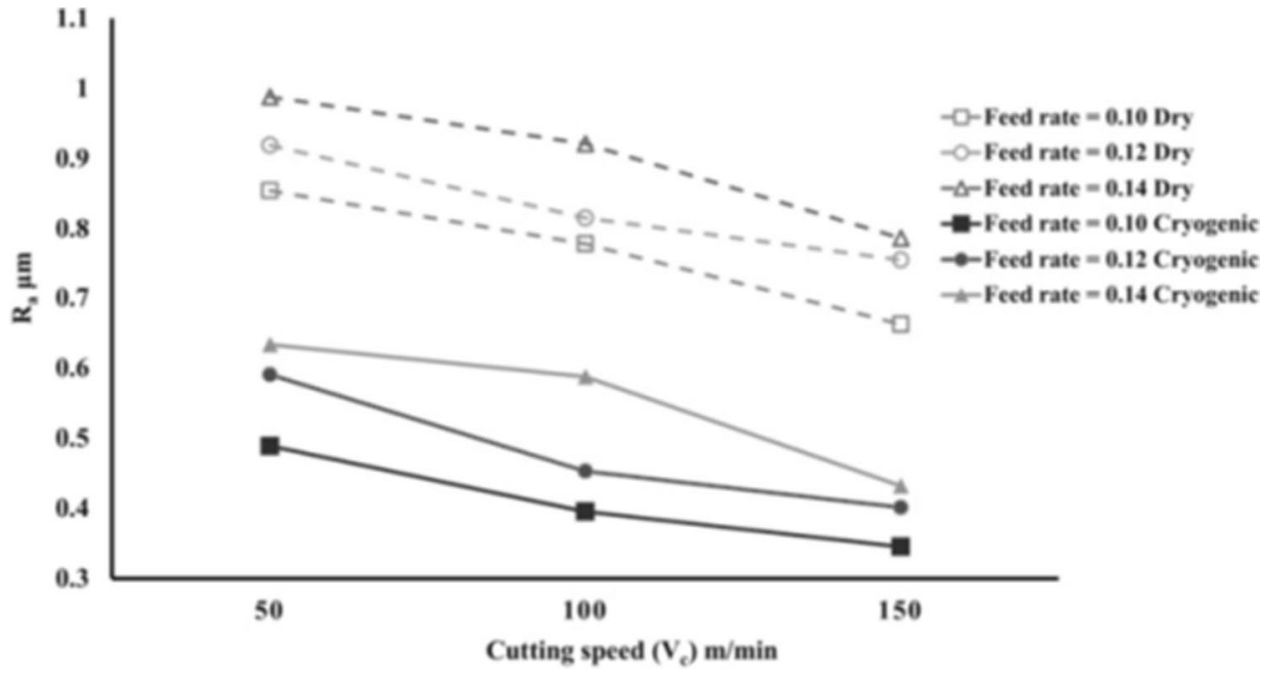

(a)

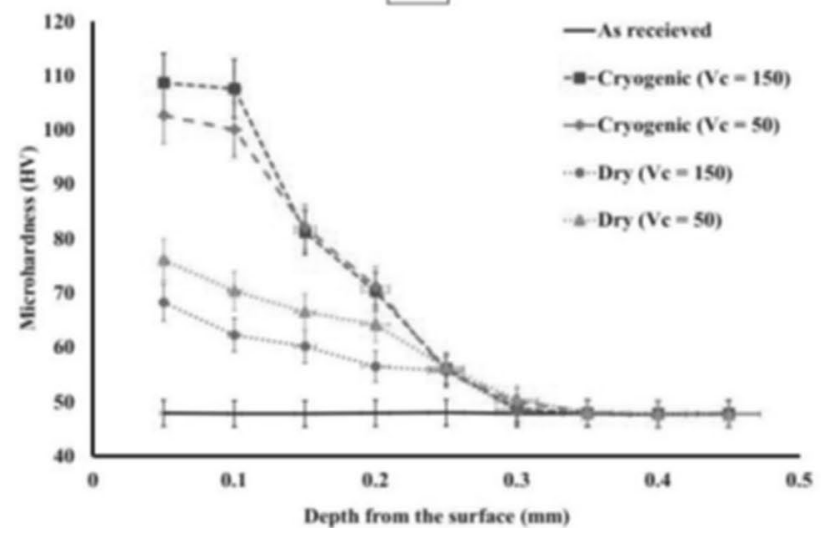

Fig. 20 a, b Effect of cryogenic and dry machining on microhardness improvement of magnesium alloy [62]

alternative methods of conventional cutting fluids applications such as flooded and minimum quantity lubrication techniques $[76,77,78,79,80]$. Conventional application of cutting fluids such as flooded machining and dry machining have been questioned for their sustainability in the machining industries which caused numerous environmental issues and health and safety concerns [81-86]. Hence, throughout the years, there are increasing number of studies of MQL fluid delivery method for optimum supply of cutting fluids during machining to effectively reduce manufacturing costs and improve the machinability [87-90]. The MQL cutting fluid delivery technique, which can also be referred as microlubrications or near-dry lubrications, involves significantly reduced lubricant/coolant which are hybrid coolant or water-based coolant delivered from the nozzle of a spray to the cutting zone via compressed air as delivering medium. Cutting fluids are usually sprayed at the cutting zone in mist form which function as both coolant and lubrication at the tool-workpiece interface [7-9].
The reduction of coolant allows for minimizing the total energy consumption and manufacturing costs [91-93].

Machining fluid accounts to about $20 \%$ of the total manufacturing cost; therefore, optimum use of cutting fluids became the top priority to maximize the profit in any manufacturing industries [8]. Two types of MQL were identified, namely internal and external mist supply as shown in Fig. 21. External application involves spraying lubricant directed at the tool-workpiece interface which requires manual adjustment of spray nozzle angle and positions. However, internal application requires specialized tool pieces that allows lubricant to be delivered through the cutting tool itself via internal through channels integrated in the tool [91].

Internal MQL application during drilling process can improve the chip removal efficiency for conventional mass production applications [94]. A comparative study between internal spray cooling and conventional external cooling in the drilling of Inconel 718 was conducted by Qin et al. [95]. They found that internal spray cooling 
(A)

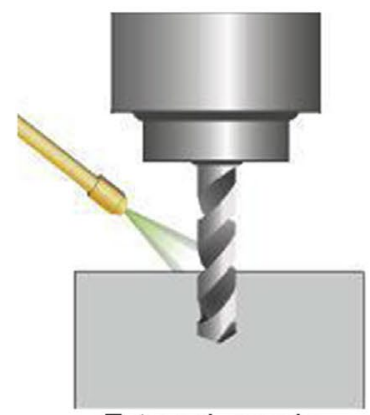

External supply
(B)

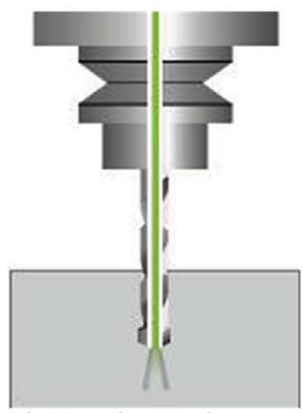

Internal supply

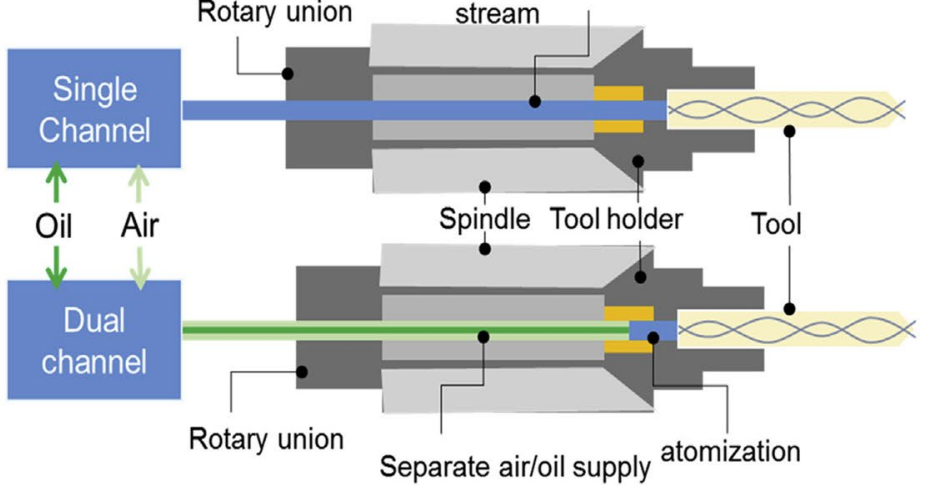

Fig. 21 a, b External and internal supply of MQL configurations for drilling [91]

is able to significantly reduce thrust force and improve tool life by two times over conventional external cooling. As a result, more stable surface roughness and accuracy of hole diameter were achieved. The MQL technique evolved and improved throughout the years of studies. These includes but not limited to usages of cutting fluids, search of optimum machining parameters suitable for the MQL method in various types of machining, and the suitability of MQL techniques in different types of metals and alloys which are presented in Figs. 22, 23, and 24.

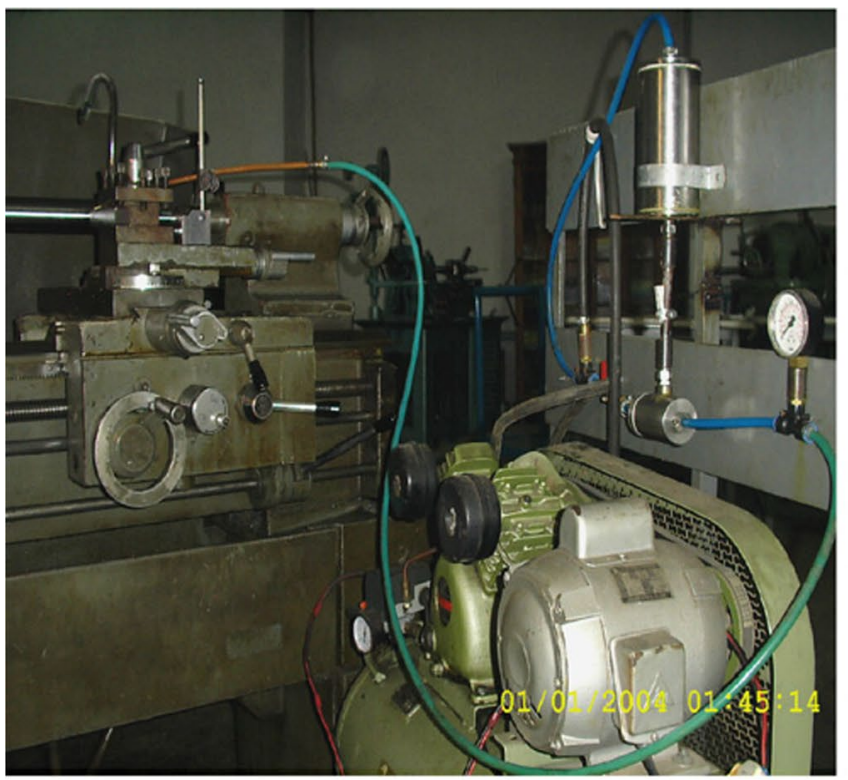

\subsection{MQL machining on steel}

Steel has been the most popular metal used in industries for decades. Thus, MQL techniques has been widely applied in machining of steel for manufacturing and research. A summary of the MQL machining of steel under different machining operation is presented in Table 1.

Many researchers (Choudhury and Dhar [106], Dhar et al. [96], Saha et al. [107], Uysal et al. [108], Garcia et al. [68], and Gupta et al. [109]) conducted experimental studies and concluded that the application of MQL in machining of steel were able to improve final surface roughness effectively. Dhar et al. [53] investigated the

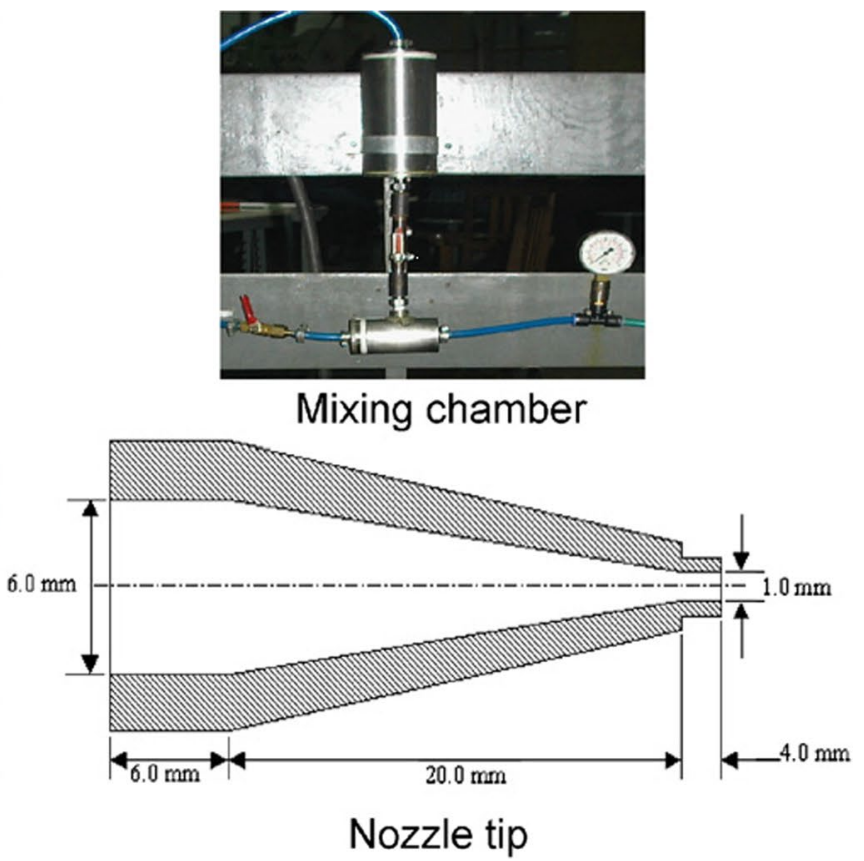

Fig. 22 View of the MQL experimental setup [96] 


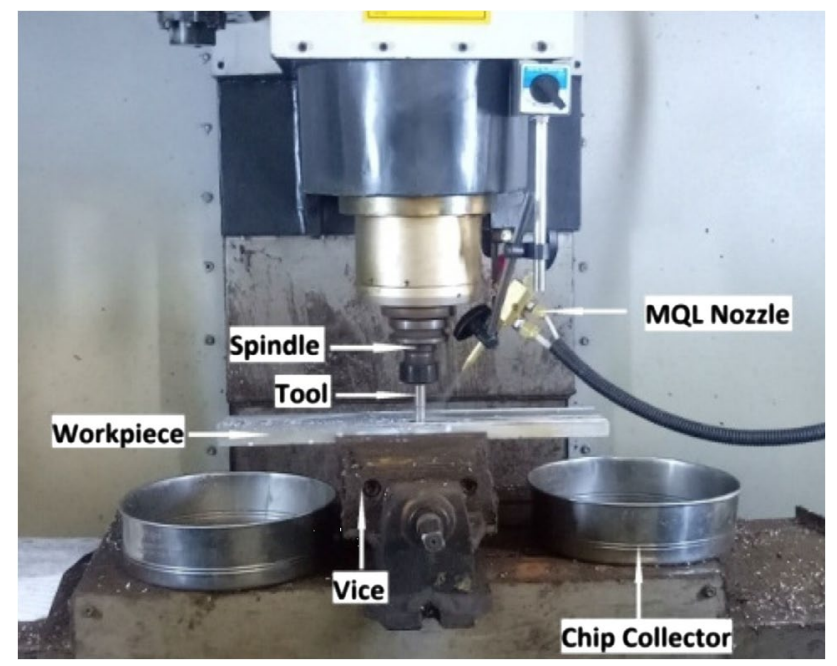

Fig. 23 External MQL delivery setup for milling [97]

influence of MQL on the cutting temperature, chip formation, and dimensional accuracy in turning of AISI-1040 steel. They concluded that the cutting performance of the MQL method surpassed the flooded cutting fluid delivery method. MQL was able to reduce cutting temperature and improve dimensional accuracy significantly due to the reduction of tool wear and improved lubrications at tool-workpiece interface. Kedare et al. [110] concluded that the MQL technique was preferred as an ideal replacement of dry machining to reduce negative aspects of cutting fluids and significantly improve overall cutting performances. Chinchanikar and Choudhury [99] demonstrated that lower cutting temperature improved tool life and better surface roughness were achieved under MQL techniques. Moreover, the study conducted by Vishnu et al. [12] on machining of EN 353 steel alloys using dry, flooded, and MQL conditions showed that there were minor differences in machining performances. They also mentioned that the MQL condition was the best choice of cutting fluid delivery. Tomaz et al. [103] studied the influence of MQL in the surface quality, machining forces, and residual stress of milled maraging 300 steels compared to flooded cooling under various cutting speeds, depth of cuts, and feed rates. MQL methods were found to reduce surface roughness by $10 \%$ in comparison to the flooded method while resultant force and residual stress generated by both methods were similar. Thus, the authors concluded that MQL applications were considered more economical and environmentally advantageous in the milling of maraging 300 alloy over flooded machining. Naresh Babu et al. [100] reported that AISI 304 steel end milling using MQL was able to reduce tool wear and surface roughness by $70 \%$ and $66 \%$ respectively compared to dry and flood lubrication as shown in Fig. 25.
Furthermore, Lai et al. [111] investigated the adaptability of AlTiN-based tool coating in machining of 316L stainless steel and concluded that near-dry cutting technologies like MQL techniques had great potentials to sustainable manufacturing for producing good surface finish and reducing the production cost. Özbek and Saruhan [70] studied the surface roughness and tool wear during eco-friendly MQL turning of AISI D2 steel under the effect of vibration and cutting zone temperature. The authors showed that the eco-friendly MQL system was superior to dry machining by improving $89 \%$ of surface roughness and $267 \%$ of tool wear. Mishra et al. [104] conducted a case study on the surface quality characteristic of MQL machining of high tensile steel. Experimental results showed that measured surface roughness values were under $1 \mu \mathrm{m}$ which were lower than the standard surface roughness criteria of $1.6 \mu \mathrm{m}$. Praveen et al. [105] experimentally found that MQL cutting fluid delivery was able to reduce surface roughness by $48.35 \%$ in comparison to dry machining during the machining of EN 47 chromium-vanadium steel materials at different level of cutting parameters as shown in Fig. 26.

Muaz and Choudhury [102] investigated solid lubricantassisted cutting fluids applied under MQL for AISI 4340 steel machining using TiCN/Al2O3/TiN chemical vapor deposition-coated tungsten carbide inserts during flat end milling process. They concluded that using recommended low viscosity cutting fluids under MQL led to environmentally and economically sound manufacturing. Bonfa et al. [101] studied the surface roughness of machined AISI D6 hardened steel and tool life of PCBN tools under MQL cooling. Vegetable-based MQL coolant were delivered at different location of cutting tools, namely the main and secondary tool flank faces and overhead of the cutting insert. When compared with dry turning, it was found that the MQL method provided better cooling and lubrications during machining, subsequently reducing surface roughness of AISI D6 steel and improving the tool life.

\subsection{Machining aluminum under MQL}

The MQL technique is not necessarily only applied on steel machining but also applied in other common metal machining such as aluminum. Table 2 shows the summary of the machining parameters for aluminum machining under the MQL method.

Sreejith [112] investigated machining of 6061 aluminum alloy under dry, flooded, and MQL conditions and concluded that MQL is the preferable choice for a coolant delivery method. Investigation of deep hole drilling on aluminum cast alloy using twist drill under MQL was performed by Biermann et al. [113]. The author concluded that MQL techniques was able to improve overall machining performance of aluminum alloy. Chatha et al. [114] concluded in 
Fig. 24 a-c The drilling process under MQL and flooded cooling [98]

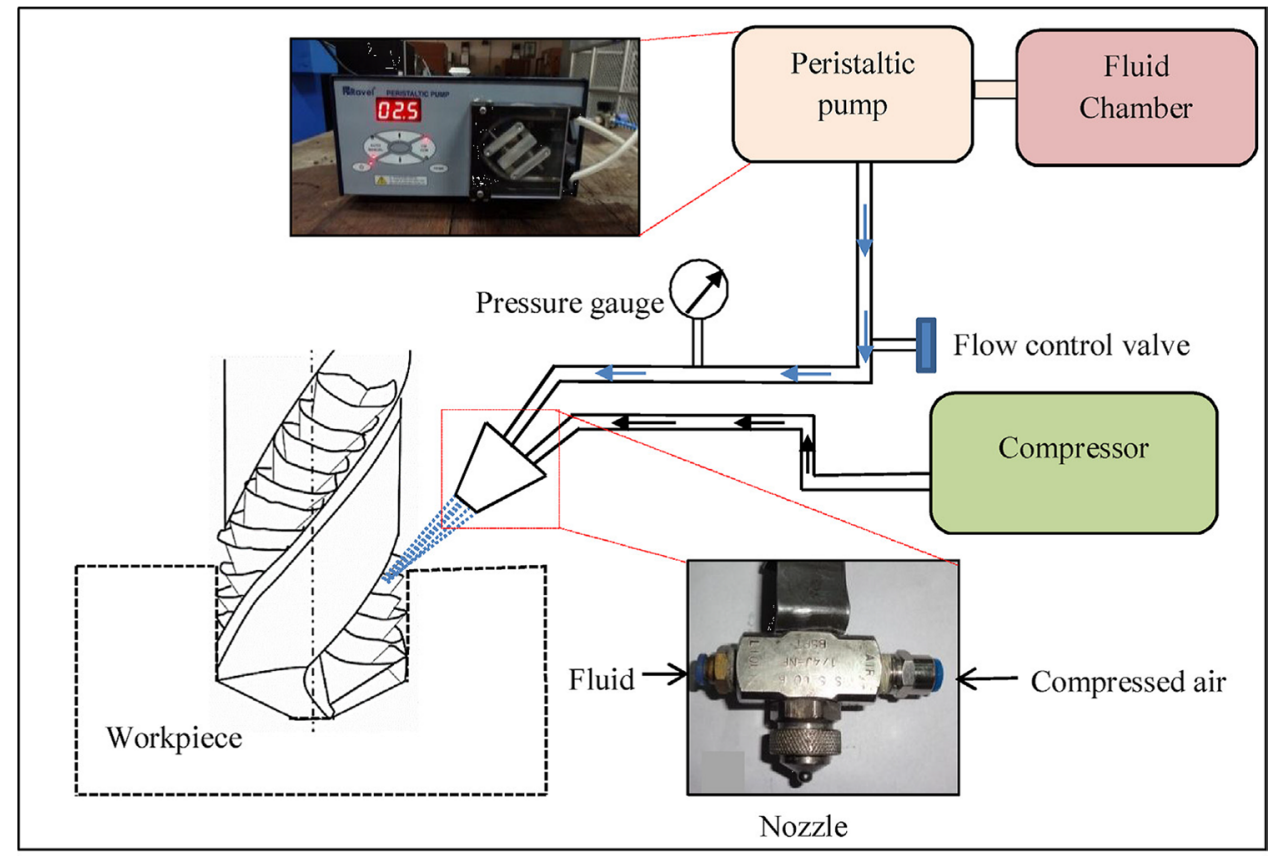

(a)

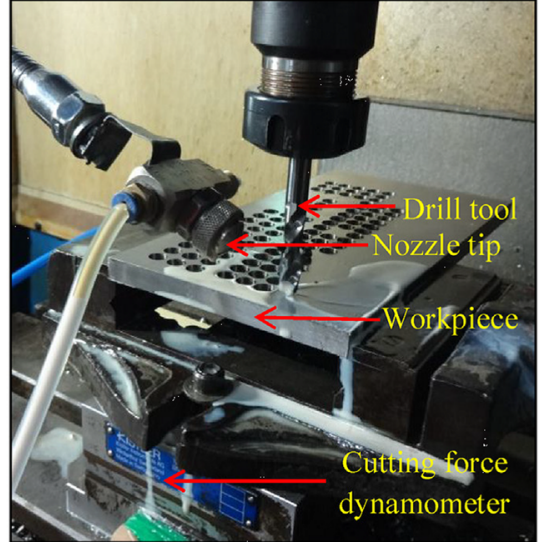

(b)

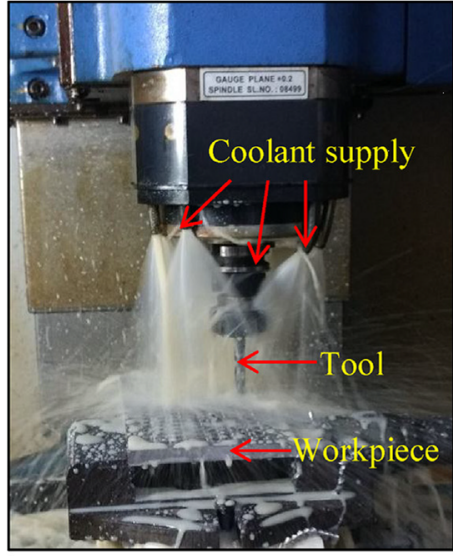

(c) their performance evaluation on aluminum drilling under the influence of MQL where the nanofluid MQL technique showed best results in terms of surface roughness, cutting forces, and tool wear compared to dry and flooded machining. Sumaiya Islam et al. [115] carried out experimental studies on the development of low-cost MQL setup for the turning operations of aluminum alloy 6061. Different variations of depth of cut and cutting speed along with cutting environments such as dry, flooded, and MQL conditions were used to evaluate the cutting performance of each parameter. The authors concluded that the performance of the MQL technique provided lower surface roughness and tool wear values at lower cutting temperature due to the improvement of lubrication penetration and chip flushing.
The MQL technique was also able to reduce the formation of built-up edges (BUE) and decreased chip thickness as compared to wet and dry machining. Shukla et al. [97] conducted experiments to study the characterization of vegetable oil as lubricant on CNC milling of aluminum 6061 under dry, flood, and MQL cutting fluid delivery methods. In the research, they found that surface roughness and tool wear were significantly improved under MQL-assisted cooling techniques on aluminum milling at lower cutting speeds. Another study completed by Zhu et al. [117] investigated the temperature distribution on the tools during MQL-assisted aluminum drilling using different cutting parameters. The study showed that the MQL coolant delivery system was able to better reduce cutting temperature when compared to 
Table 1 Process parameters used during steel MQL machining using various machining operations

\begin{tabular}{|c|c|c|c|c|c|c|c|}
\hline Ref & Material & $\begin{array}{l}\text { Machining } \\
\text { process }\end{array}$ & Lubrication & $\begin{array}{l}\text { Cutting speed } \\
(\mathrm{m} / \mathrm{min})\end{array}$ & Feed $(\mathrm{mm} / \mathrm{min})$ & $\begin{array}{l}\text { Depth of cut } \\
(\mathrm{mm})\end{array}$ & Responses \\
\hline [53] (2006) & C60 steel & Turning & MQL & 110 & 0.20 & 2.0 & $\begin{array}{l}\text { Surface roughness, } \\
\text { tool wear }\end{array}$ \\
\hline [99] (2014) & AISI 4340 steel & Turning & MQL & $100,125,150$ & 0.088 & 0.3 & Tool wear, tool life \\
\hline [98 (2014) & $\begin{array}{l}15 \text { HRC mild } \\
\text { steel }\end{array}$ & Milling & MQL & $160,225,300$ & - & $0.1,0.2,0.3$ & $\begin{array}{l}\text { Surface rough- } \\
\text { ness, machining } \\
\text { temperature }\end{array}$ \\
\hline [12] (2018) & EN 353 steel & Turning & MQL & $\begin{array}{l}73.3,115.19 \\
157.08\end{array}$ & $0.2,0.5,0.8$ & $0.5,1.5,2.5$ & $\begin{array}{l}\text { Cutting tempera- } \\
\text { ture }\end{array}$ \\
\hline [100] (2019) & AISI 304 steel & Turning & MQL & 100,150 & $300,400,500$ & $\mathrm{n} / \mathrm{a}$ & $\begin{array}{l}\text { Surface roughness, } \\
\text { tool wear, chip } \\
\text { morphology }\end{array}$ \\
\hline [101] (2019) & AISI D6 steel & Turning & MQL & $\begin{array}{c}160,190,250, \\
310,340\end{array}$ & $\begin{array}{c}0.05,0.10,0.15, \\
0.20,0.25\end{array}$ & 0.05 & $\begin{array}{l}\text { Tool life, tool wear } \\
\text { mechanisms, sur- } \\
\text { face roughness }\end{array}$ \\
\hline [102] (2019) & AISI 4340 steel & Milling & MQL & $251.37,376.99$ & $0.05,0.066$ & 0.5 & $\begin{array}{l}\text { Surface roughness, } \\
\text { resultant force }\end{array}$ \\
\hline [103] (2019) & 300 steel & Milling & MQL & 100,200 & $0.02,0.1$ & $1.0,2.0$ & $\begin{array}{l}\text { Machining force, } \\
\text { surface rough- } \\
\text { ness }\end{array}$ \\
\hline [104] (2020) & EN24 steel & Turning & MQL & $80,160,240$ & $0.04,0.08,0.12$ & $0.2,0.3,0.4$ & Surface roughness \\
\hline [105] (2021) & EN47 steel & Turning & MQL & $256,399,625$ & $0.10,0.15,0.20$ & $0.1,0.15,0.2$ & Surface roughness \\
\hline
\end{tabular}

\begin{tabular}{|c|c|c|c|c|c|c|c|}
\hline Trial & Cutting speed $(\mathrm{m} / \mathrm{min})$ & Environment & Feed $(\mathrm{mm} / \mathrm{min})$ & $\operatorname{Ra}(\mu \mathrm{m})$ & Tool wear $(\mathrm{mm})$ & Grade & Rank \\
\hline 1 & 100 & Dry & 300 & 2.54 & 0.32 & 0.3469 & 14 \\
\hline 2 & 100 & Dry & 400 & 2.08 & 0.6 & 0.1754 & 18 \\
\hline 3 & 100 & Dry & 500 & 1.88 & 0.58 & 0.2353 & 17 \\
\hline 4 & 100 & MQL & 300 & 1.68 & 0.23 & 0.5762 & 5 \\
\hline 5 & 100 & $\mathrm{MQL}$ & 400 & 1.68 & 0.21 & 0.5912 & 3 \\
\hline 6 & 100 & MQL & 500 & 1.79 & 0.26 & 0.5276 & 10 \\
\hline 7 & 100 & Flood & 300 & 0.58 & 0.46 & 0.5807 & 4 \\
\hline 8 & 100 & Flood & 400 & 1.59 & 0.35 & 0.4889 & 11 \\
\hline 9 & 100 & Flood & 500 & 2.11 & 0.29 & 0.4377 & 12 \\
\hline 10 & 150 & Dry & 300 & 1.98 & 0.34 & 0.4141 & 13 \\
\hline 11 & 150 & Dry & 400 & 2.67 & 0.39 & 0.2635 & 16 \\
\hline 12 & 150 & Dry & 500 & 1.58 & 0.56 & 0.3204 & 15 \\
\hline 13 & 150 & MQL & 300 & 0.37 & 0.44 & 0.6207 & 2 \\
\hline 14 & 150 & $\mathrm{MQL}$ & 400 & 0.48 & 0.5 & 0.5619 & 6 \\
\hline 15 & 150 & MQL & 500 & 1.37 & 0.33 & 0.5585 & 8 \\
\hline 16 & 150 & Flood & 300 & 0.6 & 0.4 & 0.6318 & 1 \\
\hline 17 & 150 & Flood & 400 & 1.85 & 0.24 & 0.5314 & 9 \\
\hline 18 & 150 & Flood & 500 & 2.13 & 0.11 & 0.5612 & 7 \\
\hline
\end{tabular}

Fig. 25 Taguchi experimental design for L18 array [100]

dry and air-cooling conditions. Kannan et al. [116] reported that the MQL techniques improved cutting forces, surface roughness, and tool wears in comparison to dry and flooded machining in turning of unreinforced aluminum alloy as shown in Figs. 27, 28, and 29.

Abas et al. [118] studied the optimization of machining parameters such as depth of cut, feed rate, cutting speed, and positive rake angle which affect surface roughness, tool life, and material removal rate of aluminum alloy under MQL-assisted turning process. They found that MQL was more efficient in comparison to dry machining in terms of better surface finish and longer tool life. Cagan et al. [119] investigated the surface roughness and chip morphology of aluminum alloy in dry and MQL machining. They found from their experimental results that the surface quality was improved by $15 \%$ under MQL conditions in comparison to dry machining as shown in Fig. 30, and MQL techniques were more environmentally friendly and provided better machining quality than dry machining.

In a more recent study, Javidikia et al. [120] reported the effect of turning environments and machining parameters on the surface finish of aluminum alloy at low-speed and 
Fig. 26 Improved surface roughness comparison of dry machining and MQL [105]

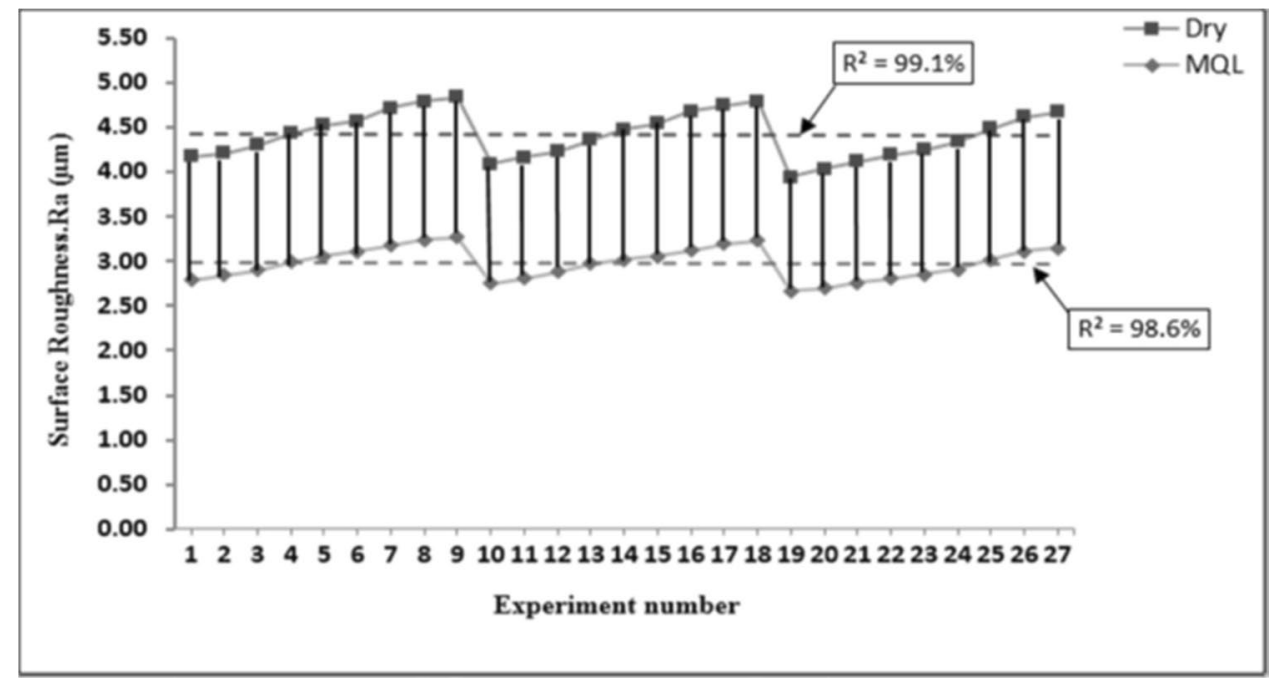

Table 2 Process parameters used during MQL machining of aluminum

\begin{tabular}{|c|c|c|c|c|c|c|c|}
\hline Ref & Material & $\begin{array}{l}\text { Machining } \\
\text { process }\end{array}$ & Lubrication & $\begin{array}{l}\text { Cutting speed } \\
(\mathrm{m} / \mathrm{min})\end{array}$ & $\begin{array}{l}\text { Feed rate }(\mathrm{mm} / \\
\text { min) }\end{array}$ & $\begin{array}{l}\text { Depth of cut } \\
(\mathrm{mm})\end{array}$ & Responses \\
\hline [112] (2008) & 6061 aluminum & Turning & MQL & 400 & 0.15 & 1.0 & $\begin{array}{l}\text { Surface roughness, } \\
\text { tool wear, cutting } \\
\text { force }\end{array}$ \\
\hline [113] (2012) & $\begin{array}{l}\text { EN AC46000 } \\
\text { aluminum }\end{array}$ & Drilling & MQL & $140,170,200$ & $0.1,0.2,0.3$ & 250 & $\begin{array}{l}\text { Machining tem- } \\
\text { perature }\end{array}$ \\
\hline [114] (2016) & 6063 aluminum & Drilling & MQL & $30,53.7$ & 60 & 20 & $\begin{array}{l}\text { Drilling thrust } \\
\text { force, drilling } \\
\text { torque, surface } \\
\text { roughness, tool } \\
\text { wear }\end{array}$ \\
\hline [115] (2017) & 6061 aluminum & Turning & MQL & $300,420,700$ & 0.15 & $1.0,1.5$ & $\begin{array}{l}\text { Surface roughness, } \\
\text { tool wear }\end{array}$ \\
\hline [97] (2020) & 6061 aluminum & Drilling & MQL & $100,200,300$ & $\begin{array}{l}0.045,0.0675 \\
0.09\end{array}$ & $0.5,1.0,1.5$ & $\begin{array}{l}\text { Surface roughness, } \\
\text { tool wear }\end{array}$ \\
\hline [116] (2020) & 7075 aluminum & Turning & MQL & 150,250 & $0.1,0.2,0.3$ & $\mathrm{n} / \mathrm{a}$ & $\begin{array}{l}\text { Cutting force, sur- } \\
\text { face roughness, } \\
\text { tool wear }\end{array}$ \\
\hline [117] (2020) & $\begin{array}{l}\text { AA2024 alu- } \\
\text { minum }\end{array}$ & Drilling & MQL & $60,80,100,120$ & $0.2,0.3,0.4,0.5$ & $\mathrm{n} / \mathrm{a}$ & $\begin{array}{l}\text { Drilling thrust } \\
\text { force, drilling } \\
\text { torque, machin- } \\
\text { ing temperature, } \\
\text { tool wear }\end{array}$ \\
\hline [118] (2020) & 6026 aluminum & Turning & MQL & $\begin{array}{l}400,500,600, \\
\quad 700\end{array}$ & $0.3,0.4,0.5,0.6$ & $1.0,1.5,2.0,2.5$ & $\begin{array}{l}\text { Surface roughness, } \\
\text { tool life, material } \\
\text { removal rate }\end{array}$ \\
\hline [119] (2020) & $\begin{array}{r}\text { AL7075-T6 } \\
\text { aluminum }\end{array}$ & Turning & MQL & $400,450,500$ & 0.1 & 1 & $\begin{array}{l}\text { Surface roughness, } \\
\text { chip morphology }\end{array}$ \\
\hline [120] (2020) & $\begin{array}{l}\text { 6061-T6 alu- } \\
\text { minum }\end{array}$ & Turning & MQL & $\begin{array}{l}145,350,650, \\
950,1155\end{array}$ & $\begin{array}{c}0.07,0.12,0.19, \\
0.26,0.31\end{array}$ & $\begin{array}{c}0.66,1.0,1.5, \\
2.0,2.34\end{array}$ & $\begin{array}{l}\text { Surface roughness, } \\
\text { residual stress, }\end{array}$ \\
\hline
\end{tabular}

high-speed turning. The machining was carried out under dry, wet, and minimum quantity lubrication environments combined with various cutting speed, feed rate, and depth of cut. They found that changing of cutting speeds and feed rates had significant effects in MQL turning environments especially at high cutting speed. The MQL cooling 
Fig. 27 Cutting force comparison between dry and MQLassisted aluminum alloy turning at cutting speed of $150 \mathrm{~m} / \mathrm{min}$ (a) and $250 \mathrm{~m} / \mathrm{min}(\boldsymbol{b})$ [116]
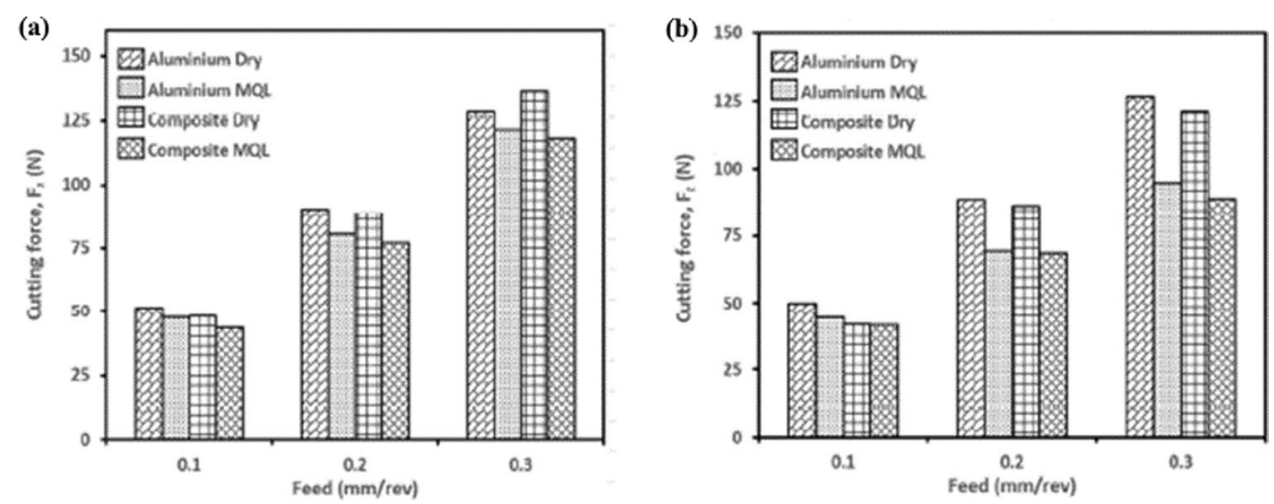
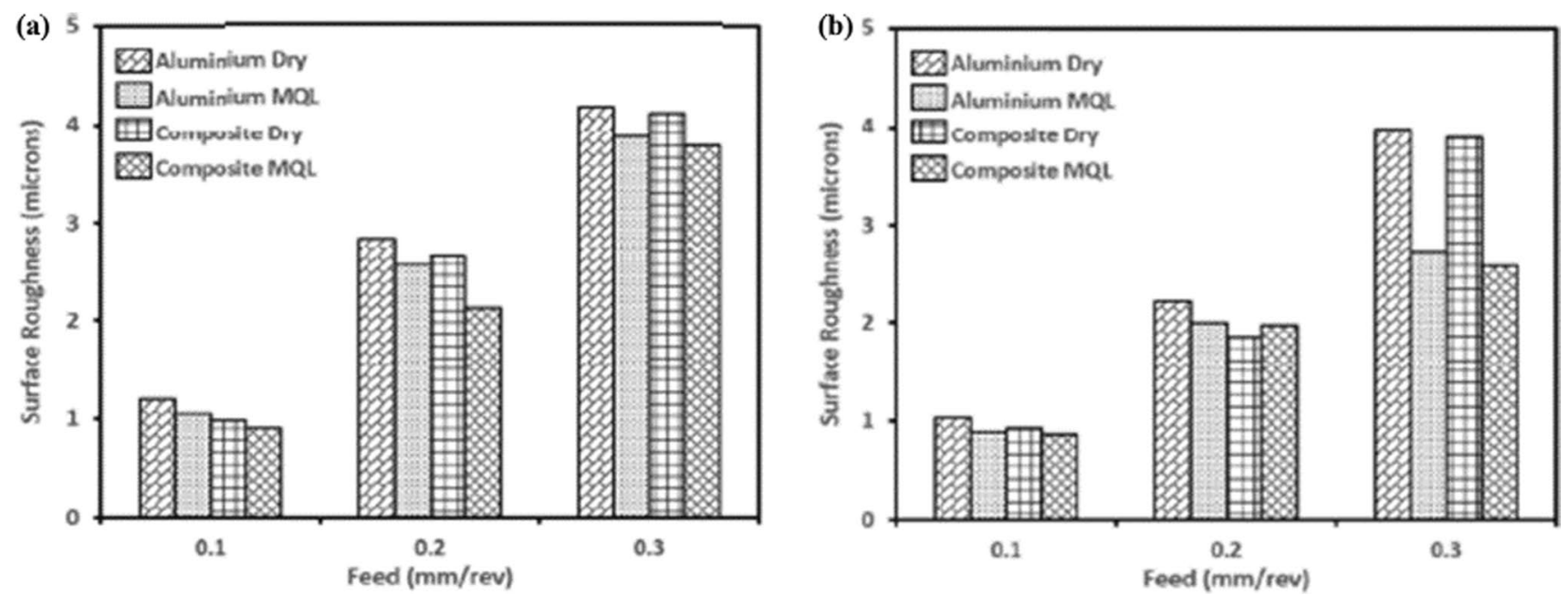

Fig. 28 Surface roughness comparison between dry and MQL-assisted aluminum alloy turning at cutting speed of $150 \mathrm{~m} / \mathrm{min}(\boldsymbol{a})$ and $250 \mathrm{~m} / \mathrm{min}$ (b) [116]

Fig. 29 Tool flank wear comparison between dry and MQLassisted aluminum alloy turning at cutting speed of $150 \mathrm{~m} / \mathrm{min}$ (a) and $250 \mathrm{~m} / \mathrm{min}(\boldsymbol{b})$ [116]
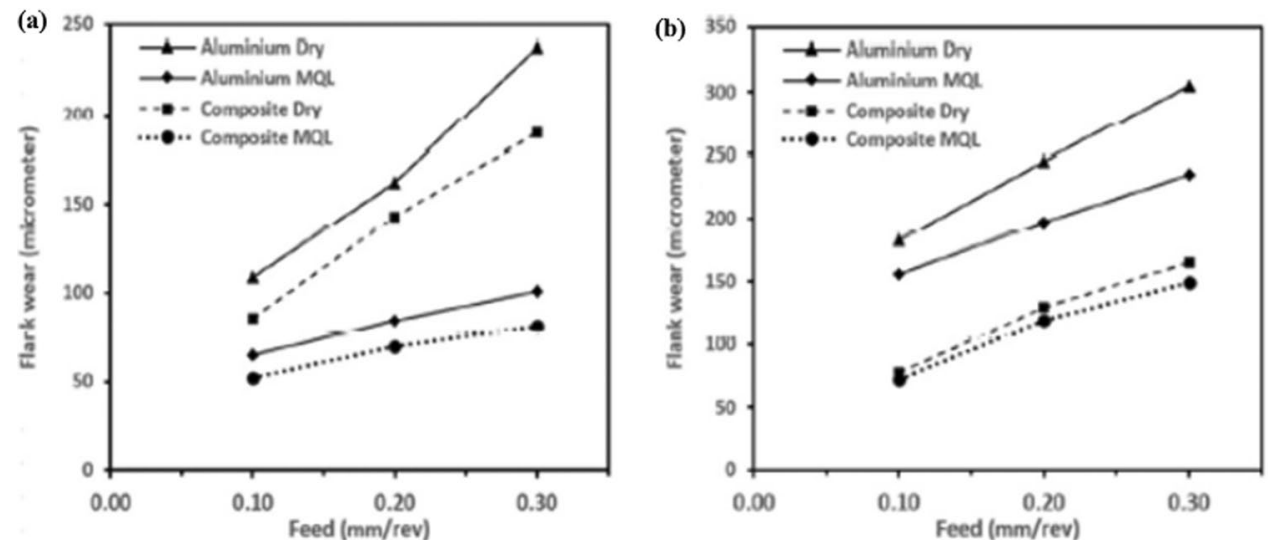

method also produced lower surface roughness value on the aluminum workpieces; thus, it is recommended as the most eco-friendly cooling methods in machining.

\subsection{MQL machining on alloys and hybrid composites}

The MQL technique is also applicable in the case of metal alloys which has prompted several researches summarized in Table 3 over the years by various authors [123, 130-134]. 


\begin{tabular}{|c|c|c|c|c|c|c|}
\hline \multirow[t]{2}{*}{ Experiments } & \multicolumn{4}{|l|}{ Parameters } & \multicolumn{2}{|l|}{ Results } \\
\hline & Conditions & Cutting speed (m/min) & Feed rate $(\mathrm{mm} / \mathrm{rev})$ & Depth of cut (mm) & $\operatorname{Ra}(\mu \mathrm{m})$ & Standard Deviation \\
\hline 1 & Dry & 400 & 0.1 & 1 & 0.75533 & 0.05839 \\
\hline 2 & Dry & 450 & 0.1 & 1 & 0.73833 & 0.03355 \\
\hline 3 & Dry & 500 & 0.1 & 1 & 0.73467 & 0.03972 \\
\hline 4 & MQL & 400 & 0.1 & 1 & 0.64833 & 0.01002 \\
\hline 5 & MQL & 450 & 0.1 & 1 & 0.65467 & 0.01419 \\
\hline 6 & MQL & 500 & 0.1 & 1 & 0.65533 & 0.01528 \\
\hline
\end{tabular}

Fig. 30 Surface roughness performance of dry and MQL-assisted aluminum alloy machining [119]

Table 3 Process parameters used during MQL machining of alloys using various operations

\begin{tabular}{|c|c|c|c|c|c|c|c|}
\hline Ref & Material & $\begin{array}{l}\text { Machining } \\
\text { process }\end{array}$ & Lubrication & $\begin{array}{l}\text { Cutting speed } \\
(\mathrm{m} / \mathrm{min})\end{array}$ & $\begin{array}{l}\text { Feed rate }(\mathrm{mm} / \\
\mathrm{min})\end{array}$ & $\begin{array}{l}\text { Depth of cut } \\
(\mathrm{mm})\end{array}$ & Responses \\
\hline [121] (2002) & A356 alloy & Drilling & MQL & 300 & $0.1,0.2$ & - & $\begin{array}{l}\text { Tool wear, cutting } \\
\text { forces, power } \\
\text { consumption, } \\
\text { surface rough- } \\
\text { ness }\end{array}$ \\
\hline [122] (2009) & AISI 9310 alloy & Turning & MQL & $\begin{array}{l}223,246,348, \\
483\end{array}$ & $\begin{array}{l}0.10,0.13,0.16 \\
\quad 0.18\end{array}$ & 1.0 & $\begin{array}{l}\text { Chip formation, } \\
\text { tool wear, surface } \\
\text { roughness }\end{array}$ \\
\hline [123] (2018) & Incoloy 800 & Turning & MQL & $40,50,60$ & $\begin{array}{l}0.033,0.066 \\
0.132\end{array}$ & $0.50,0.75,1.0$ & $\begin{array}{l}\text { Surface roughness, } \\
\text { tool wear }\end{array}$ \\
\hline [124] (2018) & Inconel 718 alloy & Turning & MQL & $40,50,60$ & $0.08,0.125,0.16$ & 0.3 & $\begin{array}{l}\text { Cutting force, tool } \\
\text { wear, surface } \\
\text { roughness }\end{array}$ \\
\hline [125] (2020) & Inconel 718 alloy & Milling & MQL & 25.1 & 0.05 & 0.4 & Surface roughness \\
\hline [126] (2020) & CFRP & Drilling & MQL & 90 & $0.2-8$ & $\begin{array}{l}1.0,4.0,7.0, \\
12.0\end{array}$ & $\begin{array}{l}\text { Drilling thrust } \\
\text { force, drilling } \\
\text { torque, delami- } \\
\text { nation, hole } \\
\text { diameter1 }\end{array}$ \\
\hline [127] (2020) & Inconel 625 alloy & Turning & MQL & $50,75,100$ & 0.12 & 0.5 & $\begin{array}{l}\text { Tool wear, machin- } \\
\text { ing temperature, } \\
\text { surface rough- } \\
\text { ness, chip mor- } \\
\text { phology }\end{array}$ \\
\hline [128] (2020) & TC4 alloy & Milling & MQL & $\begin{array}{l}600,1200,1800, \\
2400\end{array}$ & $\mathrm{n} / \mathrm{a}$ & 0.2 & $\begin{array}{l}\text { Cutting force, } \\
\text { surface rough- } \\
\text { ness, surface } \\
\text { topography }\end{array}$ \\
\hline [129] (2020) & Inconel 718 alloy & Milling & MQL & $65,80,95$ & $0.1,0.15,0.20$ & 0.4 & $\begin{array}{l}\text { Surface roughness, } \\
\text { surface topogra- } \\
\text { phy, microhard- } \\
\text { ness, residual } \\
\text { stress }\end{array}$ \\
\hline
\end{tabular}

Braga et al. [121] studied the use of diamond-coated tools on drilling of aluminum-silicon alloy (A356) with MQL and flooded cooling techniques. It was concluded that MQL produced better performance in terms of surface roughness and tool life. Khan et al. [122] concluded in their experiment of the MQL lubrication technique on AISI 9310 alloy steel turning where MQL improved overall machinability, decreased cutting temperature, reduced tool flank wear which results in better tool life, and provided better end surface finishes compared to dry and flooded machining. Moreover, Gutnichenko et al. [124] studied the effect of MQLassisted machining performance on Alloy 718 turning. They noticed effective improvement in tool life, surface finish, and machining stability under MQL machining. Joshi et al. [123] 
conducted experiment involving performance comparison of dry, flooded, and MQL turning operations on Incoloy 800. The results showed in Fig. 31 that in MQL cooling condition provided minimal surface roughness value and noticeable gain in tool life of the uncoated tungsten carbide tool.

Moreover, Nagaraj et al. [126] established that the MQL technique was considered as an alternative cooling delivery method for process performance in carbon fiber-reinforced polymer (CFRP) drilling besides dry and cryogenic environments. They concluded in the study that the MQL method was able to reduce the delamination factor at the drilled hole entrance and exit while producing higher accuracy hole diameter compared to dry machining. Yıldırım et al. [127] compared the performance of MQL, cryogenic cooling, and cryoMQL cooling on tool life, surface roughness, and chip morphology of nickel-based 625 alloy machining as shown in Fig. 32. It revealed that the significant reduction of surface roughness, cutting temperature, and tool degradation were recorded in the experiment performed under cryoMQL.

$\mathrm{Ni}$ and Zhu [128] investigated the machining characteristic of TC4 alloy under ultrasonic vibration-assisted milling (UVAM) and economical-environmental MQL technology. The results showed that UVAM-MQL produced improved surface roughness by 10 to $30 \%$ and reduction of cutting force by 30 to $55 \%$ as compared to UVAM. De Oliveira et al. [125] also studied the influence of cutting fluid applications under dry and pulsed MQL delivery on the surface quality of micromilled slots on Inconel 718 alloys. Conclusions were made where surface roughness was significantly improved from MQL coolant delivery compared to dry machining by approximately 60\% which is shown in Fig. 33.

Zahoor et al. [129] studied the sustainability assessment of cutting fluids under dry, flooded, and MQL cooling approaches through comparative surface integrity evaluation of Inconel 718 milling. Dry milling, mineral oil-based flooded lubrication, and synthetic vegetable ester biodegradable oil-flooded lubrication were deployed to find their impacts on surface roughness, surface topography, residual stress, microhardness, and microstructures. They concluded that the biodegradable oil-based MQL approach on nickel-based alloys had improvements in surface integrity and microhardness over dry milling and mineral oil-based milling.

\subsection{MQL machining of titanium alloys}

In recent years, researchers had been investigating the applications of MQL machining in titanium alloys to reduce cost, usage of coolant, and sustainability of the method [135-137]. Table 4 shows the summary of recent journals published regarding the usage of the MQL cooling technique in the machining of titanium alloys.

A study on microdrilling performance with dry, wet, and MQL cutting fluid delivery methods was performed by Davis et al. [138]. They found in their research that ionic liquid-based MQL successfully improved tool life by $60 \%$ when compared to dry machining during commercially available grade 2 pure titanium turning. Qin et al. [140] found that MQL was able to improve tool life by up to $88 \%$ while obtaining low cutting temperature and good surface finish during turning of TC11 titanium alloy as shown in Fig. 34. MQL was opted for less cutting fluid utilization while still being able to perform similarly to flood cooling.

Venkata Ramana [139] performed a study on the effect of cutting parameters on the surface roughness during titanium alloy turning under dry, flooded, and MQL conditions. It was concluded that MQL showed superior results in terms of cutting performance when compared to dry and flooded machining conditions. In another study, Niketh et al. [98] concluded that the cutting thrust force was reduced effectively by $15-19 \%$ in MQL machining as compared to flooded machining. Both MQL and flood machining allowed the reduction in tool-workpiece contact length and chip removal and improved the lubrication effect at the cutting
Fig. 31 a, b Surface Roughness and Tool Wear Performance of Dry, Flooded and MQL Cooling Turning Operation on Incoloy 800 [123]
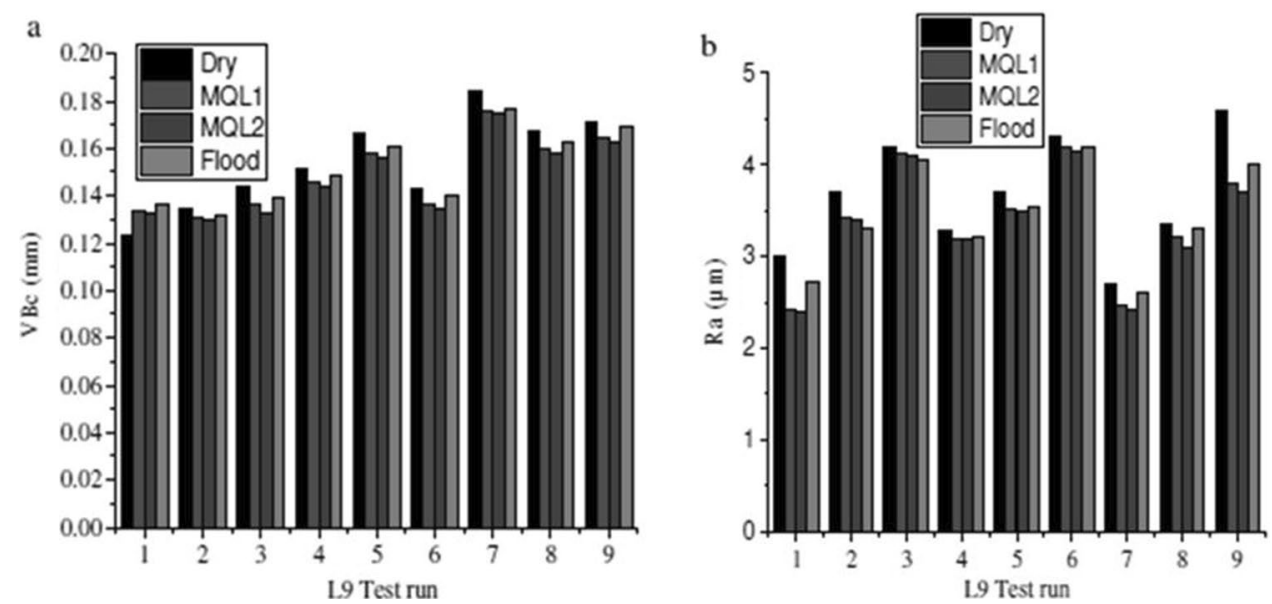


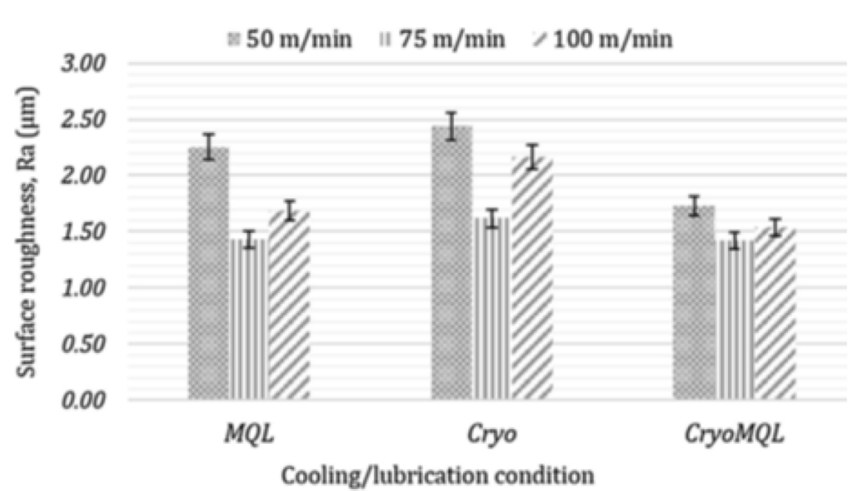

a)

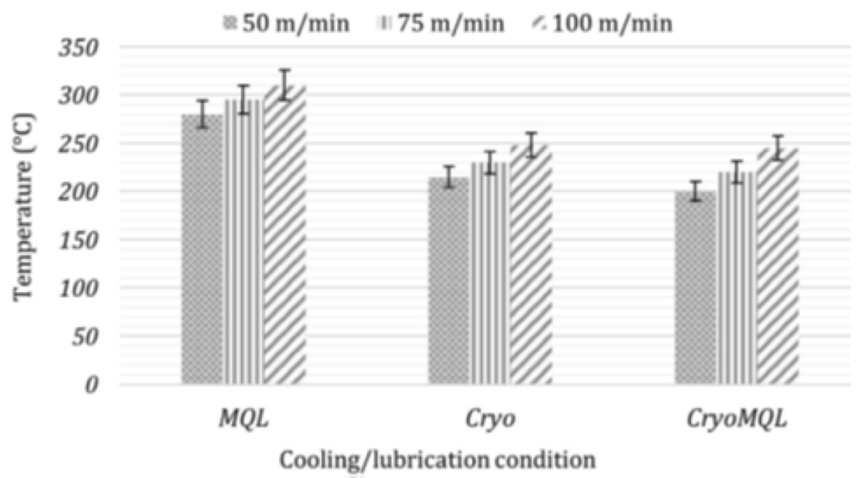

b)

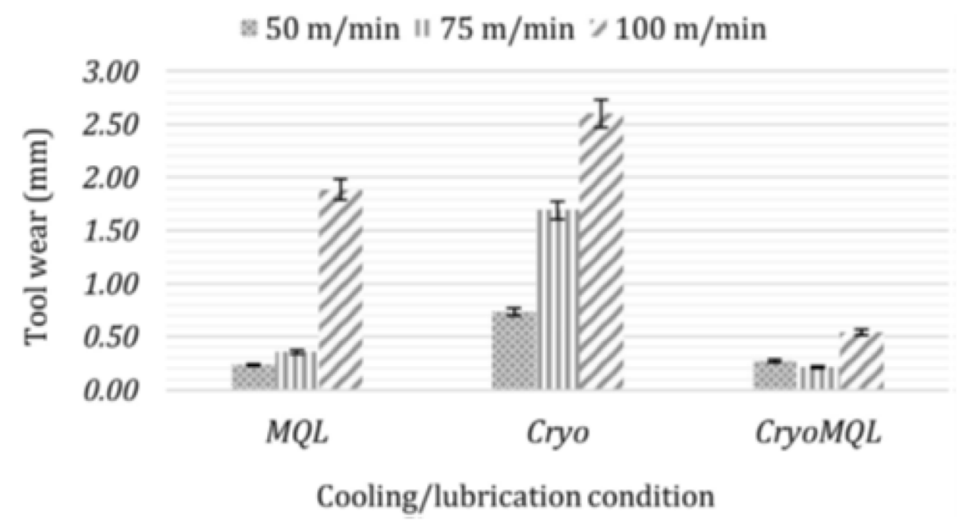

c)

Fig. 32 Machining performance comparison between MQL, cryo, and cryoMQL for $\boldsymbol{a}$ surface roughness, $\boldsymbol{b}$ cutting temperature, and $\boldsymbol{c}$ tool wear [127]

Fig. 33 Surface integrity of micromilled slots on Inconel 718 under $\boldsymbol{a}$ dry machining and $b$ MQL coolant [125]

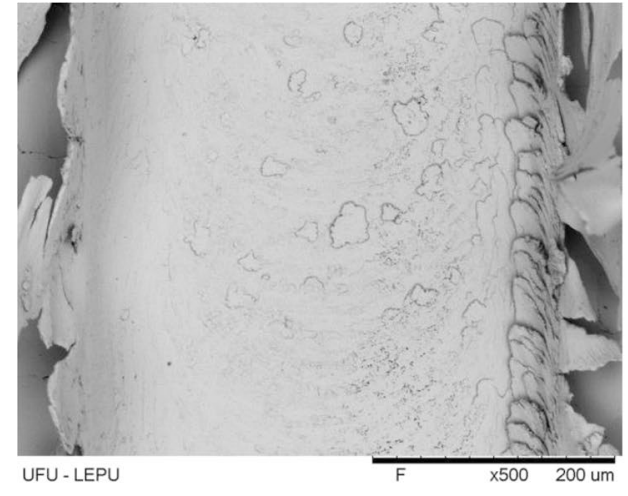

a)

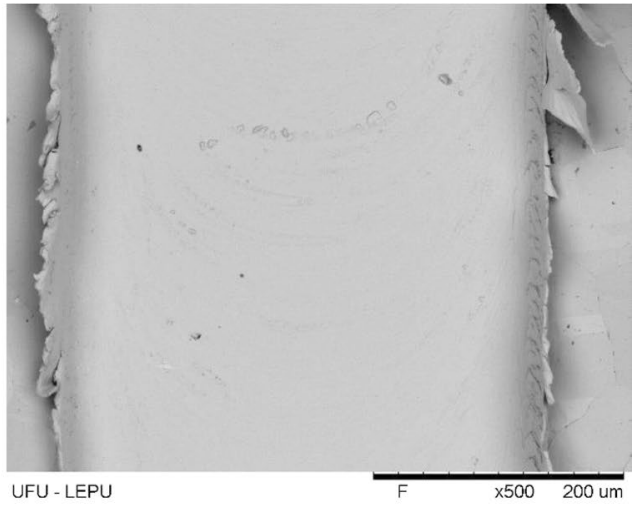

b) area. However, MQL was opted where energy consumption in terms of cutting fluids was minimized and sustainable machining is achieved. Moreover, Sartori et al. [49] concluded that solid lubricant-assisted MQL machining were able to effectively reduce crater wear and nose wear of cutting inserts and best surface roughness were achieved as shown in Fig. 35.
Khatri and Jahan [141] investigated the effect of dry, flood, and MQL conditions on tool wear in machining of titanium alloy and stated that MQL performed the best in terms of tool wear. A study by Shokrani et al. [52] on end milling machining of grade 5 titanium alloy using flooded, MQL, and hybrid cryogenic MQL conditions with coated solid carbide tools showed promising results in tool life improvement and surface finish due 
Table 4 Process parameters used during MQL machining of titanium alloys using various operations

\begin{tabular}{|c|c|c|c|c|c|c|c|}
\hline Ref & Material & $\begin{array}{l}\text { Machining } \\
\text { process }\end{array}$ & Lubrication & $\begin{array}{l}\text { Cutting speed }(\mathrm{m} / \\
\mathrm{min})\end{array}$ & $\begin{array}{l}\text { Feed rate }(\mathrm{mm} / \\
\mathrm{min})\end{array}$ & $\begin{array}{l}\text { Depth of cut } \\
(\mathrm{mm})\end{array}$ & Responses \\
\hline [138] (2015) & $\begin{array}{l}\text { Grade } 2 \text { titanium } \\
\text { alloy }\end{array}$ & Turning & MQL & 120 & 0.05 & 0.1 & $\begin{array}{l}\text { Cutting force, tool } \\
\text { wear, surface } \\
\text { roughness }\end{array}$ \\
\hline [139] (2016) & Ti6Al4V alloy & Turning & MQL & $63,79,99$ & $\begin{array}{l}0.206,0.274 \\
0.343\end{array}$ & $0.6,1.0,1.6$ & Surface roughness, \\
\hline [140] (2016) & TC11 alloy & Turning & MQL & 80 & 0.1 & 0.75 & $\begin{array}{l}\text { Cutting force, } \\
\text { machining tem- } \\
\text { perature, surface } \\
\text { roughness }\end{array}$ \\
\hline [49] (2018) & $\begin{array}{l}\text { Ti6Al4V ELI } \\
\text { alloy }\end{array}$ & Turning & MQL & 80 & 0.2 & 0.25 & $\begin{array}{l}\text { Tool wear, surface } \\
\text { roughness }\end{array}$ \\
\hline [98] (2018) & Ti6Al4V alloy & Drilling & MQL & 60 & 0.07 & $\mathrm{n} / \mathrm{a}$ & $\begin{array}{l}\text { Coefficient of fric- } \\
\text { tion, tool wear, } \\
\text { drilling thrust } \\
\text { force, drilling } \\
\text { torque }\end{array}$ \\
\hline [141] (2018) & Ti6Al4V alloy & Milling & MQL & 50 & $0.1,0.3,0.5$ & $0.2,0.3,0.4,0.5$ & Tool wear \\
\hline [142] (2019) & $\begin{array}{l}\text { Ti6Al4V ELI } \\
\text { alloy }\end{array}$ & Turning & MQL & $55,80,105$ & 0.1 & 1.0 & $\begin{array}{l}\text { Surface rough- } \\
\text { ness, machining } \\
\text { temperature, chip } \\
\text { morphology, tool } \\
\text { wear }\end{array}$ \\
\hline [143] (2019) & Ti6Al4V alloy & Turning & MQL & $60,120,180,240$ & $0.05,0.10$ & 0.25 & Tool wear \\
\hline [144] (2020) & $\begin{array}{l}\text { CFRP/Ti6Al4V } \\
\text { alloy }\end{array}$ & Drilling & MQL & $15,30,45,60$ & $\begin{array}{r}0.025,0.050 \\
0.075,0.100\end{array}$ & 1.5 & $\begin{array}{l}\text { Drilling force, } \\
\text { drilling torque, } \\
\text { surface rough- } \\
\text { ness }\end{array}$ \\
\hline [145] (2020) & Ti6Al4V alloy & Milling & MQL & $\begin{array}{l}23.6,31.4,39.3 \\
47.1,55.0\end{array}$ & $30,60,90$ & 0.075 & $\begin{array}{l}\text { Tool wear, surface } \\
\text { roughness, } \\
\text { residual stress }\end{array}$ \\
\hline
\end{tabular}

Fig. 34 a, b Tool life and surface roughness improvement of MQL over dry machining [140]

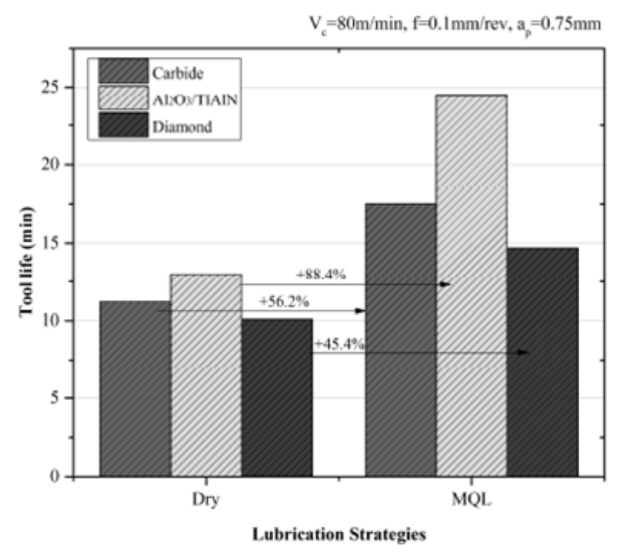

a)

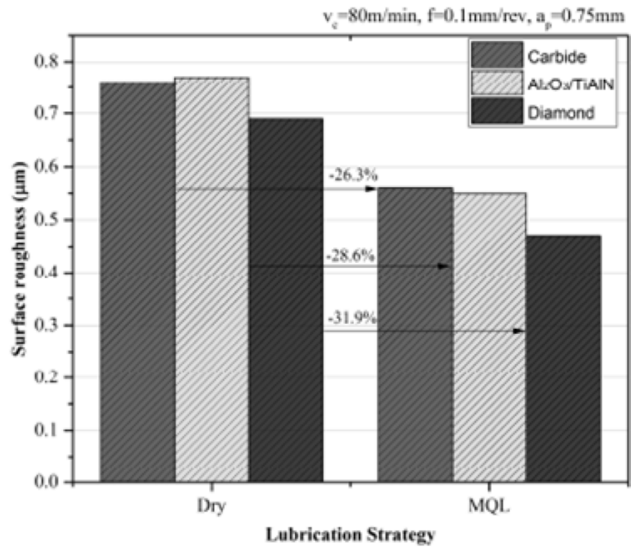

b) to sufficient lubrication which reduced friction wear and adhesion. Rahman et al. [142] reported that a nanofluid-aided MQL technique reduced overall tool wear of the cutting inserts during biomedical grade titanium alloy turning. An et al. [6] performed a surface roughness and tool life analysis of titanium alloy side milling under dry, flooded, and MQL techniques and they concluded that MQL lubrication significantly improved tool wear and machinability. Flank wear, rake wear, formation of built-up edges, and chip adhesion on the cutting tool were reduced under the MQL lubrication method as shown in Fig. 36. 
Fig. 35 a, b Tool flank wear comparison between dry machining and MQL-assisted machining [49]

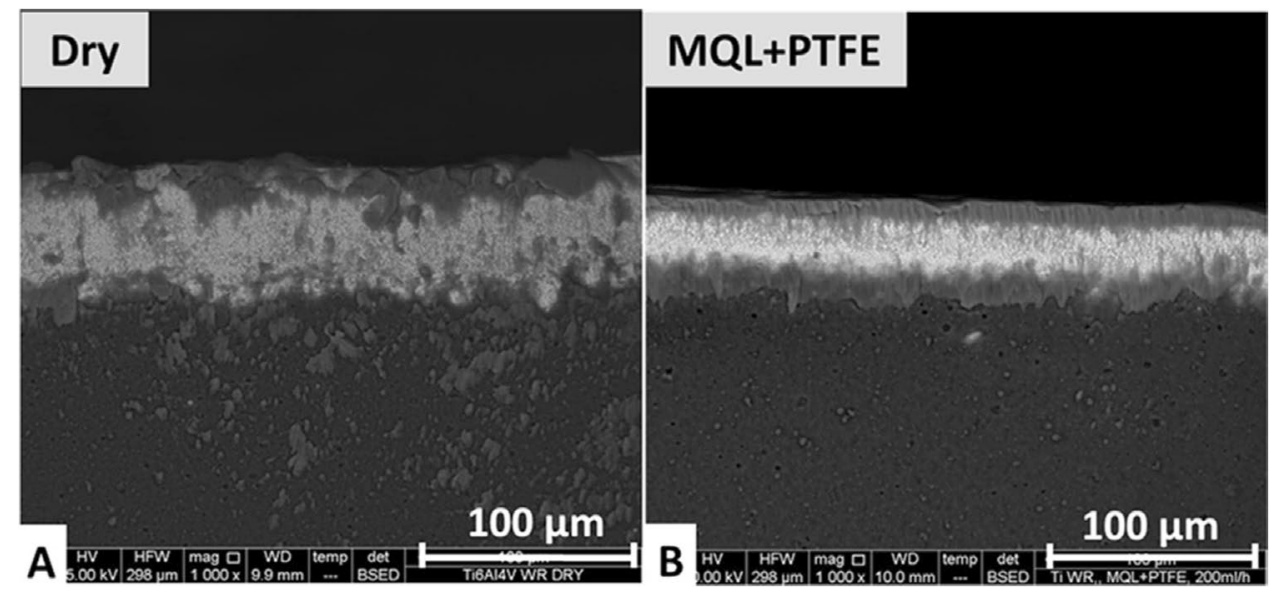

lubrications were able to reduce the cutting tool radius increment rate and improve flank wear by $26.2 \%$ compared to dry machining with the increase in cutting speeds and constant feed rate. Improvement on surface roughness and tool micromachined additive manufactured titanium alloy under dry and MQL conditions. They concluded that MQL
On the other hand, Khaliq et al. [145] performed a tool wear, surface quality, and residual stress analysis on
Tooth 1
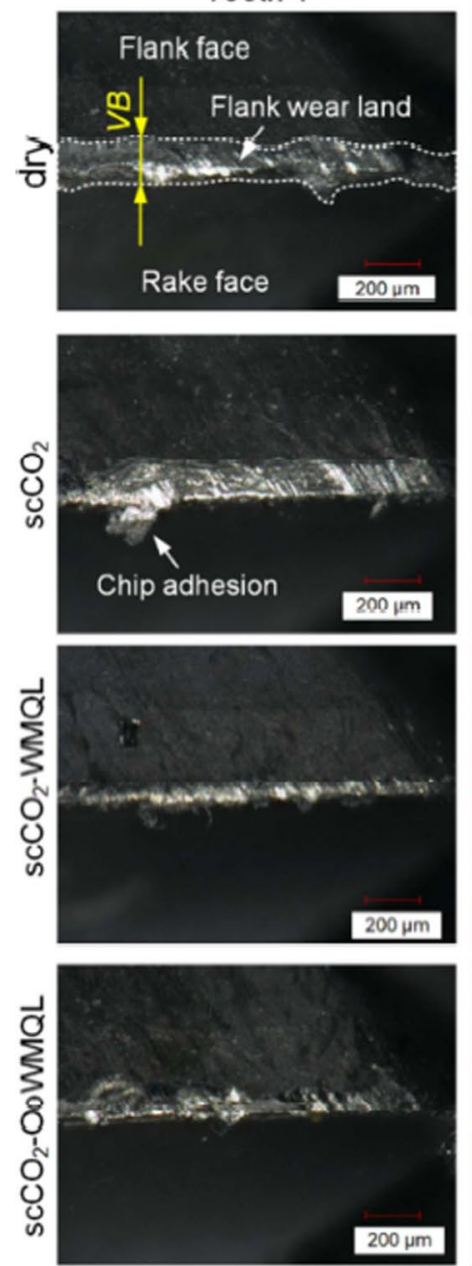

Tooth 2
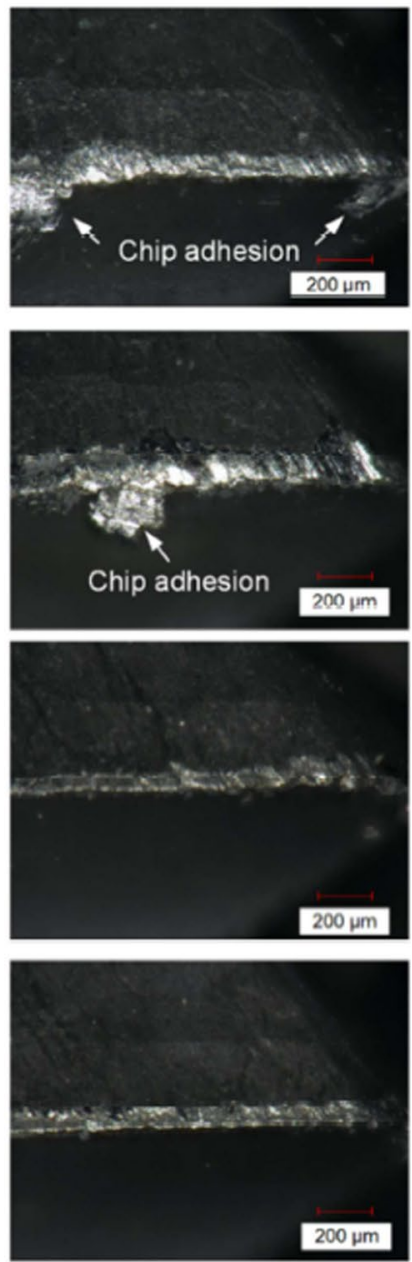

Tooth 3
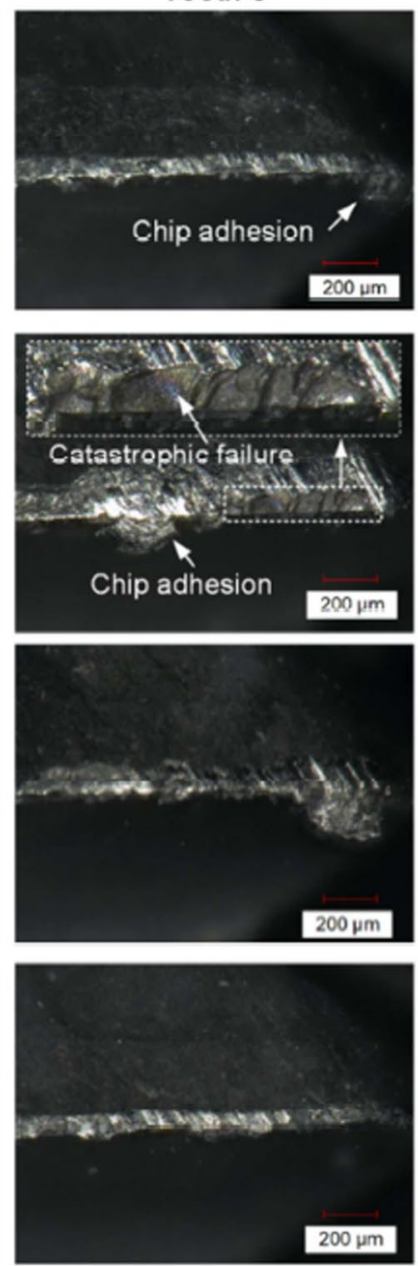

Tooth 4
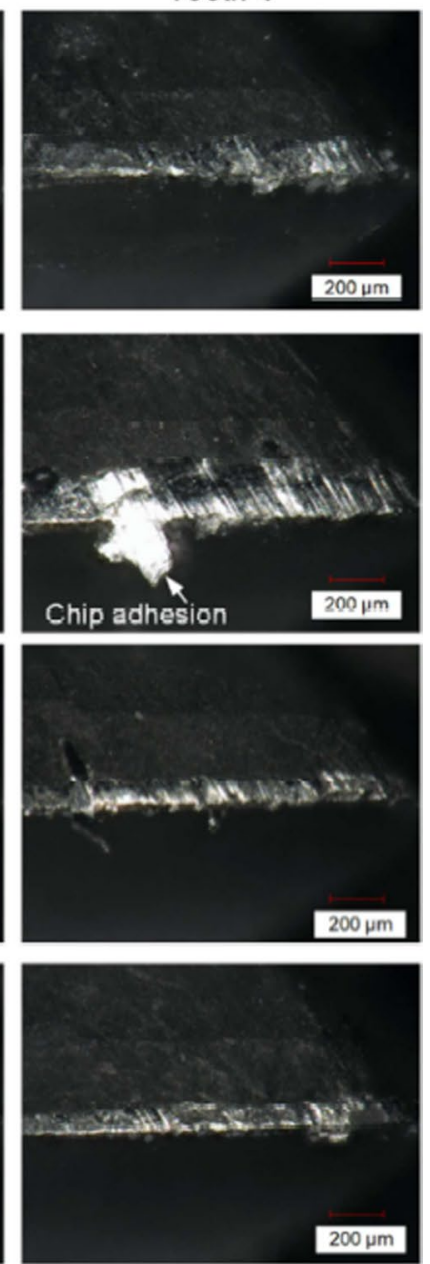

Fig. 36 Microscope view on tool wear comparison between dry and mql milling of Ti6Al4V [6] 


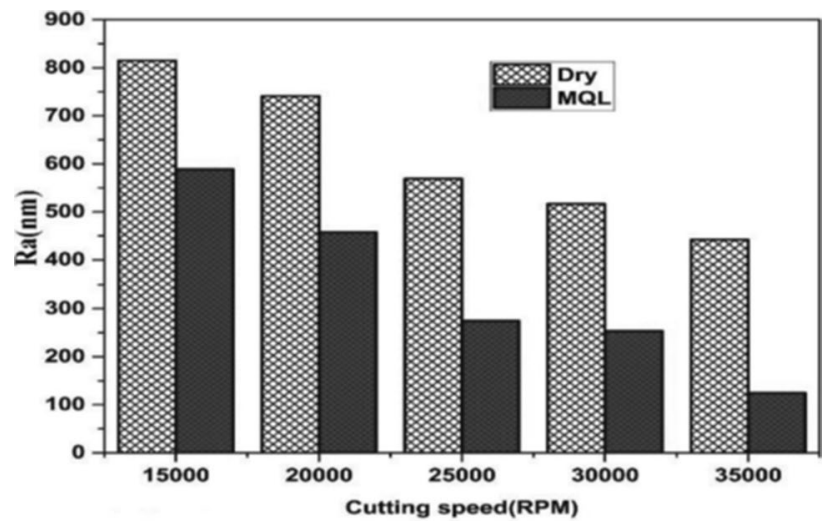

Fig. 37 Surface roughness performance between dry and MQL machining [145]

diameter reduction were also achieved under MQL lubrication environment which is shown in Fig. 37. In a nutshell, most researchers agreed that applications of MQL lubricant delivery during the machining of titanium alloys is beneficial and compatible for improved machinability and tool life while achieving desired surface roughness.

Da Silva et al. [143] studied the turning of titanium alloy under dry, jet, and MQL cooling methods using synthetic polycrystalline diamond (PCD) and cement carbide
(H13A) tools to investigate the wear mechanisms. The authors found that the MQL cooling technique produced better machining performance and improved cutting tool life at different cutting speeds and feed rates in comparison to dry turning which is shown in Fig. 38.

Xu et al. [144] investigated the drilling performance of carbon fiber-reinforced polymer (CFRP) laminated titanium alloy plates under dry and MQL conditions. MQL coolant was delivered at $15 \mathrm{~mL} / \mathrm{h}$ flow rate via compressed air pressure of $0.6 \mathrm{MPa}$ through the spindle system of the drilling bits. The authors concluded that MQL condition was able to significantly reduce drilling torque and energy consumption due to reduction of frictional force at the tool-workpiece interface. MQL condition also improved surface finish of the composite holes and suppressed burr formation on the workpiece.

\section{Types of cutting fluids}

\subsection{Synthetic/commercial oil as cutting fluid/ lubricant during machining}

Most manufacturing industries demand both high productivity and profit. High productivity can be achieved by using better machining techniques and optimum machining
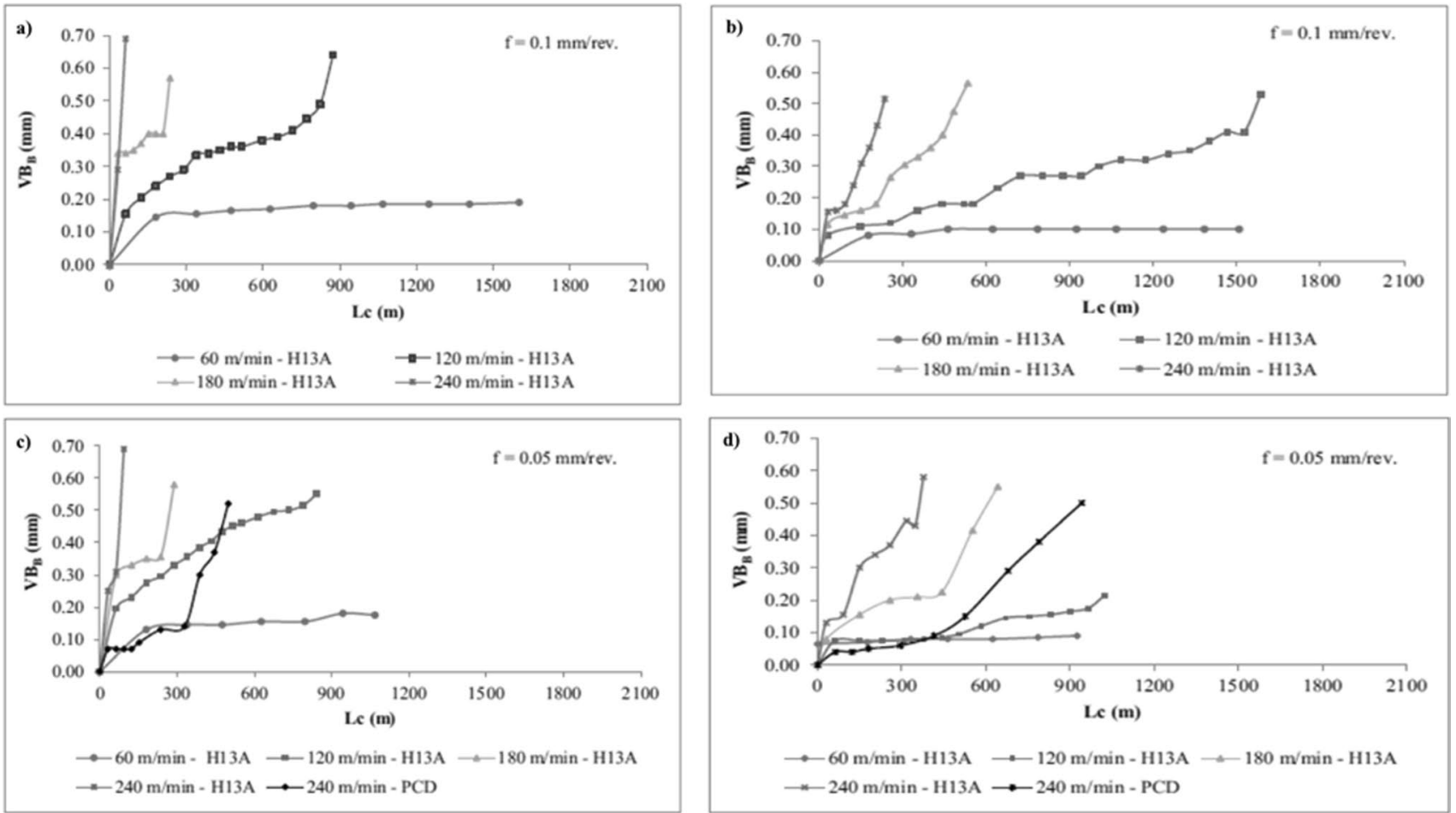

Fig. 38 Flank wear (VBB) of cemented carbide (H13A) and PCD tools in function to the length of cut in dry condition (a, b)) and MQL condition $(\mathbf{c}, \mathbf{d}))$ with feed rates of 0.1 and $0.05 \mathrm{~mm} / \mathrm{rev}$ [143] 
parameters. On the other hand, high profitability can only be achieved by ideal use of resources and maintaining low cost of production. Machining coolant accounts for around $10-17 \%$ of the total manufacturing cost which is shown in pie chart of Fig. 39. Therefore, the optimum use of cutting fluids becomes priority to minimize the total cost in manufacturing industries [91]. Generally, a water-soluble-based oil or chemically synthesized oil is used as a coolant to cool and lubricate at the material-tool interface[146]. These advantages make it widely usable in various industrial applications. Therefore, many researchers are continuously investigating the use of coolants and lubricants to enhance the machining performances under different coolant delivery methods.

Lubrication performance of diamond nanoparticles mixed with synthetic oil on steel machining were investigated by

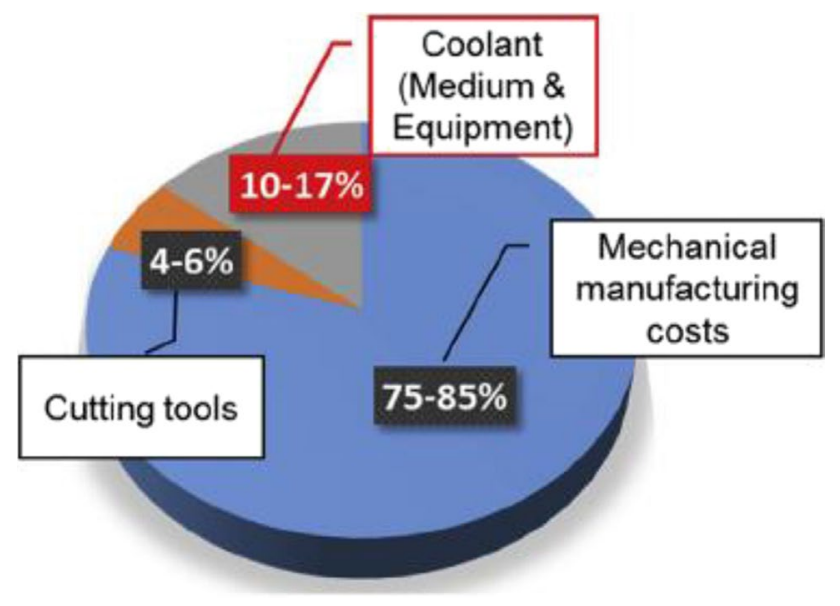

Fig. 39 Numerical proportions of manufacturing costs [91]
Raina and Anand [147] with different concentration of nanoparticles in addition to PAO oil. The study revealed that the addition of $0.2 \mathrm{wt} \%$ of diamond nanoparticles to PAO synthetic oil was able to substantially reduce coefficient of friction and adhesion wear on machining tools due to the reduction of sliding contacts between tool-workpiece interface and smoothening of sharp asperities. In another study by Lopes et al. [148] on the application of wheel cleaning system during alumina grinding under semi-synthetic oil MQL delivered through air jet showed that flooded machining provided the optimal experimental results. However, the delivery of the semi-synthetic oil under MQL at air jet angle of $30^{\circ}$ showed similar results to flooded cooling, with the increase of grinding wheel diameter by $83 \%$ and improvement of surface roughness and power consumption by $53 \%$ and $22 \%$ respectively. De Oliveira et al. [149] studied the influence of graphene platelet concentration in semi-synthetic oil on the grinding performance of Inconel 718 alloy using dry, flooded, and MQL techniques. The addition of graphene of $0.05 \%$ in the semi-synthetic emulsifiable Vasco 7000 oil performed the best in terms of surface roughness under MQL condition compared to dry and flooded machining as shown in Fig. 40.

Rajeshkumar and Ramesh [150] performed an investigation on design and optimization of machining parameters of MQL titanium alloy milling under dry, water-based MQL (MQL-W), vegetable-castor oil-based MQL (MQL-V), and synthetic ester oil-based MQL (MQL-S). The effect of feed rate and cutting speed on surface roughness, tool wear, and coefficient of frictions were also investigated with the combinations of the lubrication techniques. They found that the combinations of MQL-S, $0.4 \mathrm{~mm} / \mathrm{rev}$ feed rate, and cutting speed of $25 \mathrm{~mm} / \mathrm{min}$ were able to generate the optimum machining performance in terms of cutting force, surface
Fig. 40 Surface roughness of Inconel 718 after grinding under different cooling lubrication conditions [149]

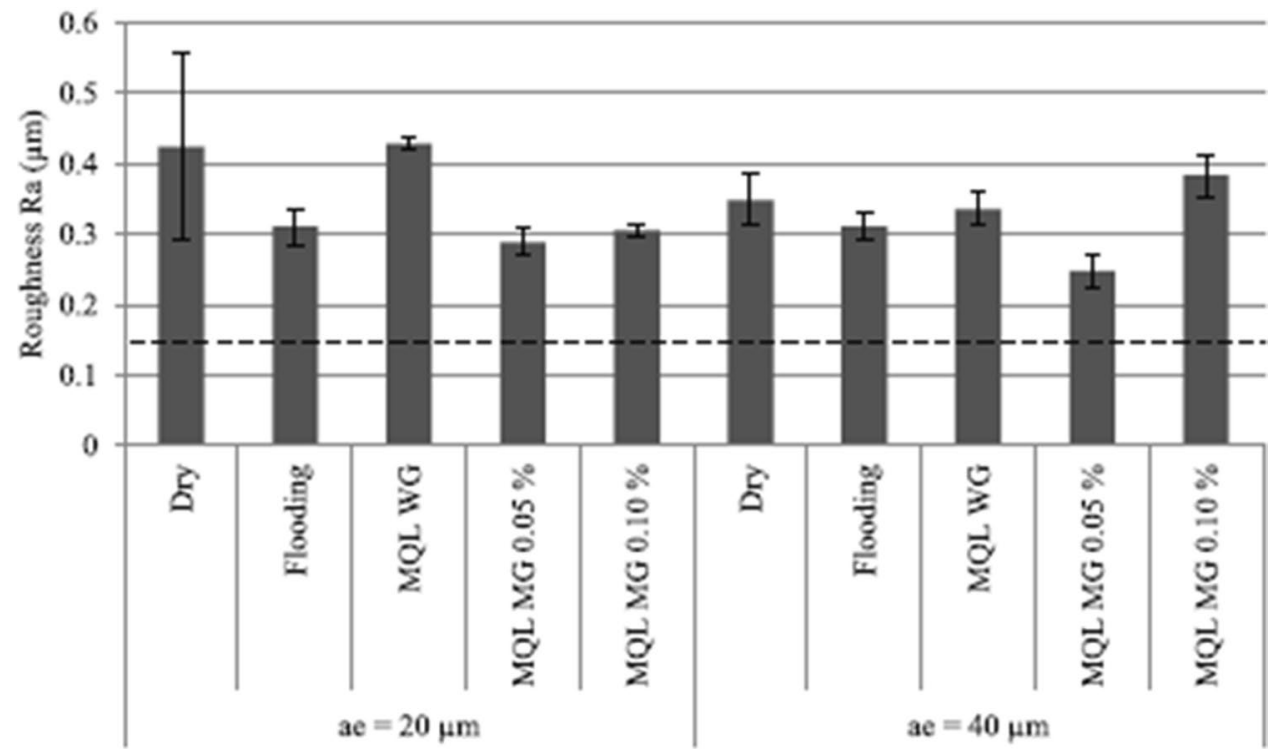


roughness, tool wear, and coefficient of friction. Moreover, Liu et al. [146] studied a performance evaluation of blended castor oil and ethanol under MQL delivery for AISI 304 steel. Surface roughness, tool wear, and surface hardness analyses were performed under the comparison of dry, flooded, castor oil MQL (VMQL), ethanol MQL (EMQL), and blended coolant (BMQL) methods. They found that BMQL reduced overall surface roughness by more than $4.5 \%$ in comparison to other cooling methods. It was also found that BMQL reduced the flank wear and crater wear of the carbide tool by $7.72 \%$ as shown in Fig. 41.

De Moraes et al. [151] studied the performance of two types of commercially available cutting fluids in pure form and diluted form for the grinding process of SAE 52100 steel under the MQL cutting fluid delivery technique. Different ratios of fluid dilutions were used, namely 1:0 (pure oil), 1:1 (50\% water), 1:3 (75\% water), and 1:5 (83\% water) for MQL fluid system, while 1:32 (97\% water) dilution of cutting fluid was used for flooded system as performance comparison. The authors concluded that the MQL system was viable as an alternative method of coolant delivery to replace flood coolant system due to the factor of extremely low amount of coolant required and ease of disposal of contaminated cutting fluids. The author also found that increase of water content in the diluted oil (83\% water content) improved the surface quality of the workpiece and reduced the temperature, wheel clogging, scratches, plowing, and rubbing during machining process.

Conventional cutting fluids are effective ways to cool and lubricate the cutting zone; however, they also result in several ecological problems. One of which are they often generates airborne mists, smoke, and other particles in the workshop's atmosphere. Due to the toxicity nature of the mists, conventional cutting fluids create health problems for the machining operators and lead to environmental pollution. Exposure to conventional cutting fluid had resulted in $80 \%$ of occupational infection among the contractors [152]. The potential severe health problems including respiratory diseases, lung cancer, genetic disease, and dermatological problems are suffered by machine operators who frequently expose to conventional cutting fluids [153]. According to report by the International Agency for Research on Cancer (IARC), petroleum-based cutting fluids lead to occupational skin cancer as it contains carcinogenic heterocyclic and polyaromatic rings [154]. Besides, the growth of bacteria in the cutting fluids obviously lead to the presence of microbial populations, especially endotoxins in the workplace atmosphere. Thus, proper disposal plan is needed for conventional cutting fluid due to their toxicity and nonbiodegradability traits. Due to above reasons, disposal cost of conventional cutting fluids is higher than the biodegradable cutting fluids. In fact, additional space is also required for storing and processing of contaminated conventional cutting fluids [155]. Moreover, for all the reasons mentioned, biodegradable fluids that are capable of being broken down by bacteria or microorganism without causing harm to the environment are generally chosen [156]. One of the suitable candidates for biodegradable cutting fluids is natural vegetable oil.

\subsection{Vegetable oil used as cutting fluid in machining}

Due to rising awareness and concern of health and safety, the demand for alternative replacement for conventional cutting lubricants for manufacturing industries has been ongoing for several years. Most of the oils used in MQL in recent days consist of synthetic fatty alcohols obtained from vegetables and mineral oils $[157,158]$. However, researchers have been indulging in various possibilities of lubricant types which contain biodegradable and stable characteristics under decent loads for longer service life of the lubricant. Based on the law restriction, the harmful contents of cutting oil are required to be minimized or removed to an acceptable level to reduce the adverse environmental impact. Therefore, sustainability and biodegradability of the cutting fluids are important aspects to be considered in manufacturing industries. One of the more viable options are natural oils, specifically vegetable oils such as coconut, rapeseed, sunflower, castor, canola, and palm oils due to their properties of having
Fig. 41 Comparison of machining performance of different metal-working conditions such as $\boldsymbol{a}$ surface roughness and $\boldsymbol{b}$ flank wear analysis [146]

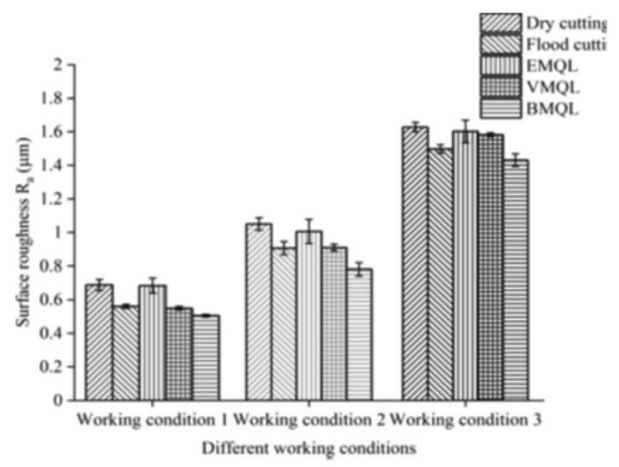

a)

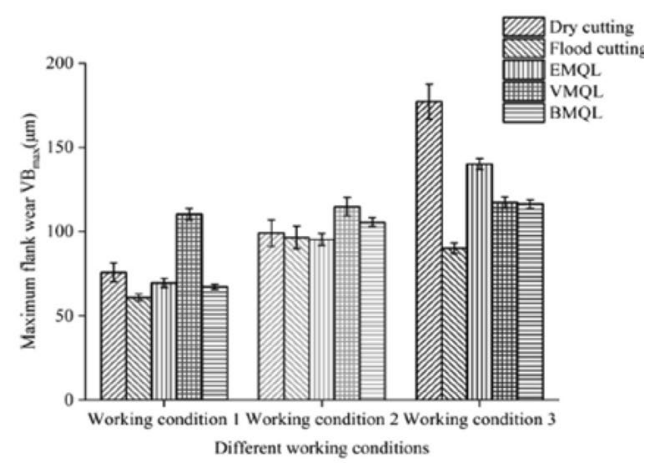

b) 
the ability to provide superior lubrications during metal and alloy machining while being biodegradable, non-toxic, and easily obtainable anywhere in the world. Table 5 shows the summary of works by various authors on the use of vegetable oil in machining.

Agrawal and Patil [160] reported that vegetable oil was a potential replacement of conventional cutting fluid on M2 steel machining under the MQL technique. Furthermore, they recommended that aloe vera oil was the most suitable vegetable oil as it produced better surface roughness and tool wear in steel machining while also being environmentally friendly. Ghatge et al. [161] concluded that coconut and neem oil demonstrated promising results in improving machinability of stainless steel, producing better surface roughness and lower tool wear when compared to mineral oil. Another study by Mahadi et al. [159] showed that boric acid-aided palm kernel oil yielded better surface roughness compared to conventional mineral-based oil in MQL turning of AISI 431 steel. They suggested that vegetable oil was able to reduce the environmental impact as well as the risk of health and safety of operators. As shown in Fig. 42, Fernando et al. [167] used coconut oil-based metal cutting fluids as MQL coolant in AISI 304 stainless steel turning. They determined that surface finish and tool wear were improved using coconut oil-based cutting fluid in comparison to standard emulsion mineral oil.

Moreover, Lal Virdi et al. [168] found that nanofluid vegetable oil MQL for Inconel 718 grinding performed the best with reference to surface roughness, machining energy, and coefficient of friction when compared to dry and flooded machining. Khunt et al. [169] concluded that vegetable oilbased MQL (sunflower oil) were able to effectively improve

Table 5 Process parameter used during MQL machining using vegetable oil-based cutting fluids

\begin{tabular}{|c|c|c|c|c|c|c|c|}
\hline Ref & Material & $\begin{array}{l}\text { Machining } \\
\text { process }\end{array}$ & Lubrication & $\begin{array}{l}\text { Cutting speed } \\
(\mathrm{m} / \mathrm{min})\end{array}$ & $\begin{array}{l}\text { Feed rate }(\mathrm{mm} / \\
\text { min) }\end{array}$ & $\begin{array}{l}\text { Depth of cut } \\
(\mathrm{mm})\end{array}$ & Responses \\
\hline [159] (2017) & AISI 431 steel & Turning & MQL & 150,200 & $0.16,0.24$ & $0.5,1.0$ & Surface roughness \\
\hline [160] (2018) & M2 steel & Turning & MQL & $\begin{array}{c}52.36,83.78 \\
130.90\end{array}$ & $0.18,0.27,0.36$ & $0.2,0.4,0.6$ & $\begin{array}{l}\text { Surface rough- } \\
\text { ness, tool wear }\end{array}$ \\
\hline [161] (2018) & $\begin{array}{l}\text { AISI } 2205 \text { stain- } \\
\text { less steel }\end{array}$ & Turning & MQL & $100,150,200$ & $0.1,0.2,0.3$ & $0.4,0.8,1.2$ & $\begin{array}{l}\text { Tool wear, surface } \\
\text { roughness, cut- } \\
\text { ting temperature }\end{array}$ \\
\hline [162] (2019) & $\begin{array}{l}\text { Ti-6Al-4V ELI } \\
\text { alloy }\end{array}$ & Grinding & Dry, MQL & 22 & 3000 & 0.1 & $\begin{array}{l}\text { Specific grinding } \\
\text { energy, coeffi- } \\
\text { cient of friction, } \\
\text { surface rough- } \\
\text { ness, grinding } \\
\text { forces }\end{array}$ \\
\hline [163] (2020) & Ti-6Al-4V alloy & EDM & Dielectric Fluid & - & - & - & Surface roughness \\
\hline [164] (2020) & AISI H13 steel & Grinding & MQL & 39.25 & 10 & 15 & $\begin{array}{l}\text { Surface rough- } \\
\text { ness, grinding } \\
\text { temperature, } \\
\text { grinding force, } \\
\text { specific energy. }\end{array}$ \\
\hline [165] (2020) & $\begin{array}{l}\text { SAE } 1045 \text { steel, } \\
6061-T 6 \text { alu- } \\
\text { minum }\end{array}$ & AFM & Abrasive Flow & - & - & - & Surface roughness \\
\hline [166] (2020) & $\begin{array}{c}\text { 7050-T7451 } \\
\text { aluminum }\end{array}$ & Milling & Wet & 150 & 0.012 & 0.060 & $\begin{array}{l}\text { Cutting force, tool } \\
\text { wear, surface } \\
\text { roughness }\end{array}$ \\
\hline
\end{tabular}

Fig. 42 a, b Surface roughness performance of coconut oil MQL delivery on AISI 304 stainless steel turning [167]
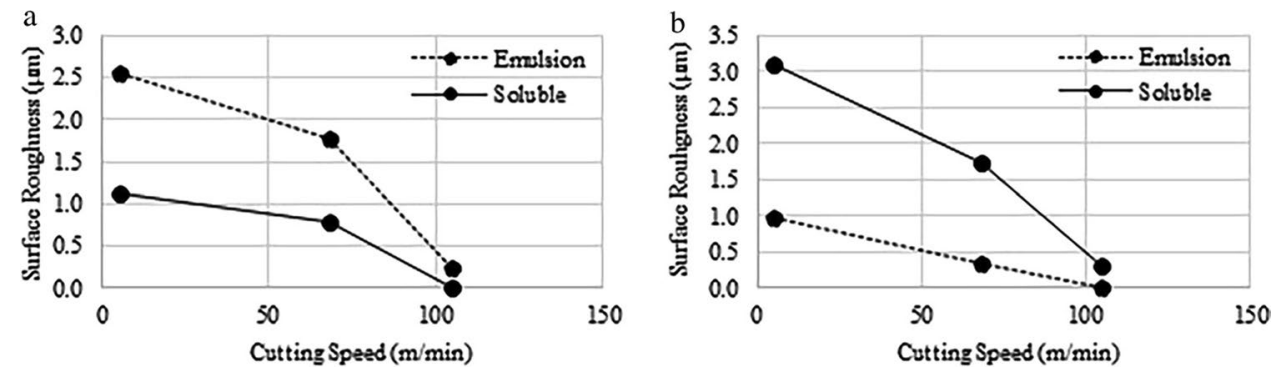
thrust force, torque, and surface roughness at higher cutting speed during drilling as shown in Fig. 43. Moreover, they reported that vegetable oil-based metal-working fluids have the potential as an effective alternative metal-working fluid over castor oil for flood cooling or MQL that can effectively enhance machining performance during drilling operations.

In terms of vegetable oil application in titanium alloy machining, there are several investigations performed by various authors. For example, Deiab et al. [170] found that vegetable oil specifically rapeseed oil in both MQL and MQCL setups was the most sustainable option over synthetic coolants. Rao et al. [171] used coconut oil in the development of novel cutting tool in titanium alloy turning where positive results were obtained in terms of tool wear, cutting temperature, and surface roughness. Moreover, Singh et al. [162] found that nanographene additive-aided canola oil reduced grinding energy and achieved green manufacturing due to its high content of fatty acids, high heat capacity, and decent fluid viscosity. The usage of jojoba oil with the addition of nanoparticles in Ti-6Al-4V alloy hard turning was investigated by Gaurav et al. [172] where conclusions were made that jojoba oil showed promising results in cutting force, surface roughness and tool wear improvements. Singaravel et al. [163] investigated the use of vegetable oils such as sunflower, canola, and jatropha oils as dielectric machining fluids in titanium alloy EDM machining. Conclusion was made that vegetable oil was suitable replacement for conventional dielectric fluids with similar properties. Moreover, vegetable oils were eco-friendly and biodegradable, showing sustainable machining. Furthermore, Awale et al. [164] used groundnut oil as MQL lubricant in AISI H13 steel grinding to determine its effect on grinding temperature, surface roughness, specific energy, and grinding force. At $4 \mathrm{bar}$ of pressure, $200 \mathrm{ML} / \mathrm{H}$ flow rate and diameter of $50 \mathrm{~mm}$ settings showed the best performance in the grinding process. Munhoz et al. [165] analyzed the surface roughness (Ra, Rq, and Rz) of aluminum 6061-T6 and medium carbon

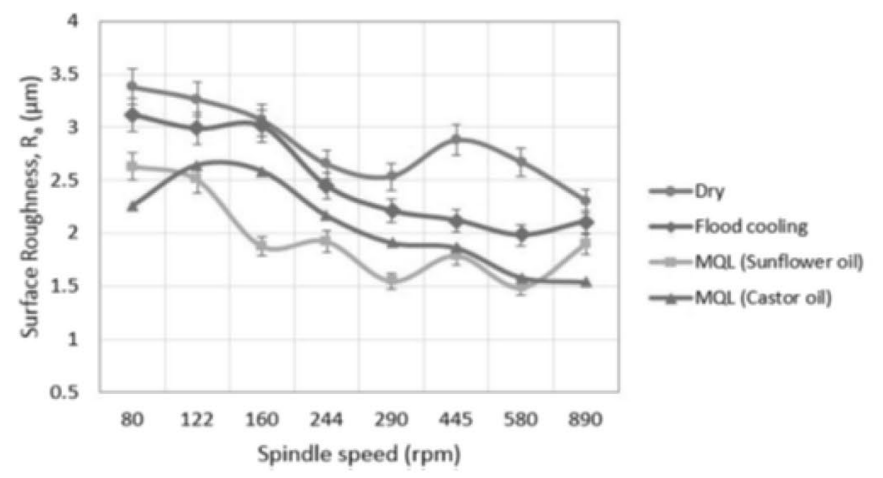

a) steel SAE 1045 workpieces under abrasive flow machining process using oiticica vegetable oil with mixture of abrasive particles. They found that the developed paste based on the oiticica oil used on the machining of steel and aluminum was able to reduce the surface roughness and chip accumulation.

In another research completed by Chanes De Souza et al. [166], the authors studied the influence of fatty acid content in vegetable oil-based (VO) MWFs on the lubrication film formation in micromilling process of aluminum alloy. Higholeic fatty acid (HOFA) and mild-oleic fatty acid (MOFA) based sunflower oil were used in the micromilling process with the combination of cutting parameters of $150 \mathrm{~m} / \mathrm{min}$ cutting speed, $0.012 \mathrm{~mm} / \mathrm{z}$ feed per tooth, and $0.060 \mathrm{~mm}$ depth of cut. The authors concluded that HOFA produced better lubricating film which resulted in improved protection compared to MOFA. They also found that VO-HOFA and VO-MOFA showed similar tool wear performance and improved surface finish of micromilled aluminum alloy in comparison to commercial emulsion as shown in Fig. 44.

\subsection{Palm oil as MQL cutting fluid in metal machining}

Palm oil, commercially known as Elaesis quineenis, is one of the main agricultural crops produced in Malaysia which thrives in a hot tropical climate [173]. Therefore, due to the exquisite amount of oil palm crops, palm oil production has become Malaysia's largest export and production for decades. According to statistics, Malaysia exported a total of 17.3 million tonnes of the total world oil palm production in year 2020 and 18.4 million tonnes in the year 2019 as shown in Fig. 45. Therefore, Malaysia is known to be one of the largest palm oil production and export countries in the Southeast Asia region together with Indonesia [174]. Palm oil contains approximately $50 \%$ saturated fatty acids, $40 \%$ monosaturated fatty acids, and $10 \%$ polyunsaturated fatty acids. Palm oil and its components are generally used

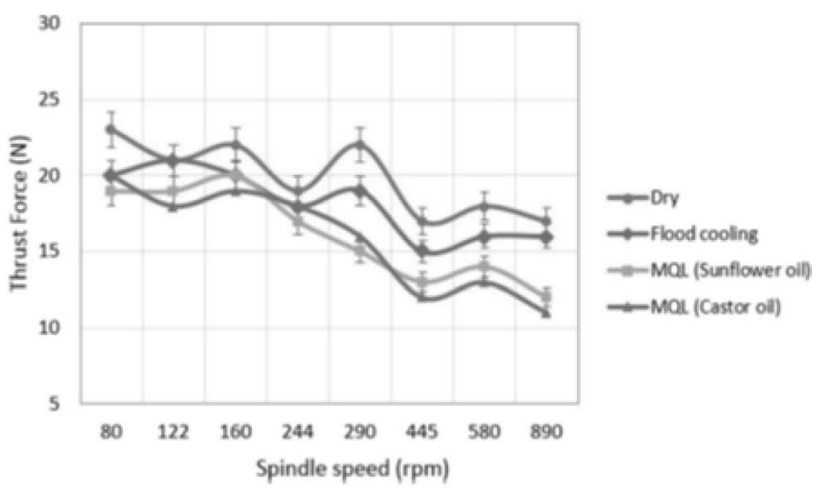

b)

Fig. 43 a, b Resultant surface roughness and thrust force from dry, flooded, synthetic oil MQL, and vegetable oil MQL [169] 
Fig. 44 Surface roughness of micromilled A17050-T7451 aluminum alloy using different lubricants [166]
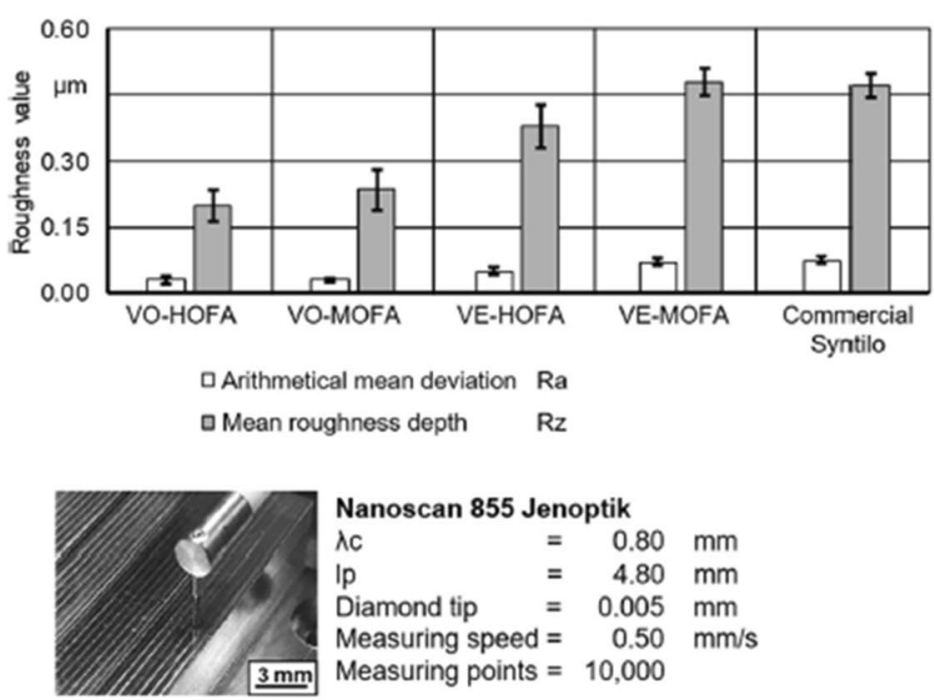

Nanoscan 855 Jenoptik

Ac $=0.80 \mathrm{~mm}$

Ip $\quad=4.80 \mathrm{~mm}$

Diamond tip $=0.005 \mathrm{~mm}$

Measuring speed $=0.50 \mathrm{~mm} / \mathrm{s}$

Measuring points $=10,000$
Machine tool

Wissner gamma 303 highperformance machine tool

\section{Cutting tool}

Cemented carbide micro end mill

Zecha 535.F2.100.200

$\mathrm{D}=1.00 \mathrm{~mm}$

\section{Material}

Al 7050-T7451 alloy

\section{Cutting strategy} Zig-zag

Cutting parameters
$n=47,750 \mathrm{rpm}$
$\mathrm{f}_{z}=0.012 \mathrm{~mm}$
$\mathrm{v}_{c}=150 \mathrm{~m} / \mathrm{min}$
$\mathrm{a}_{p}=0.060 \mathrm{~mm}$
$\mathrm{a}_{n}=40 \%$

in production of daily living product and foods such as vegetable-based cooking oil, soaps, shortenings, and confectionery products. The versatility and adaptability of palm oil to different applications are the result of its chemical composition [175].

In previous research works performed by various authors, palm oil had been proved to be a promising potential replacement to synthetic oils which is more superior to conventional cutting fluids in machining industries [177-180,181]. Palm oil is one of the recent choices from list of vegetable oils to be studied as potential low cost, efficient cutting fluids for MQL-assisted machining. It is considered an environmentally friendly vegetable-based oil with the high potential to be used as cutting fluid due to its high content of triglycerides and polarity which contribute to good heat absorption film for heat removal from tool workpiece area [182]. Rahim

\begin{tabular}{|c|c|c|c|c|}
\hline & \multicolumn{2}{|c|}{ Exports } & \multicolumn{2}{|c|}{ Imports } \\
\hline & 2020 & 2019 & 2020 & 2019 \\
\hline Jan & $1,213,539$ & $1,680,891$ & 85,033 & 81,477 \\
\hline Feb & $1,082,417$ & $1,324,615$ & 66,735 & 94,278 \\
\hline Mar & $1,184,702$ & $1,620,752$ & 79,216 & 131,242 \\
\hline Apr & $1,236,478$ & $1,654,499$ & 56,596 & 62,112 \\
\hline May & $1,369,351$ & $1,715,719$ & 37,101 & 61,789 \\
\hline Jun & $1,706,597$ & $1,397,140$ & 48,841 & 101,250 \\
\hline Jul & $1,783,284$ & $1,486,485$ & 52,691 & 40,069 \\
\hline Aug & $1,578,075$ & $1,736,300$ & 32,311 & 51,055 \\
\hline Sep & $1,612,155$ & $1,409,089$ & 48,273 & 71,112 \\
\hline Oct & $1,674,304$ & $1,641,973$ & 45,398 & 85,034 \\
\hline Nov & $1,303,271$ & $1,405,638$ & 112,663 & 74,684 \\
\hline Dec & $1,624,692$ & $1,396,157$ & 282,058 & 123,029 \\
\hline Jan-Dec & $17,368,865$ & $18,469,258$ & 946,917 & 977,131 \\
\hline
\end{tabular}

Fig. 45 Malaysia's monthly palm oil trade statistics 2020 [176] 
and Sasahara [135] reported that PO-MQL produced better overall performance in terms of preserving tool life in Ti alloys machining compared to synthetic oil. The utilization of PO-MQL allowed for lower generated temperatures and thrust forces due to formation of thin lubrication film from its triglyceride contents between the tool-workpiece interfaces. It was concluded that PO was a viable candidate for substitution of synthetic oil as MQL fluids due to its biodegradability and excellent lubrication performance. In another study done by Li et al. [183], it was concluded that PO-MQL was able to generate the lowest temperature and cutting forces which lead to tool life improvements due to the presence of unsaturated fatty acid and viscosity properties compared to other vegetable oils. A recent study by Sen et al. [184] on synergistic effect of silica nanoparticles and pure palm oil in the machining performance of Inconel 690 showed that $1 \%$ addition of silica deposits in palm oil (1\%MQNGL) was able to substantially improve surface roughness, reduce resultant cutting force and cutting temperature, and enhance tool life due to the formation of tribo-film between the tool-workpiece interface as shown in Fig. 46.

Sen et al. [185] investigated alumina-enriched palm oilbased MQL lubrication condition on the wear behavior of Ti-Al-N-coated solid carbide tools in end milling of Inconel 690 where $0.9 \%$ alumina-deposited palm oil (0.9\%-MAPO), flooded coolant, and pure palm oil (MPO) were used as metal-working fluid. They concluded that $0.9 \%$-MAPO were able to improve coated solid carbide tool wear by $19.35 \%$ over flooded cooling and $10.71 \%$ over MPO cooling respectively.

\section{Summary}

As machining represents a major part of manufacturing industries in terms of producing quality products, it involves the machine parameters, lubricants, and the environment. Due to the focus on ecological pollution and health and safety issues, manufacturing industries were required to implement environmentally friendly machining techniques in their operations. Therefore, minimum quantity lubrications have been gaining significant attention throughout the years due to its capability as a cooling delivery solution to enhance the heat transfer and lubrication performance for machining operations. This paper represents a comprehensive review of published articles concerning on the recent progresses on application of MQL in different metal machining techniques, the machining performance of MQL, and the sustainability characteristics of MQL lubrication delivery using synthetic oil and vegetable oil in various machining
Fig. 46 a-c Machining performance comparison between dry and MQL Inconel 690 machining [184]

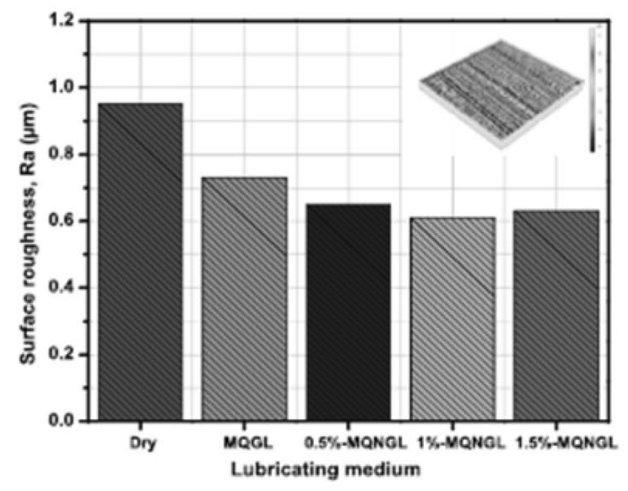

a)

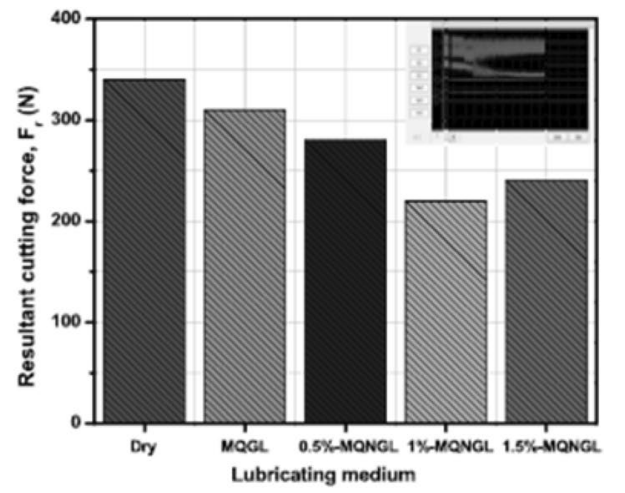

b)

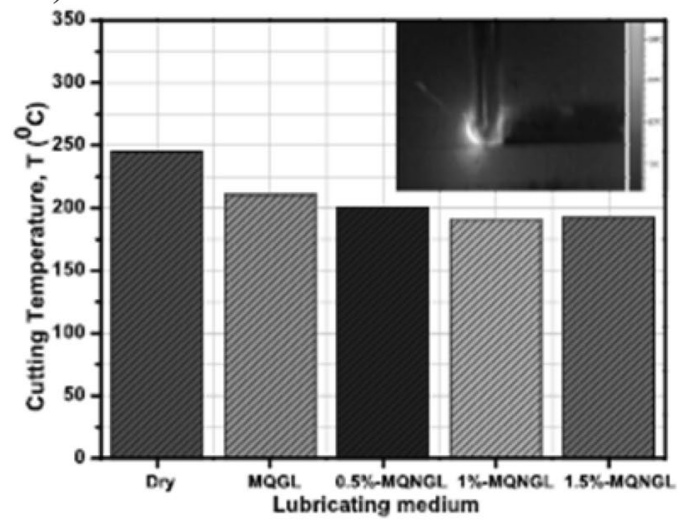

c) 
process such as drilling, milling, grinding, and turning. The summary is outlined as follows:

1. In terms of sustainable manufacturing, the MQL method shows significant improvements for manufacturing industries in terms of environmental friendliness and compliance to health and safety regulations. It is a more cost-efficient method of cooling and lubrication as a metal-working fluid, and it generally reduces the usage of coolants by more than half the amount used in flooded cooling as shown in Table 6. Due to excellent heat removal and dissipation capability of the MQL method, similar or lower resultant surface roughness and cutting temperature can be achieved under MQL environment with the combination of optimum machining parameters such as cutting speeds, feed rates, and depth of cuts as compared to dry and flooded machining conditions.

2. The natural properties of vegetable-based metal-working fluids provide similar or more superior lubrications during any metal, alloys, or hybrid composites machining due to its biodegradable, non-toxic, and easily disposable natures. These vegetable oils can also further enhance the effect of MQL delivery as a cost-saving and eco-friendly method of lubrication and cooling. A summarized view of usage of vegetable oil-based metalworking fluids in MQL machining is shown in Table 7.

3. Tool wears such as flank wear, crater wear, and built-up edges on cutting tools along with machining forces and coefficient of friction were significantly reduced by using minimum quantity lubrication due to better penetration of machining fluid at the tool-chip interaction zone.

4. The paper not only showed the potential advancements of MQL methods but also focused on using cryogenic liquids and vegetable-based oils in MQL delivery to improve the performance of various machining operations.

5. Palm oil has good potentials to be an alternative cutting fluid in MQL machining to the conventional and commercially available metal-working fluids. Table 8 summarizes the current usage of palm oil in machining processes as lubricant. However, it is noticed that there is a lack of research in using palm oil as cutting fluid which triggers the need of additional investigations to be done to further explore its capabilities.

Table 6 Benefits for using MQL cooling delivery methods in different machining operations

\begin{tabular}{|c|c|c|c|c|}
\hline References & Machined material & Machining process & Mode of lubrication & Findings \\
\hline Praveen et al. [105] & EN 47 chrome-vanadium steel & Turning & Dry, MQL & $\begin{array}{l}\text { MQL improved surface roughness by } 48 \% \\
\text { in comparison to dry machining }\end{array}$ \\
\hline Mishra et al. [104] & EN 24 high tensile steel & Turning & MQL & $\begin{array}{l}\text { MQL provided significant cooling and } \\
\text { lubrications resulting in improvement of } \\
\text { surface roughness and reduced machining } \\
\text { costs }\end{array}$ \\
\hline Abas et al. [118] & 6026-T9 aluminum & Turning & Dry, MQL & $\begin{array}{l}\text { Increase in tool life and better surface qual- } \\
\text { ity of machined workpiece under MQL } \\
\text { compared to dry machining }\end{array}$ \\
\hline Javidikia et al. [120] & 6061-T6 aluminum & Turning & Dry, wet, MQL & $\begin{array}{l}\text { Increased productivity and tool life and } \\
\text { improved surface roughness under MQL } \\
\text { coolant delivery }\end{array}$ \\
\hline Gutnichenko et al. [124] & Inconel 718 alloy & Turning & Dry, MQL & $\begin{array}{l}\text { Improvement of tool life, machining stabil- } \\
\text { ity, and surface finish of alloy }\end{array}$ \\
\hline Ni et al. [128] & TC4 alloy & Milling & MQL & $\begin{array}{l}\text { UVA-assisted MQL improved surface } \\
\text { roughness up to 30\% and machining force } \\
\text { up to 55\% while also reducing machining } \\
\text { time }\end{array}$ \\
\hline Shukla et al. [97] & 6061 aluminum & Drilling & Dry, wet, MQL & $\begin{array}{l}\text { Vegetable oil-based MQL improved surface } \\
\text { finish and tool wear over dry and wet } \\
\text { machining }\end{array}$ \\
\hline Khatri et al. [141] & Ti-6Al-4V titanium alloy & Milling & Dry, wet, MQL & $\begin{array}{l}\text { Significant improvement of edge chipping } \\
\text { and adhesion tool wear was observed } \\
\text { under MQL machining }\end{array}$ \\
\hline Xu et al. [144] & CFRP/Ti-6Al-4V Hybrid & Drilling & Dry, MQL & $\begin{array}{l}\text { MQL produced better geometrical accuracy } \\
\text { of drilled holes, while reducing energy } \\
\text { consumption, and better tool wear com- } \\
\text { pared to dry drilling }\end{array}$ \\
\hline
\end{tabular}


Table 7 Summary of vegetable oil-based cutting fluids in MQL machining

\begin{tabular}{|c|c|c|c|c|}
\hline References & Machined material & Machining process & Mode of lubrication & Findings \\
\hline Mahadi et al. [159] & AISI 431 steel & Turning & MQL & $\begin{array}{l}\text { Improvement of surface roughness by } \\
7.21 \% \text { using boric acid powder- } \\
\text { aided palm kernel oil compared to } \\
\text { conventional mineral-based oil }\end{array}$ \\
\hline Singh et al. [162] & Ti-6Al-4V ELI alloy & Grinding & MQL & $\begin{array}{l}\text { Machining performance under } \\
\text { nanoadditive-based canola oil } \\
\text { machining fluids was improved } \\
\text { over synthetic fluid-based MQL, } \\
\text { soybean, and olive oil-based MQL }\end{array}$ \\
\hline Gaurav et al. [172] & Ti-6Al-4V titanium alloy & Turning & Dry, MQL & $\begin{array}{l}\text { Nanoparticle-enhanced jojoba } \\
\text { vegetable oil showed significant } \\
\text { improvement reduction of cutting } \\
\text { force, surface roughness, and tool } \\
\text { wear ranging from } 35 \text { to } 47 \% \text { in } \\
\text { comparison to commercially avail- } \\
\text { able mineral oil }\end{array}$ \\
\hline Virdi et al. [168] & Inconel 718 alloy & Grinding & Wet, MQL & $\begin{array}{l}\text { Nanofluid-aided sunflower oil MQL } \\
\text { lowered grinding energy, coefficient } \\
\text { of friction, and surface roughness } \\
\text { in Inconel } 718 \text { grinding while being } \\
\text { able to effectively clean the machin- } \\
\text { ing area over flooded cooling }\end{array}$ \\
\hline Souza et al. [166] & 7050-T7451 aluminum alloy & Milling & Wet & $\begin{array}{l}\text { Higher surface quality and lower } \\
\text { active mill force on micromilled } \\
\text { aluminum alloy was obtained under } \\
\text { HOFA vegetable-based oil due to } \\
\text { its superior lubrication performance }\end{array}$ \\
\hline Munhoz et al. [165] & 6061-T6 Aluminum, SAE 1045 steel & AFM & Abrasive Flow & $\begin{array}{l}\text { Vegetable oil-based paste reduce } \\
\text { overall surface roughness of } \\
\text { machined material over commercial } \\
\text { paste }\end{array}$ \\
\hline Fernando et al. [167] & AISI 304 stainless steel & Turning & MQL & $\begin{array}{l}\text { Coconut oil improved overall surface } \\
\text { finish and cutting tool wear com- } \\
\text { pared to standard mineral oil }\end{array}$ \\
\hline Khunt et al. [169] & 6063 aluminum alloy & Drilling & Dry, Wet, MQL & $\begin{array}{l}\text { Lowest surface roughness, thrust } \\
\text { force, and torque were obtained } \\
\text { vegetable oil based at higher cutting } \\
\text { speed over commercially available } \\
\text { castor oil }\end{array}$ \\
\hline
\end{tabular}


Table 8 Summary of usage of palm oil as a cutting fluid in machining

\begin{tabular}{|c|c|c|c|c|}
\hline References & Machined material & Machining process & Mode of lubrication & Findings \\
\hline $\begin{array}{l}\text { Rahim and Sasahara } \\
\text { [135] }\end{array}$ & Ti-6Al-4V titanium alloy & Drilling & Dry, MQL & $\begin{array}{l}\text { Palm oil performed better in comparison to } \\
\text { synthetic oil in terms of improving tool life and } \\
\text { cutting temperature. }\end{array}$ \\
\hline Li et al. [183] & GH4169 nickel-based alloy & Grinding & MQL & $\begin{array}{l}\text { Palm oil generated low grinding force and } \\
\text { machining temperature compared to several } \\
\text { other vegetable-based oil. }\end{array}$ \\
\hline Sen et al. [184] & Inconel 690 alloy & Milling & Dry, MQL & $\begin{array}{l}\text { Resultant cutting force, cutting temperature, tool } \\
\text { life, and surface roughness of milled } 690 \text { alloy } \\
\text { were improved substantially under palm oil- } \\
\text { silica-based MQL lubrication compared to dry } \\
\text { milling. }\end{array}$ \\
\hline Bai et al. [80] & Grade 45 steel & Milling & MQL & $\begin{array}{l}\text { Palm oil showed lowest milling force and the best } \\
\text { surface finish in the milling of grade } 45 \text { steel } \\
\text { over synthetic, cottonseed, castor, peanut and } \\
\text { soybean oil. }\end{array}$ \\
\hline Abdollah et al. [181] & Carbon chromium steel & Tribological test & Wet & $\begin{array}{l}\text { HBN-palm oil-blended lubricant showed lower } \\
\text { coefficient of friction compared to commercially } \\
\text { available mineral oil-based lubricants, resulting } \\
\text { in reduced wear rate and smooth steel ball's } \\
\text { surface. }\end{array}$ \\
\hline
\end{tabular}

Availability of data and materials Not applicable as it is a review paper.

Author contribution Gary Wong: formal analysis, investigation, writing-original draft. Sumaiya Islam, Moola Mohal Reddy, Neamul Khandoker, Vincent Lee Chieng Chen: conceptualization, resources, supervision, writing - review and editing, project administration, funding acquisition.

Funding This work was proudly supported by the Malaysian Government through Fundamental Research Grant Scheme (FRGS) grant no. FRGS/ 1/2018/TK03/CURTIN/03/2.

\section{Declarations}

Ethics approval Not applicable as it is a review paper.

Consent to participate On behalf of all authors, the corresponding author agrees to participate as required.

Consent for publication On behalf of all authors, the corresponding author agrees to publish.

Competing interests The authors declare no competing interests.

\section{References}

1. Bruni C, Forcellese A, Gabrielli F, Simoncini M (2006) Effect of the lubrication-cooling technique, insert technology and machine bed material on the workpart surface finish and tool wear in finish turning of AISI 420B. Int J Mach Tools Manuf 46(12):15471554. https://doi.org/10.1016/j.ijmachtools.2005.09.007

2. Liew PJ, Shaaroni A, Sidik NAC, Yan J (2017) An overview of current status of cutting fluids and cooling techniques of turning hard steel. Int J Heat Mass Transf 114:380-394. https://doi.org/ 10.1016/j.ijheatmasstransfer.2017.06.077

3. Salimi-Yasar H, Zeinali Heris S, Shanbedi M (2017) Influence of soluble oil-based $\mathrm{TiO} 2$ nanofluid on heat transfer performance of cutting fluid. Tribol Int 112:147-154. https://doi.org/10.1016/j. triboint.2017.04.004

4. Padmini R, Vamsi Krishna P, Krishna Mohana Rao G (2016) Effectiveness of vegetable oil based nanofluids as potential cutting fluids in turning AISI 1040 steel. Tribol Int 94:490-501. https://doi.org/10.1016/j.triboint.2015.10.006

5. Sharma VS, Dogra M, Suri NM (2009) Cooling techniques for improved productivity in turning. Int J Mach Tools Manuf 49(6):435-453. https://doi.org/10.1016/j.ijmachtools.2008.12. 010

6. An Q, Cai C, Zou F, Liang X, Chen M (2020) Tool wear and machined surface characteristics in side milling Ti6Al4V under dry and supercritical CO2 with MQL conditions. Tribol Int 151:106511. https://doi.org/10.1016/j.triboint.2020.106511

7. Sharma AK, Tiwari AK, Dixit AR (2016) Effects of minimum quantity lubrication (MQL) in machining processes using conventional and nanofluid based cutting fluids: a comprehensive review. J Clean Prod 127:1-18. https://doi.org/10.1016/j.jclep ro.2016.03.146

8. Roy S, Kumar R, Kumar Sahoo A, Kumar Das R (2019) A brief review on effects of conventional and nano particle based machining fluid on machining performance of minimum quantity lubrication machining. Mater Today Proc 18:5421-5431. https://doi.org/10.1016/j.matpr.2019.07.571

9. Balan ASS, Vijayaraghavan L, Krishnamurthy R, Kuppan P, Oyyaravelu R (2016) An experimental assessment on the performance of different lubrication techniques in grinding of Inconel 751. J Adv Res 7(5):709-718. https://doi.org/10. 1016/j.jare.2016.08.002

10. Sakkaki M, Sadegh Moghanlou F, Vajdi M, Pishgar F, Shokouhimehr M, Shahedi Asl M (2019) The effect of thermal contact resistance on the temperature distribution in a WC made cutting tool. Ceram Int 45(17, Part A):22196-22202. https:// doi.org/10.1016/j.ceramint.2019.07.241 
11. Geng D, Lu Z, Yao G, Liu J, Li Z, Zhang D (2017) Cutting temperature and resulting influence on machining performance in rotary ultrasonic elliptical machining of thick CFRP. Int J Mach Tools Manuf 123:160-170. https://doi.org/10.1016/j. ijmachtools.2017.08.008

12. Vishnu AV, Kumar PJ, Ramana MV (2018) Comparison among dry, flooded and MQL conditions in machining of EN 353 steel alloys-an experimental investigation. Mater Today Proc 5(11, Part 3):24954-24962. https://doi.org/10.1016/j.matpr.2018.10. 296

13. Analytical search results for "MQL, Cutting Fluids, Machining, Vegetable Oil" (2021), Scopus (www.scopus.com), Elsevier B.V., Amsterdam, The Netherlands (accessed September $1^{\text {st }}$, 2021).

14. Sreejith PS, Ngoi BKA (2000) Dry machining - machining of the future. J Mater Process Technol 101:289-293. https://doi. org/10.1016/S0924-0136(00)00445-3

15. Ezugwu, C., Okonkwo, U., Sinebe, J., \& Okokpujie, I. (2016). Stability analysis of model regenerative chatter of milling process using first order least square full discretization method.

16. Goindi GS, Sarkar P (2017) Dry machining: a step towards sustainable machining - challenges and future directions. J Clean Prod 165:1557-1571. https://doi.org/10.1016/j.jclepro.2017.07. 235

17. Bermudo C, Trujillo FJ, Herrera M, Sevilla L (2017) Parametric analysis of the ultimate tensile strength in dry machining of UNS A97075 alloy. Proc Manuf 13:81-88. https://doi.org/10.1016/j. promfg.2017.09.012

18. Yang Y-K, Shie J-R, Huang C-H (2006) Optimization of dry machining parameters for high-purity graphite in end-milling process. Mater Manuf Process 21(8):832-837. https://doi.org/ 10.1080/03602550600728141

19. Pattnaik SK, Bhoi NK, Padhi S, Sarangi SK (2018) Dry machining of aluminum for proper selection of cutting tool: tool performance and tool wear. Int J Adv Manuf Technol 98(1):55-65. https://doi.org/10.1007/s00170-017-0307-0

20. Deshpande S, Deshpande Y (2019) A review on cooling systems used in machining processes. Mater Today Proc 18:5019-5031. https://doi.org/10.1016/j.matpr.2019.07.496

21. Galanis, N., Manolakos, D., \& Vaxevanidis, N. (2008). Comparison between dry and wet machining of stainless steel

22. Kerrigan K, Scaife RJ (2018) Wet vs dry CFRP drilling: influence of cutting fluid on tool performance. Proced CIRP 77:315319. https://doi.org/10.1016/j.procir.2018.09.024

23. Songmene V, Zaghbani I, Kientzy G (2018) Machining and machinability of tool steels: effects of lubrication and machining conditions on tool wear and tool life data. Proced CIRP 77:505-508. https://doi.org/10.1016/j.procir.2018.08.252

24. Revuru RS, Zhang JZ, Posinasetti NR (2020) Comparative performance studies of turning 4140 steel with $\mathrm{TiC} / \mathrm{TiCN} /$ TiN-coated carbide inserts using MQL, flooding with vegetable cutting fluids, and dry machining. Int J Adv Manuf Technol 108(1):381-391. https://doi.org/10.1007/s00170-020-05378-8

25. Siva Surya M, Shalini M, Sridhar A (2017) Multi-response optimization on en 19 steel using grey relational analysis through dry \& wet machining. Mater Today Proc 4(2, Part A):2157-2166. https://doi.org/10.1016/j.matpr.2017.02.062

26. Diniz AE, Micaroni R (2007) Influence of the direction and flow rate of the cutting fluid on tool life in turning process of AISI 1045 steel. Int J Mach Tools Manuf 47(2):247-254. https://doi. org/10.1016/j.ijmachtools.2006.04.003

27. Ravi S, Pradeep Kumar M (2011) Experimental investigations on cryogenic cooling by liquid nitrogen in the end milling of hardened steel. Cryogenics 51(9):509-515. https://doi.org/10. 1016/j.cryogenics.2011.06.006
28. Butola R, Jitendrakumar V, Ali P, Khanna V (2017) Effect on surface properties of mild steel during dry turning \& wet turning on lathe. Mater Today Proc 4(8):7892-7902. https://doi.org/10. 1016/j.matpr.2017.07.125

29. Okokpujie IP, Bolu CA, Ohunakin OS, Akinlabi ET, Adelekan DS (2019) A review of recent application of machining techniques, based on the phenomena of CNC machining operations. Proc Manuf 35:1054-1060. https://doi.org/10.1016/j.promfg. 2019.06.056

30. Sankar MR, Choudhury SK (2015) Experimental study and modeling of machining with dry compressed air, flood and minimum quantity cutting fluid cooling techniques. Proced CIRP 31:228233. https://doi.org/10.1016/j.procir.2015.04.089

31. Senevirathne SWMAI, Punchihewa HKG (2017) Comparison of tool life and surface roughness with MQL, flood cooling, and dry cutting conditions with P20 and D2 steel. IOP Conf Ser Mater Sci Eng 244:012006. https://doi.org/10.1088/1757-899x/244/1/ 012006

32. Peng R, Jiang H, Tang X, Huang X, Xu Y, Hu Y (2019) Design and performance of an internal-cooling turning tool with micro-channel structures. J Manuf Process 45:690-701. https://doi.org/10.1016/j.jmapro.2019.08.011

33. Chen B, Xiong F, Tang H, He L, Hu S (2020) Effect of cooling method on small diameter blind-hole drilling of new $\beta$-type dental Ti-Zr-Nb alloy. J Manuf Process 59:421-431. https:// doi.org/10.1016/j.jmapro.2020.10.013

34. MPSystems (Producer). (2021). Understanding high pressure coolant system. Retrieved from https://www.mp-systems.net/ high-medium-pressure-coolant-systems/benefits-of-hpc-syste $\mathrm{ms} /$

35. Kaynak Y, Gharibi A, Yılmaz U, Köklü U, Aslantaş K (2018) A comparison of flood cooling, minimum quantity lubrication and high pressure coolant on machining and surface integrity of titanium Ti-5553 alloy. J Manuf Process 34:503-512. https://doi. org/10.1016/j.jmapro.2018.06.003

36. Stolf P, Paiva JM, Ahmed YS, Endrino JL, Goel S, Veldhuis SC (2019) The role of high-pressure coolant in the wear characteristics of WC-Co tools during the cutting of Ti-6Al-4V. Wear 440-441:203090. https://doi.org/10.1016/j.wear.2019.203090

37. Tamil Alagan N, Hoier P, Beno T, Klement U, Wretland A (2020) Coolant boiling and cavitation wear - a new tool wear mechanism on WC tools in machining Alloy 718 with high-pressure coolant. Wear 452-453:203284. https://doi.org/10.1016/j.wear. 2020.203284

38. Lu Z, Zhang D, Zhang X, Peng Z (2020) Effects of high-pressure coolant on cutting performance of high-speed ultrasonic vibration cutting titanium alloy. J Mater Process Technol 279:116584. https://doi.org/10.1016/j.jmatprotec.2019.116584

39. Fang Z, Obikawa $T$ (2020) Influence of cutting fluid flow on tool wear in high-pressure coolant turning using a novel internally cooled insert. J Manuf Process 56:1114-1125. https://doi.org/ 10.1016/j.jmapro.2020.05.028

40. Nasr G, Soltantarzeh M, Davoodi B, Hajaliakbari A (2020) Assessment of tool wear mechanisms in high-pressure jetassisted turning process of a nickel-based superalloy. Wear 460461:203454. https://doi.org/10.1016/j.wear.2020.203454

41. Sandeep Reddy AV, Ajay Kumar S, Jagadesh T (2020) The Influence of graphite, MoS2 and Blasocut lubricant on hole and chip geometry during peck drilling of aerospace alloy. Mater Today Proc 24:690-697. https://doi.org/10.1016/j.matpr.2020.04.323

42. Tomala A, Hernandez S, Rodriguez Ripoll M, Badisch E, Prakash B (2014) Tribological performance of some solid lubricants for hot forming through laboratory simulative tests. Tribol Int 74:164-173. https://doi.org/10.1016/j.triboint.2014.02.008

43. Sudheerkumar N, Sammaiah P, Rao KV, Sneha M, Ashok CH (2015) Influence of nano solid lubricant emulsions on surface 
roughness of mild steel when machining on lathe machine. Mater Today Proc 2(9, Part A):4413-4420. https://doi.org/10.1016/j. matpr.2015.10.042

44. Gunda RK, Narala SKR (2016) Tribological studies to analyze the effect of solid lubricant particle size on friction and wear behaviour of Ti-6Al-4V alloy. Surf Coat Technol 308:203-212. https://doi.org/10.1016/j.surfcoat.2016.06.092

45. Tiwari A, Makhesana MA, Patel KM, Mawandiya BK (2020) Experimental investigations on the applicability of solid lubricants in processing of AISI 4140 steel. Mater Today Proc 26:2921-2925. https://doi.org/10.1016/j.matpr.2020.02.603

46. Rahmati B, Sarhan AAD, Sayuti M (2014) Morphology of surface generated by end milling AL6061-T6 using molybdenum disulfide (MoS2) nanolubrication in end milling machining. $\mathbf{J}$ Clean Prod 66:685-691. https://doi.org/10.1016/j.jclepro.2013. 10.048

47. Zalaznik M, Kalin M, Novak S, Jakša G (2016) Effect of the type, size and concentration of solid lubricants on the tribological properties of the polymer PEEK. Wear 364-365:31-39. https:// doi.org/10.1016/j.wear.2016.06.013

48. Sterle L, Kalin M, Pušavec F (2018) Performance evaluation of solid lubricants under machining-like conditions. Proced CIRP 77:401-404. https://doi.org/10.1016/j.procir.2018.08.299

49. Sartori S, Ghiotti A, Bruschi S (2018) Solid lubricant-assisted minimum quantity lubrication and cooling strategies to improve Ti6Al4V machinability in finishing turning. Tribol Int 118:287294. https://doi.org/10.1016/j.triboint.2017.10.010

50. Ravi S, Gurusamy P (2020) Experimental studies on the effect of LN2 cooling on the machining of tool steel. Mater Today Proc 33:3292-3296. https://doi.org/10.1016/j.matpr.2020.04.734

51. Zindani D, Kumar K (2020) A brief review on cryogenics in machining process. SN Appl Sci 2(6):1107. https://doi.org/10. 1007/s42452-020-2899-5

52. Shokrani A, Al-Samarrai I, Newman ST (2019) Hybrid cryogenic MQL for improving tool life in machining of Ti-6Al-4V titanium alloy. J Manuf Process 43:229-243. https://doi.org/10. 1016/j.jmapro.2019.05.006

53. Dhar N, Islam S, Paul S (2006) Wear behavior of uncoated carbide inserts under dry, wet and cryogenic cooling conditions in turning C-60. J Braz Soc Mech Sci Eng 28. https://doi.org/10. 1590/S1678-58782006000200003

54. Biček M, Dumont F, Courbon C, Pušavec F, Rech J, Kopač J (2012) Cryogenic machining as an alternative turning process of normalized and hardened AISI 52100 bearing steel. J Mater Process Technol 212(12):2609-2618. https://doi.org/10.1016/j. jmatprotec.2012.07.022

55. Kaynak Y, Karaca HE, Noebe RD, Jawahir IS (2013) Tool-wear analysis in cryogenic machining of NiTi shape memory alloys: a comparison of tool-wear performance with dry and MQL machining. Wear 306(1):51-63. https://doi.org/10.1016/j.wear. 2013.05.011

56. Shokrani A, Dhokia V, Newman ST (2016) Investigation of the effects of cryogenic machining on surface integrity in CNC end milling of Ti-6Al-4V titanium alloy. J Manuf Process 21:172179. https://doi.org/10.1016/j.jmapro.2015.12.002

57. Jawahir IS, Attia H, Biermann D, Duflou J, Klocke F, Meyer D et al (2016) Cryogenic manufacturing processes. CIRP Ann 65(2):713-736. https://doi.org/10.1016/j.cirp.2016.06.007

58. Khare SK, Agarwal S (2017) Optimization of machining parameters in turning of AISI 4340 steel under cryogenic condition using taguchi technique. Proced CIRP 63:610-614. https://doi. org/10.1016/j.procir.2017.03.166

59. Devaraju A, Kishan V (2018) Influence of cryogenic cooling (liquid nitrogen) on microstructure and mechanical properties of friction stir welded 2014-T6 aluminum alloy. Mater Today Proc
5(1, Part 1):1585-1590. https://doi.org/10.1016/j.matpr.2017.11. 250

60. Sivaiah P, Chakradhar D (2018) Effect of cryogenic coolant on turning performance characteristics during machining of 17-4 PH stainless steel: a comparison with MQL, wet, dry machining. CIRP J Manuf Sci Technol 21:86-96. https://doi.org/10.1016/j. cirpj.2018.02.004

61. Damir A, Sadek A, Attia H (2018) Characterization of machinability and environmental impact of cryogenic turning of Ti-6Al4V. Proced CIRP 69:893-898. https://doi.org/10.1016/j.procir. 2017.11.070

62. Danish M, Ginta TL, Abdul Rani AM, Carou D, Davim JP, Rubaiee S, Ghazali S (2019) Investigation of surface integrity induced on AZ31C magnesium alloy turned under cryogenic and dry conditions. Proc Manuf 41:476-483. https://doi.org/10. 1016/j.promfg.2019.09.035

63. Kumar D, Gururaja S, Jawahir IS (2020) Machinability and surface integrity of adhesively bonded Ti/CFRP/Ti hybrid composite laminates under dry and cryogenic conditions. J Manuf Process 58:1075-1087. https://doi.org/10.1016/j.jmapro.2020. 08.064

64. Fernandes MEP, de Melo ACA, de Oliveira AJ, Chesman C (2020) Hard turning of AISI D6 tool steel under dry, wet and cryogenic conditions: an economic investigation aimed at achieving a sustainable machining approach. Cleaner Eng Technol 1:100022. https://doi.org/10.1016/j.clet.2020.100022

65. Stampfer B, Golda P, Schieß1 R, Maas U, Schulze V (2020) Cryogenic orthogonal turning of Ti-6Al-4V. Int J Adv Manuf Technol 111(1):359-369. https://doi.org/10.1007/s00170-020-06105-z

66. Wang F, Wang Y (2020) Research on milling hole of AFRP based on cryogenic cooling processing. Int J Adv Manuf Technol 106(11-12):5277-5287. https://doi.org/10.1007/ s00170-020-05057-8

67. Ezugwu E, Wang Z (1997) Titanium alloys and their machinability-a review. J Mater Process Technol 68:262-274. https:// doi.org/10.1016/S0924-0136(96)00030-1

68. Garcia MV, Lopes JC, Diniz AE, Rodrigues AR, Volpato RS, Sanchez LE d A et al (2020) Grinding performance of bearing steel using MQL under different dilutions and wheel cleaning for green manufacture. J Clean Prod 257:120376. https://doi.org/10. 1016/j.jclepro.2020.120376

69. Sterle L, Mallipeddi D, Krajnik P, Pušavec F (2020) The influence of single-channel liquid CO2 and MQL delivery on surface integrity in machining of Inconel 718. Proced CIRP 87:164-169. https://doi.org/10.1016/j.procir.2020.02.032

70. Özbek O, Saruhan H (2020) The effect of vibration and cutting zone temperature on surface roughness and tool wear in eco-friendly MQL turning of AISI D2. J Mater Res Technol 9(3):2762-2772. https://doi.org/10.1016/j.jmrt.2020.01.010

71. Tunc LT, Gu Y, Burke MG (2016) Effects of minimal quantity lubrication (MQL) on surface integrity in robotic milling of austenitic stainless steel. Proced CIRP 45:215-218. https://doi.org/ 10.1016/j.procir.2016.02.337

72. Barczak LM, Batako ADL, Morgan MN (2010) A study of plane surface grinding under minimum quantity lubrication (MQL) conditions. Int J Mach Tools Manuf 50(11):977-985. https:// doi.org/10.1016/j.ijmachtools.2010.07.005

73. Fratila D (2009) Evaluation of near-dry machining effects on gear milling process efficiency. J Clean Prod 17(9):839-845. https:// doi.org/10.1016/j.jclepro.2008.12.010

74. Patole PB, Kulkarni VV (2018) Optimization of process parameters based on surface roughness and cutting force in MQL turning of AISI 4340 using nano fluid. Mater Today Proc 5(1, Part 1):104-112. https://doi.org/10.1016/j.matpr.2017.11.060

75. Ekinovic S, Prcanovic H, Begovic E (2015) Investigation of influence of MQL machining parameters on cutting forces during 
MQL turning of carbon steel St52-3. Proc Eng 132:608-614. https://doi.org/10.1016/j.proeng.2015.12.538

76. Tai BL, Stephenson DA, Furness RJ, Shih AJ (2014) Minimum quantity lubrication (MQL) in automotive powertrain machining. Proced CIRP 14:523-528. https://doi.org/10.1016/j.procir.2014. 03.044

77. Kochumman J, Satishkumar S, Dinakaran D, Rao V (2014) Influence of different cooling methods on drill temperature in drilling GFRP. Int J Adv Manuf Technol 76:609-621. https://doi.org/10. 1007/s00170-014-6280-y

78. Dhar NR, Islam MW, Islam S, Mithu MAH (2006) The influence of minimum quantity of lubrication (MQL) on cutting temperature, chip and dimensional accuracy in turning AISI-1040 steel. J Mater Process Technol 171(1):93-99. https://doi.org/10.1016/j. jmatprotec.2005.06.047

79. Rahim EA, Dorairaju H (2018) Evaluation of mist flow characteristic and performance in minimum quantity lubrication (MQL) machining. Measurement 123:213-225. https://doi.org/10.1016/j. measurement.2018.03.015

80. Bai X, Zhou F, Li C, Dong L, Lv X, Yin Q (2020) Physicochemical properties of degradable vegetable-based oils on minimum quantity lubrication milling. Int J Adv Manuf Technol 106(910):4143-4155. https://doi.org/10.1007/s00170-019-04695-x

81. Saberi A, Rahimi AR, Parsa H, Ashrafijou M, Rabiei F (2016) Improvement of surface grinding process performance of CK45 soft steel by minimum quantity lubrication (MQL) technique using compressed cold air jet from vortex tube. J Clean Prod 131:728-738. https://doi.org/10.1016/j.jclepro.2016.04.104

82. Iturbe A, Hormaetxe E, Garay A, Arrazola PJ (2016) Surface integrity analysis when machining Inconel 718 with conventional and cryogenic cooling. Proced CIRP 45:67-70. https://doi.org/ 10.1016/j.procir.2016.02.095

83. Pusavec F, Krajnik P, Kopac J (2010) Transitioning to sustainable production - part I: application on machining technologies. J Clean Prod 18(2):174-184. https://doi.org/10.1016/j.jclepro. 2009.08.010

84. Zaman PB, Dhar NR (2019) Design and evaluation of an embedded double jet nozzle for MQL delivery intending machinability improvement in turning operation. J Manuf Process 44:179-196. https://doi.org/10.1016/j.jmapro.2019.05.047

85. Park K-H, Olortegui-Yume J, Yoon M-C, Kwon P (2010) A study on droplets and their distribution for minimum quantity lubrication (MQL). Int J Mach Tools Manuf 50(9):824-833. https://doi. org/10.1016/j.ijmachtools.2010.05.001

86. Abdul Sani AS, Rahim EA, Sharif S, Sasahara H (2019) Machining performance of vegetable oil with phosphonium- and ammonium-based ionic liquids via MQL technique. J Clean Prod 209:947-964. https://doi.org/10.1016/j.jclepro.2018.10.317

87. Hadad M, Sadeghi B (2013) Minimum quantity lubricationMQL turning of AISI 4140 steel alloy. J Clean Prod 54:332-343. https://doi.org/10.1016/j.jclepro.2013.05.011

88. Paturi UMR, Maddu YR, Maruri RR, Narala SKR (2016) Measurement and analysis of surface roughness in WS2 solid lubricant assisted minimum quantity lubrication (MQL) turning of Inconel 718. Proced CIRP 40:138-143. https://doi.org/10.1016/j.procir. 2016.01.082

89. Sarıkaya M, Güllü A (2014) Taguchi design and response surface methodology based analysis of machining parameters in CNC turning under MQL. J Clean Prod 65:604-616. https://doi.org/ 10.1016/j.jclepro.2013.08.040

90. Guerra AJ, Ciurana J (2019) Minimum quantity lubrication in fibre laser processing for permanent stents manufacturing. Proc Manuf 41:492-499. https://doi.org/10.1016/j.promfg.2019.09. 036

91. Tai B, Stephenson D, Furness R, Shih A (2017) Minimum quantity lubrication for sustainable machining. In: Abraham MA (ed)
Encyclopedia of sustainable technologies. Elsevier, Oxford, pp 477-485

92. Kirkhorn L, Gutnichenko O, Bihagen S, Ståhl J-E (2018) Minimum quantity lubrication (MQL) with carbon nanostructured additives in sheet metal forming. Proc Manuf 25:375-381. https://doi.org/10.1016/j.promfg.2018.06.106

93. Esmaeili H, Adibi H, Rezaei SM (2019) An efficient strategy for grinding carbon fiber-reinforced silicon carbide composite using minimum quantity lubricant. Ceram Int 45(8):10852-10864. https://doi.org/10.1016/j.ceramint.2019.02.163

94. Stephenson DA, Hughey E, Hasham AA (2019) Air flow and chip removal in minimum quantity lubrication drilling. Proc Manuf 34:335-342. https://doi.org/10.1016/j.promfg.2019.06.171

95. Qin X, Liu W, Li S, Tong W, Ji X, Meng F et al (2019) A comparative study between internal spray cooling and conventional external cooling in drilling of Inconel 718. Int J Adv Manuf Technol 104(9):4581-4592. https://doi.org/10.1007/ s00170-019-04330-9

96. Dhar NR, Ahmed MT, Islam S (2007) An experimental investigation on effect of minimum quantity lubrication in machining AISI 1040 steel. Int J Mach Tools Manuf 47(5):748-753. https://doi. org/10.1016/j.ijmachtools.2006.09.017

97. Shukla A, Kotwani A, Unune DR (2020) Performance comparison of dry, flood and vegetable oil based minimum quantity lubrication environments during CNC milling of aluminium 6061. Mater Today Proc 21:1483-1488. https://doi.org/10.1016/j. matpr.2019.11.060

98. Niketh S, Samuel GL (2018) Drilling performance of micro textured tools under dry, wet and MQL condition. J Manuf Process 32:254-268. https://doi.org/10.1016/j.jmapro.2018.02.012

99. Chinchanikar S, Choudhury SK (2014) Hard turning using HiPIMS-coated carbide tools: wear behavior under dry and minimum quantity lubrication (MQL). Measurement 55:536-548. https://doi.org/10.1016/j.measurement.2014.06.002

100. Naresh Babu M, Anandan V, Muthukrishnan N, Santhanakumar M (2019) End milling of AISI 304 steel using minimum quantity lubrication. Measurement 138:681-689. https://doi.org/10. 1016/j.measurement.2019.01.064

101. Bonfá MM, Costa DS, Sales WF, Amorim FL, Maia LHA, Machado LR (2019) Evaluation of tool life and workpiece surface roughness in turning of AISI D6 hardened steel using PCBN tools and minimum quantity of lubricant (MQL) applied at different directions. Int J Adv Manuf Technol 103(1-4):971-984. https://doi.org/10.1007/s00170-019-03619-z

102. Muaz M, Choudhury SK (2019) Experimental investigations and multi-objective optimization of MQL-assisted milling process for finishing of AISI 4340 steel. Measurement 138:557-569. https:// doi.org/10.1016/j.measurement.2019.02.048

103. Tomaz IV, Pardal JM, Fonseca MC (2019) Influence of minimum quantity lubrication in the surface quality of milled maraging steel. Int J Adv Manuf Technol 104(9):4301-4311. https://doi. org/10.1007/s00170-019-04262-4

104. Mishra RR, Sahoo AK, Panda A, Kumar R, Das D, Routara BC (2020) MQL machining of high strength steel: a case study on surface quality characteristic. Mater Today Proc 26:2616-2618. https://doi.org/10.1016/j.matpr.2020.02.552

105. Praveen B, Mohan Reddy NM, Akshay Kumar Y, Subash R (2021) Investigating the effect of minimum quantity lubrication on surface finish of EN 47 steel material. Mater Today Proc 38:3253-3257. https://doi.org/10.1016/j.matpr.2020.09.728

106. Choudhury, S., \& Dhar, N. (2008). Effect of minimum quantity of lubricant on tool wear and job dimension and finish in turning AISI 4140 steel.

107. Saha S, Deb S, Bandyopadhyay PP (2020) An analytical approach to assess the variation of lubricant supply to the cutting tool during MQL assisted high speed micromilling. J Mater Process 
Technol 285:116783. https://doi.org/10.1016/j.jmatprotec.2020. 116783

108. Uysal A, Demiren F, Altan E (2015) Applying minimum quantity lubrication (MQL) method on milling of martensitic stainless steel by using nano MoS2 reinforced vegetable cutting fluid. Procedia Soc Behav Sci 195:2742-2747. https://doi.org/10.1016/j. sbspro.2015.06.384

109. Gupta A, Kumar R, Kumar H, Garg H (2020) Comparative performance of pure vegetable oil and $\mathrm{Al} 2 \mathrm{O} 3$ based vegetable oil during MQL turning of AISI 4130. Mater Today Proc 28:16621666. https://doi.org/10.1016/j.matpr.2020.05.019

110. Kedare SB, Borse DR, Shahane PT (2014) Effect of minimum quantity lubrication (MQL) on surface roughness of mild steel of $15 \mathrm{HRC}$ on universal milling machine. Procedia Mater Sci 6:150-153. https://doi.org/10.1016/j.mspro.2014.07.018

111. Lai Z, Wang C, Zheng L, Huang W, Yang J, Guo G, Xiong W (2020) Adaptability of AlTiN-based coated tools with green cutting technologies in sustainable machining of $316 \mathrm{~L}$ stainless steel. Tribol Int 148:106300. https://doi.org/10.1016/j.triboint. 2020.106300

112. Sreejith PS (2008) Machining of 6061 aluminium alloy with MQL, dry and flooded lubricant conditions. Mater Lett 62(2):276-278. https://doi.org/10.1016/j.matlet.2007.05.019

113. Biermann D, Iovkov I, Blum H, Rademacher A, Taebi K, Suttmeier FT, Klein N (2012) Thermal aspects in deep hole drilling of aluminium cast alloy using twist drills and MQL. Proced CIRP 3:245-250. https://doi.org/10.1016/j.procir.2012.07.043

114. Chatha SS, Pal A, Singh T (2016) Performance evaluation of aluminium 6063 drilling under the influence of nanofluid minimum quantity lubrication. J Clean Prod 137:537-545. https://doi.org/ 10.1016/j.jclepro.2016.07.139

115. Islam S, Khandoker N, Izham M, Azizi T, Debnath S (2017) Development of a low cost MQL setup for turning operations. MATEC Web Conf 95:10004. https://doi.org/10.1051/matecconf/ 20179510004

116. Kannan C, Varun Chaitanya CH, Padala D, Reddy L, Ramanujam R, Balan ASS (2020) Machinability studies on aluminium matrix nanocomposite under the influence of MQL. Materials Today: Proceedings, 22, 1507-1516. https://doi.org/10.1016/j.matpr. 2020.02.068

117. Zhu Z, He B, Chen J (2020) Evaluation of tool temperature distribution in MQL drilling of aluminum 2024-T351. J Manuf Process 56:757-765. https://doi.org/10.1016/j.jmapro.2020.05. 029

118. Abas M, Sayd L, Akhtar R, Khalid QS, Khan AM, Pruncu CI (2020) Optimization of machining parameters of aluminum alloy 6026-T9 under MQL-assisted turning process. J Mater Res Technol 9(5):10916-10940. https://doi.org/10.1016/j.jmrt.2020.07. 071

119. Cagan SC, Venkatesh B, Buldum BB (2020) Investigation of surface roughness and chip morphology of aluminum alloy in dry and minimum quantity lubrication machining. Mater Today Proc 27:1122-1126. https://doi.org/10.1016/j.matpr.2020.01.547

120. Javidikia M, Sadeghifar M, Songmene V, Jahazi M (2020) Effect of turning environments and parameters on surface integrity of AA6061-T6: experimental analysis, predictive modeling, and multi-criteria optimization. Int J Adv Manuf Technol 110(910):2669-2683. https://doi.org/10.1007/s00170-020-06027-w

121. Braga DU, Diniz AE, Miranda GWA, Coppini NL (2002) Using a minimum quantity of lubricant (MQL) and a diamond coated tool in the drilling of aluminum-silicon alloys. J Mater Process Technol 122(1):127-138. https://doi.org/10.1016/S0924-0136(01) 01249-3

122. Khan MMA, Mithu MAH, Dhar NR (2009) Effects of minimum quantity lubrication on turning AISI 9310 alloy steel using vegetable oil-based cutting fluid. J Mater Process Technol
209(15):5573-5583. https://doi.org/10.1016/j.jmatprotec.2009. 05.014

123. Joshi KK, Kumar R, Anurag (2018) An experimental investigations in turning of Incoloy 800 in dry, MQL and flood cooling conditions. Proc Manuf 20:350-357. https://doi.org/10.1016/j. promfg.2018.02.051

124. Gutnichenko O, Bushlya V, Bihagen S, Ståhl J-E (2018) Influence of $\mathrm{GnP}$ additive to vegetable oil on machining performance when MQL-assisted turning Alloy 718. Proc Manuf 25:330-337. https://doi.org/10.1016/j.promfg.2018.06.091

125. de Oliveira D, Gomes MC, da Silva MB (2020) Influence of cutting fluid application frequency on the surface quality of micromilled slots on Inconel 718 alloy. Proc Manuf 48:553-558. https://doi.org/10.1016/j.promfg.2020.05.082

126. Nagaraj A, Uysal A, Jawahir IS (2020) An Investigation of process performance when drilling carbon fiber reinforced polymer (CFRP) composite under dry, cryogenic and MQL environments. Proc Manuf 43:551-558. https://doi.org/10. 1016/j.promfg.2020.02.165

127. Yıldırım ÇV, Kıvak T, Sarıkaya M, Şirin Ş (2020) Evaluation of tool wear, surface roughness/topography and chip morphology when machining of Ni-based alloy 625 under MQL, cryogenic cooling and cryoMQL. J Mater Res Technol 9(2):20792092. https://doi.org/10.1016/j.jmrt.2019.12.069

128. Ni C, Zhu L (2020) Investigation on machining characteristics of TC4 alloy by simultaneous application of ultrasonic vibration assisted milling (UVAM) and economical-environmental MQL technology. J Mater Process Technol 278:116518. https:// doi.org/10.1016/j.jmatprotec.2019.116518

129. Zahoor S, Abdul-Kader W, Ishfaq K (2020) Sustainability assessment of cutting fluids for flooded approach through a comparative surface integrity evaluation of IN718. Int J Adv Manuf Technol 111(1):383-395. https://doi.org/10.1007/ s00170-020-06130-y

130. Kaynak Y, Robertson SW, Karaca HE, Jawahir IS (2015) Progressive tool-wear in machining of room-temperature austenitic NiTi alloys: the influence of cooling/lubricating, melting, and heat treatment conditions. J Mater Process Technol 215:95-104. https://doi.org/10.1016/j.jmatprotec.2014.07.015

131. Najiha MS, Rahman MM, Kadirgama K (2016) Performance of water-based $\mathrm{TiO} 2$ nanofluid during the minimum quantity lubrication machining of aluminium alloy, AA6061-T6. J Clean Prod 135:1623-1636. https://doi.org/10.1016/j.jclepro.2015.12.015

132. Marques A, Guimarães C, da Silva RB, da Penha Cindra Fonseca M, Sales WF, Machado ÁR (2016) Surface integrity analysis of Inconel 718 after turning with different solid lubricants dispersed in neat oil delivered by MQL. Proc Manuf 5:609-620. https://doi. org/10.1016/j.promfg.2016.08.050

133. Zhang Y, Li C, Jia D, Li B, Wang Y, Yang M et al (2016) Experimental study on the effect of nanoparticle concentration on the lubricating property of nanofluids for MQL grinding of Ni-based alloy. J Mater Process Technol 232:100-115. https://doi.org/10. 1016/j.jmatprotec.2016.01.031

134. Viswanathan R, Ramesh S, Subburam V (2018) Measurement and optimization of performance characteristics in turning of $\mathrm{Mg}$ alloy under dry and MQL conditions. Measurement 120:107113. https://doi.org/10.1016/j.measurement.2018.02.018

135. Rahim EA, Sasahara H (2011) A study of the effect of palm oil as MQL lubricant on high speed drilling of titanium alloys. Tribol Int 44(3):309-317. https://doi.org/10.1016/j.triboint.2010.10.032

136. Le Coz G, Marinescu M, Devillez A, Dudzinski D, Velnom L (2012) Measuring temperature of rotating cutting tools: application to MQL drilling and dry milling of aerospace alloys. Appl Therm Eng 36:434-441. https://doi.org/10.1016/j.appltherma leng.2011.10.060 
137. Ni C, Zhu L, Yang Z (2019) Comparative investigation of tool wear mechanism and corresponding machined surface characterization in feed-direction ultrasonic vibration assisted milling of Ti-6Al-4V from dynamic view. Wear 436-437:203006. https:// doi.org/10.1016/j.wear.2019.203006

138. Davis B, Schueller JK, Huang Y (2015) Study of ionic liquid as effective additive for minimum quantity lubrication during titanium machining. Manuf Lett 5:1-6. https://doi.org/10.1016/j. mfglet.2015.04.001

139. Venkata Ramana M (2017) Optimization and influence of process parameters on surface roughness in turning of titanium alloy under different lubricant conditions. Mater Today Proc 4(8):8328-8335. https://doi.org/10.1016/j.matpr.2017.07.176

140. Qin S, Li Z, Guo G, An Q, Chen M, Ming W (2016) Analysis of minimum quantity lubrication (MQL) for different coating tools during turning of TC11 titanium alloy. Materials 9. https://doi. org/10.3390/ma9100804

141. Khatri A, Jahan MP (2018) Investigating tool wear mechanisms in machining of Ti-6Al-4V in flood coolant, dry and MQL conditions. Proc Manuf 26:434-445. https://doi.org/10.1016/j.promfg. 2018.07.051

142. Rahman SS, Ashraf MZI, Amin AKMN, Bashar MS, Ashik MFK, Kamruzzaman M (2019) Tuning nanofluids for improved lubrication performance in turning biomedical grade titanium alloy. J Clean Prod 206:180-196. https://doi.org/10.1016/j.jclep ro.2018.09.150

143. da Silva LR, da Silva OS, dos Santos FV, Duarte FJ, Veloso GV (2019) Wear mechanisms of cutting tools in high-speed turning of Ti6Al4V alloy. Int J Adv Manuf Technol 103(1-4):37-48. https://doi.org/10.1007/s00170-019-03519-2

144. Xu J, Ji M, Chen M, el Mansori M (2020) Experimental investigation on drilling machinability and hole quality of CFRP/ Ti6A14V stacks under different cooling conditions. Int J Adv Manuf Technol 109(5-6):1527-1539. https://doi.org/10.1007/ s00170-020-05742-8

145. Khaliq W, Zhang C, Jamil M, Khan AM (2020) Tool wear, surface quality, and residual stresses analysis of micro-machined additive manufactured Ti-6Al-4V under dry and MQL conditions. Tribol Int 151:106408. https://doi.org/10.1016/j.triboint. 2020.106408

146. Liu N, Zou X, Yuan J, Wu S, Chen Y (2020) Performance evaluation of castor oil-ethanol blended coolant under minimum quantity lubrication turning of difficult-to-machine materials. J Manuf Process 58:1-10. https://doi.org/10.1016/j.jmapro.2020.07.058

147. Raina A, Anand A (2018) Lubrication performance of synthetic oil mixed with diamond nanoparticles: effect of concentration. Mater Today Proc 5(9, Part 3):20588-20594. https://doi.org/10. 1016/j.matpr.2018.06.438

148. Lopes JC, Ventura CEH, de Fernandes L, Tavares AB, LEA S, de Mello HJ et al (2019) Application of a wheel cleaning system during grinding of alumina with minimum quantity lubrication. Int J Adv Manuf Technol 102(1):333-341. https://doi.org/10. 1007/s00170-018-3174-4

149. De Oliveira D, Da ds, R. B., \& Gelamo, R. V. (2019) Influence of multilayer graphene platelet concentration dispersed in semisynthetic oil on the grinding performance of Inconel 718 alloy under various machining conditions. Wear 426-427:1371-1383. https://doi.org/10.1016/j.wear.2019.01.114

150. Rajeshkumar N, Ramesh S (2020) Design \& optimization of machining parameters of minimum quantity lubrication in milling of Ti-6Al-4V. Mater Today Proc. https://doi.org/10.1016/j. matpr.2020.10.474

151. de Moraes DL, Garcia MV, Lopes JC, Ribeiro FSF, de Angelo Sanchez LE, Foschini CR, de Mello HJ, Aguiar PR, Bianchi EC (2019) Performance of SAE 52100 steel grinding using MQL technique with pure and diluted oil. Int J Adv
Manuf Technol 105(10):4211-4223. https://doi.org/10.1007/ s00170-019-04582-5

152. Shashidhara YM, Jayaram SR (2010) Vegetable oils as a potential cutting fluid-an evolution. Tribol Int 43(5):1073-1081. https:// doi.org/10.1016/j.triboint.2009.12.065

153. Ozcelik B, Kuram E, Huseyin Cetin M, Demirbas E (2011) Experimental investigations of vegetable based cutting fluids with extreme pressure during turning of AISI 304L. Tribol Int 44(12):1864-1871. https://doi.org/10.1016/j.triboint.2011.07. 012

154. Debnath S, Reddy MM, Yi QS (2014) Environmental friendly cutting fluids and cooling techniques in machining: a review. J Clean Prod 83:33-47. https://doi.org/10.1016/j.jclepro.2014.07. 071

155. Davoodi B, Tazehkandi AH (2014) Experimental investigation and optimization of cutting parameters in dry and wet machining of aluminum alloy 5083 in order to remove cutting fluid. J Clean Prod 68:234-242. https://doi.org/10.1016/j.jclepro.2013.12.056

156. Aydin, S. (2017). Application of quantitative real-time PCR for microbial community analysis in environmental research

157. Wakabayashi T, Suda S, Inasaki I, Terasaka K, Musha Y, Toda Y (2007) Tribological action and cutting performance of MQL media in machining of aluminum. CIRP Ann 56(1):97-100. https://doi.org/10.1016/j.cirp.2007.05.025

158. Kamata Y, Obikawa T (2007) High speed MQL finish-turning of Inconel 718 with different coated tools. J Mater Process Technol 192-193:281-286. https://doi.org/10.1016/j.jmatprotec.2007.04. 052

159. Mahadi MA, Choudhury IA, Azuddin M, Nukman Y (2017) Use of boric acid powder aided vegetable oil lubricant in turning AISI 431 steel. Proc Eng 184:128-136. https://doi.org/10.1016/j. proeng.2017.04.077

160. Agrawal SM, Patil NG (2018) Experimental study of non edible vegetable oil as a cutting fluid in machining of M2 Steel using MQL. Proc Manuf 20:207-212. https://doi.org/10.1016/j.promfg. 2018.02.030

161. Ghatge DA, Ramanujam R, Reddy BS, Vignesh M (2018) Improvement of machinability using eco-friendly cutting oil in turning duplex stainless steel. Mater Today Proc 5(5, Part 2):12303-12310. https://doi.org/10.1016/j.matpr.2018.02.208

162. Singh H, Sharma VS, Singh S, Dogra M (2019) Nanofluids assisted environmental friendly lubricating strategies for the surface grinding of titanium alloy: Ti6Al4V-ELI. J Manuf Process 39:241-249. https://doi.org/10.1016/j.jmapro.2019.02.004

163. Singaravel B, Shekar KC, Reddy GG, Prasad SD (2020) Experimental investigation of vegetable oil as dielectric fluid in Electric discharge machining of Ti-6Al-4V. Ain Shams Eng J 11(1):143147. https://doi.org/10.1016/j.asej.2019.07.010

164. Awale AS, Vashista M, Khan Yusufzai MZ (2020) Multi-objective optimization of MQL mist parameters for eco-friendly grinding. J Manuf Process 56:75-86. https://doi.org/10.1016/j.jmapro. 2020.04.069

165. Munhoz MR, Dias LG, Breganon R, Ribeiro FSF, de Souza Gonçalves JF, Hashimoto EM, da Silva Júnior CE (2020) Analysis of the surface roughness obtained by the abrasive flow machining process using an abrasive paste with oiticica oil. Int $\mathbf{J}$ Adv Manuf Technol 106(11-12):5061-5070. https://doi.org/10.1007/ s00170-019-04920-7

166. Chanes De Souza M, Wiesner HM, Kuche Y, Polte J, de Oliveira Gomes J, Uhlmann E (2019) Influence of the fatty acid profile on the lubricating film formation in micro-milling process on 7050-T7451 aluminum alloy. Int J Adv Manuf Technol 106(12):233-241. https://doi.org/10.1007/s00170-019-04625-x

167. Fernando WLR, Sarmilan N, Wickramasinghe KC, Herath HMCM, Perera GIP (2020) Experimental investigation of minimum quantity lubrication (MQL) of coconut oil based metal 
working fluid. Mater Today Proc 23:23-26. https://doi.org/10. 1016/j.matpr.2019.06.079

168. Lal Virdi R, Singh Chatha S, Singh H (2020) Performance evaluation of Inconel 718 under vegetable oils based nanofluids using minimum quantity lubrication grinding. Mater Today Proc 33:1538-1545. https://doi.org/10.1016/j.matpr.2020.03.802

169. Khunt CP, Makhesana MA, Patel KM, Mawandiya BK (2020) Performance assessment of vegetable oil-based minimum quantity lubrication (MQL) in drilling. Mater Today Proc. https://doi. org/10.1016/j.matpr.2020.09.741

170. Deiab I, Raza SW, Pervaiz S (2014) Analysis of lubrication strategies for sustainable machining during turning of titanium Ti-6Al-4V alloy. Proced CIRP 17:766-771. https://doi.org/10. 1016/j.procir.2014.01.112

171. Rao CM, Rao SS, Herbert MA (2018) Development of novel cutting tool with a micro-hole pattern on PCD insert in machining of titanium alloy. J Manuf Process 36:93-103. https://doi.org/10. 1016/j.jmapro.2018.09.028

172. Gaurav G, Sharma A, Dangayach GS, Meena ML (2020) Assessment of jojoba as a pure and nano-fluid base oil in minimum quantity lubrication (MQL) hard-turning of Ti-6Al-4V: a step towards sustainable machining. J Clean Prod 272:122553. https:// doi.org/10.1016/j.jclepro.2020.122553

173. Loh SK (2017) The potential of the Malaysian oil palm biomass as a renewable energy source. Energy Convers Manag 141:285298. https://doi.org/10.1016/j.enconman.2016.08.081

174. Umar MS, Urmee T, Jennings P (2018) A policy framework and industry roadmap model for sustainable oil palm biomass electricity generation in Malaysia. Renew Energy 128:275-284. https://doi.org/10.1016/j.renene.2017.12.060

175. Tan C-P, Nehdi IA (2012) 13 - the physicochemical properties of palm oil and its components. In: Lai O-M, Tan C-P, Akoh CC (eds) Palm oil. AOCS Press, pp 377-391

176. Monthly Palm Oil Trade Statistics 2020. (2021). Malaysian Palm Oil Council. http://mpoc.org.my/monthly-palm-oil-trade-stati stics-2020/

177. Masjuki HH, Maleque MA, Kubo A, Nonaka T (1999) Palm oil and mineral oil based lubricants- their tribological and emission performance. Tribol Int 32(6):305-314. https://doi.org/10.1016/ S0301-679X(99)00052-3
178. Syahrullail S, Zubil BM, Azwadi CSN, Ridzuan MJM (2011) Experimental evaluation of palm oil as lubricant in cold forward extrusion process. Int J Mech Sci 53(7):549-555. https://doi.org/ 10.1016/j.ijmecsci.2011.05.002

179. Razak DM, Syahrullail S, Yahya A, Mahmud N, Hashim NLS, Nugroho K (2013) Lubrication on the curve surface structure using palm oil and mineral oil. Proc Eng 68:607-612. https:// doi.org/10.1016/j.proeng.2013.12.228

180. Shomchoam B, Yoosuk B (2014) Eco-friendly lubricant by partial hydrogenation of palm oil over $\mathrm{Pd} / \gamma-\mathrm{Al} 2 \mathrm{O} 3$ catalyst. Ind Crop Prod 62:395-399. https://doi.org/10.1016/j.indcrop.2014. 09.022

181. Abdollah MFB, Amiruddin H, Jamallulil AD (2020) Experimental analysis of tribological performance of palm oil blended with hexagonal boron nitride nanoparticles as an environment-friendly lubricant. Int J Adv Manuf Technol 106(9-10):4183-4191. https://doi.org/10.1007/s00170-019-04906-5

182. Wang Y, Li C, Zhang Y, Li B, Yang M, Zhang X et al (2017) Comparative evaluation of the lubricating properties of vegetable-oil-based nanofluids between frictional test and grinding experiment. J Manuf Process 26:94-104. https://doi.org/10. 1016/j.jmapro.2017.02.001

183. Li B, Li C, Zhang Y, Wang Y, Jia D, Yang M (2016) Grinding temperature and energy ratio coefficient in MQL grinding of high-temperature nickel-base alloy by using different vegetable oils as base oil. Chin J Aeronaut 29(4):1084-1095. https://doi. org/10.1016/j.cja.2015.10.012

184. Sen B, Mia M, Mandal UK, Mondal SP (2020) Synergistic effect of silica and pure palm oil on the machining performances of Inconel 690: a study for promoting minimum quantity nano doped-green lubricants. J Clean Prod 258:120755. https://doi. org/10.1016/j.jclepro.2020.120755

185. Sen B, Gupta MK, Mia M, Mandal UK, Mondal SP (2020) Wear behaviour of TiAlN coated solid carbide end-mill under alumina enriched minimum quantity palm oil-based lubricating condition. Tribol Int 148:106310. https://doi.org/10.1016/j.triboint.2020. 106310

Publisher's note Springer Nature remains neutral with regard to jurisdictional claims in published maps and institutional affiliations. 